








\section{CHRISTIANITY AND THE SOCIAL ORDER}




\section{Digitized by the Internet Archive in 2007 with funding from Microsoft Corporation}


CHRISTIANITY AND THE SOCIAL ORDER 


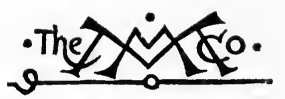

\section{THE MACMILLAN COMPANY NEW YORK - BOSTON - CHICAGO ATLANTA - SAN FRANCISCO}

MACMILLAN \& CO., Limited LONDON - BOMBAY - CALCUTTA MELBOURNE

THE MACMILLAN CO. OF CANADA, Lrd. TORONTO 


\section{CHRISTIANITY AND THE SOCIAL ORDER}

BY

R. J. CAMPBELL, M.A. MINISTER OF THE CITY TEMPLE, LONDON AUTHOR OF "THE NEW THEOLOGY," "NEW THEOLOGY SERMONS," ETC.

\section{Jow 19 ark \\ THE MACMILLAN COMPANY 1907}

All rights reserved 


\section{$H N^{3 !}$
.$C 2$}

\section{Q $: 9 E$}

COPYRIGHT, r907,

By THE MACMILLAN COMPANY.

Set up and electrotyped. Published December, rgo7.

J. s. Cushing Co. - Berwick \& Smith Co.

Norwood, Mass., U.S.A. 
To the Church and Congregation of the City Temple, in recognition of the loyalty, charity, and liberality of spirit with which they have sustained their minister in his endeavour to present the wider gospel to the time. 



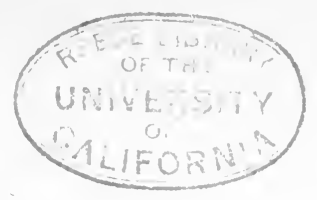

\section{INTRODUCTION}

ThE following pages constitute an attempt to show the correspondence between the principles of Christianity and those of modern Socialism Socialism in the best sense of the term. They are written from the point of view of one who believes that the movement reprobated by the Pope on the one hand, and dogmatic Protestantism on the other, under the name of modernism really represents a return to the primitive Christian evangel, freed from its limitations and illusions. The present writer regards this spiritual movement, for such it is, as destined to rescue the true Christianity from ecclesiasticism in its various forms. In the process it may work the overthrow of the Churches as we have them now - that is, religious organisations held together by dogmatic statements of belief rather than by the perception of a practical end to be-attained. It is herein maintained that the practical end which alone could justify the existence of Churches is the realisation of the Kingdom of God, which only means the reconstruction of society on a basis of mutual helpfulness instead of strife and competition. It may be that the modernist movement will in the long run succeed 
in freeing Christianity from the influences which have obscured or deflected this ideal; or, at any rate, may succeed sufficiently far to remove the distrust which at present exists between many of the leaders of the Socialist movement and the advanced representatives of the Christian religion.

It should be clearly understood that in the task thus attempted I expressly disclaim any intention of denying a place in the Socialist movement to all but the adherents of liberal Christian thought. It is already patent to all the world that the Socialist movement has found room for men as widely divergent in their views of religion as could well be imagined. Some of its most devoted adherents are sacerdotalists, others are avowed materialists; and it would be grossly unfair to exclude either. To deny a place in the Socialist ranks to a veteran like the Rev. Stewart Headlam because he happens to be a sacerdotalist would be a piece of unpardonable effrontery. The one thing which $I$ have tried to keep before me in these pages is the desirability of showing what primitive Christianity set out to realise, and, therefore, how nearly identical were its practical aims with those of modern Socialism. If, in doing so, I have felt obliged to show the unhistorical character of the sacerdotalist position, I have been no less frank in showing the impossibilities and illogicalities of orthodox Protestantism. As a matter of fact, I regard the Catholic idea of a visible universal fellowship as nearer to the spirit 
both of ancient Christianity and modern Socialism than is individualistic Protestantism.

It may not be out of place to say a word as to the way in which I have come to be identified with the Socialist movement. The first and most obvious influence in this direction was the study of Christian origins, which led me gradually but irresistibly to see that the first Christian preachers did not know of any other gospel than that of a universal brotherhood on earth. I have never been anything else than a liberal in theology - all assertions to the contrary notwithstanding - but my way of presenting the truth in the earlier years of my ministry was necessarily less clear and coherent than at present, for it rested too much on the other-worldism of conventional Christian preaching. The realisation that this other-worldism was totally absent from primitive Christian thought forced me, like so many others, upon what was practically the Socialist position without any first-hand acquaintance with the Socialist movement itself. I now regard Socialism as the practical expression of Christian ethics and the evangel of Jesus.

But a further and more immediately effective influence came into existence as follows. In the autumn of 1904 I wrote an article in the National Review on the question of Sunday observance, in which I pointed out certain sinister tendencies of the time, particularly among the working classes. The result was a newspaper storm, in which a 
number of clergy and nonconformist ministers played a discreditable part. Many of them went out of their way to make my strictures the subject of sermons in which they fulsomely praised the working-man and credited him with every imaginable virtue. The object of this kind of sycophantic proceeding was obvious, and, probably for that reason, it did not succeed. I was asked to address a mass meeting of Trades Union representatives, and repeat my observations face to face with the workers themselves and listen to what they had to say in reply. I did so, with the result, on the one hand, that the working-men were able for the first time to hear my actual words instead of garbled newspaper reports and slanderous pulpit versions of them; while, on the other, I realised that, although all I had said was perfectly true, and no one could really deny it, I had not taken account of the working-man's point of view. The strictures were resented, not so much because they were unjust, as because they were made by a man who did not share the privations and disabilities of those with whom he found fault. I determined to do my best to get to see things from the point of view of the unprivileged majority, and I hope I have, to a certain extent, succeeded. Ever since that memorable meeting I have been more or less closely in touch with some of the more prominent leaders of the Labour movement in this country. In the autumn of last year I preached a sermon in the 
City Temple on Christianity and Collectivism, in which I declared myself a Socialist. Forthwith all the Labour platforms were thrown open to me. When the New Theology controversy broke out in January of the present year these were almost the only platforms I had left. All my Free Church Council engagements were cancelled by the Churches themselves, as were most of my preaching appointments with other ecclesiastical organisations. Even where they were not cancelled the situation was, as a rule, to say the least of it, somewhat strained. At the present moment $I$ am in the position of having been quietly excluded from an active share in every Nonconformist organisation with which I was formerly connected, with the exception of the City Temple itself. I do not complain of this; it has done me no harm whatever; but it is as well for the public to know the facts.

I work now in the confident expectation that with the rise of a younger generation of able men in the Churches themselves - men of liberal outlook in religion, and inspired by the social consciousness - I may live to see the time when the Socialist movement, realised from the spiritual point of view, will have laid hold of Nonconformity as it is already laying hold of the Anglican church. The present official heads of Nonconformity cannot expect to boycott a movement for ever by the futile expedient of boycotting this man and that among its representatives. The time will come when the 
wider theology and the Socialist gospel will be seen to be one and the same, and until it does come I offer myself, with all the little power I possess, to the service of every young man who is trying to make his way against the tide of prejudice and obscurantism with which this joint movement is at present assailed. It is but little that one man can do except to help where opportunity affords, in the true spirit of comradeship, the causes that most need helping. One cannot do more, and would not willingly do less. 


\section{CONTENTS}

CHAPTER

PAGE

I. The Churches and the Masses . - . I

II. The Kingdom of God : I. In Jewish History 2 I

III. The Kingdom of God: II. In Primitive Christianity $•$ •

IV. The Kingdom of God: II. In Primitive

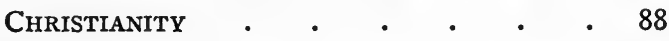

V. The Kingdom of God: III. In Present-day Christianity $•$ •

VI. The Common Objective of Christianity AND SOCIALISM $• \quad \cdot \quad \cdot \quad \cdot \quad \cdot \quad \cdot \quad 147$

VII. The Socialising of Natural Resources - I76 VIII. The Socialising OF INDUSTRY • • - 20 I IX. The Socialised State: I. • • • 23 I X. The Sochalised State: II. • • • . 259 



\section{CHRISTIANITY AND THE SOCIAL ORDER}

\section{CHAPTER I}

\section{THE CHURCHES AND THE MASSES}

The decline of church-going. - We are to-day confronted by the startling fact that in practically every part of Christendom the overwhelming majority of the population is alienated from Christianity as represented by the churches. In our own country nearly seventy-five per cent. of the adult population remains permanently out of touch with organised religion. Broadly speaking, it is true that only a section of the middle class ever attends church at all; the workers, as a body, absent themselves; the professional and upper classes do the same. Not so very long ago, attendance at church was held to be a social necessity, a sort of hall mark of respectability; it is not so now. A professional or business man can be just as sure of success without churchgoing as he can with it; no stigma attaches to abstention. The artisan class not only remains aloof from, but even contemptuous of, churches and preachers; no appeal ever produces so much as a ripple on the surface of their indifference. As soon 
as the children in our Sunday schools reach adolescence they become lost to religious influences, or, at any rate, the male portion of them drifts away. In any ordinary church service women form the overwhelming majority of the worshippers. There are several ways of accounting for this, chief among which is the fact that for the most part women have not yet come to feel, as men must feel, the dissonance between pulpit Christianity and prevailing economic conditions in the modern world. But women are coming to take their place in business and in the professions; and the more this tendency develops, the more certain is it that women will stay away from church as men are doing. Of course it is obvious that, even already, the women who compose the congregations in most places of worship are but a small minority of their sex.

On the Continent this falling away of the people from the churches is more marked than in this country. Educated Germans frequently express their astonishment on coming to England at the fact that so many people go to church. This is a phenomenon to which they are quite unaccustomed at home, and the reason for the difference is fairly simple. In this country the social life of the lower middle classes centres to a considerable extent around the church. The church is the club or public-house, the place to which people must go in order to meet one another and enjoy one another's company. In Germany this is not so; the ordinary centre of 
social life is of quite a different kind, with the consequence that people do not feel any need for the church as a meeting-place. Once let the same set of conditions be established here, and we shall have just the same result; the middle class will do what other classes have already done, they will stay away from church. At present, in many districts the division of classes is plainly marked by the fact that the artisans meet at the alehouse while those a little higher up the social scale meet at church. The vicar of the parish is the head of one social set, and the nonconformist minister of another, but neither of them touches the masses; the workers prefer another kind of club.

The Church as a social centre. - That this is recognised to some extent is evident from the number of devices which have been adopted of late years in order to attract people to church. The institutional church, as it is called, represents the most advanced of these, but every church tries to follow more or less on the same lines. The list of the social activities of any vigorous church in any populous centre to-day is lengthy and elaborate. It is noteworthy that these various organisations are similar to those existing in connection with successful secular institutions of a social or educational character; they are not distinctively religious at all. The discovery has been made by their promoters that something of the kind is imperative if people are to be got into the churches. So we have literary so- 
cieties, gymnasia, swimming clubs, photographic clubs, rambling clubs, tennis and croquet clubs, billiard-rooms, smoking-rooms, restaurants, and a host of others running in connection with church services and religious meetings. It would be foolish to decry them, for they serve a useful purpose, but it is plainly evident that they have sprung into existence in order to supply what will be sought elsewhere if the churches do not rise to the occasion. These things could flourish just as well if there were no religious services whatever associated with them. They are a confession that the churches are ceasing to hold their own. What a surprise Richard Baxter, John Bunyan, or even John Wesley or George Whitefield, would receive if they could behold the institutional church of to-day! I was recently told of a philanthropic and public-spirited employer of labour who erected a number of model dwellings for his workpeople in the neighbourhood of one or two churches (also erected by himself), in the hope that the churches would be well filled and be the means of maintaining a high level of character and conduct in that particular community. There was no public-house in the district to act as counter attraction, but somehow the tenants of those model dwellings did not go to church until the usual club facilities began to be provided; to prayers and sermons they paid no heed.

All this is so well known that some may consider it useless to draw attention to it. But as, 
apparently, there are very few among the ecclesiastical leaders of the day who are willing or able to recognise the root causes of the tendency which everybody admits, it is as well to face the situation before proceeding to examine the whole movement of which this is but a symptom. It is absolutely clear that church-going is on the decline, and that the ordinary gospel preached from the pulpit has no power to influence the public. The curious thing is that religious teachers and administrators should be as well content as they seem to be with this state of things, and should resent so warmly any suggestion that their gospel may be at fault. A fairly prominent theologian stated not long ago, that while he did not deny what was taking place, he was not in the least perturbed by it, for he believed that the Gospel of Christ had never appealed to more than a remnant of the world's total population, and never would. This conviction must have been rather comforting to this particular gentleman, especially as, like so many of his class, he stands on fairly good terms with the world in all ordinary respects. But for the rest of us this consideration is not quite so comforting. If Christianity is a real message to humanity - a message of universal application, and not confined to any one age or clime - it should not be losing its grip to-day, and it is impossible for a lover of mankind to look on with equanimity at the increasing alienation between the churches and the masses. It is pathetic - nay, 
more than pathetic, it is dreadful - to see the churches engaged in strife or competition with one another, while the great world passes by unheeding. It is only too sadly true that very many churches are having a hard fight to keep their heads above water, and that the minister's first aim in every such case is to make a business success of the institution if he can. As often as not, he looks with anything but favour upon the establishment of some other Christian organisation in his immediate neighbourhood, even though it be of the same faith and order as his own. The principle of competition and trade rivalry is as observable here as anywhere else. The religious public is such a limited one that the success of one church means the weakening of another; and it becomes requisite that the minister should be a man who is able to "draw" - that is, draw from other churches - the congregation required to make the business a financial success. Often enough the minister of the church is regarded as a salaried business manager, whose duty it is to see that the balance comes out on the right side at the end of the year, and that the establishment holds its own in public favour. The most saddening feature of this tendency is that it almost compels a minister to lose sight of what should be the main object of his ministry and concentrate instead upon the task of keeping his own footing in the swirl of events. The moment an institution begins to fight for its own existence, rather than 
for the cause it professes to serve, it has forfeited the right to continue. If the number of churches in England, especially Nonconformist churches, of which this is true, were to be closed, there would be a very considerable thinning of the present total. So far as the Church of England is concerned the case is not so very different; but there are endowments to fall back upon.

The humanitarian activities of the churches fail to arrest the decline. - It would not be fair to say that there is not plenty of unselfish religious enthusiasm still at work for far other reasons than that of keeping church doors open. Every one knows of the social redemptive work of the Salvation Army; and there is hardly any religious denomination which has not its representatives serving in the poorer districts of our great cities. It is, perhaps, no injustice to other organisations to say that the High Church party has specially distinguished itself in this way. Nothing could exceed the devotion of some Anglican priests who go and live in the midst of the poor in slum tenements, and make their lives a gift to the service of the suffering and degraded. They believe intensely in their own form of the Christian evangel, and they unite it to a vigorous social propaganda, which is more than some other denominations do. But I am not sure that a great part of this devotion is not waste of energy - a desperate effort to deal with symptoms instead of causes. Every year we pour money and men into 
the slums of London and other great cities, without making any appreciable difference to the vast total of misery and crime engendered therein. The sufferers accept the service, but it would be quite untrue to say that the churches exert any great influence of a distinctly religious kind upon them. Charity demoralises the poor, and gospel missions fail to touch them. There is no blinking the fact that if the churches represent Christianity, then Christianity is rapidly losing its hold in this professedly religious country, as well as in every other country of the civilised world.

And yet the masses not hostile to the religion of Jesus. - How is this to be accounted for? Is it because the average man is hostile to or despises Christianity? Not at all. Of course we hear a great deal of severe criticism of Christianity, as it is popularly understood, but that proves nothing. Christianity, as popularly understood, is not the religion of Jesus. Such publications as those issued by the Rationalist Press Association have an enormous sale, but this points only to the impatience felt by the ordinary sensible man of the world at the assumptions of dogmatic theology. But the great mass of the people takes no account of these things. The ordinary working-man is not hostile to Christianity; he just lets it alone, because it seems to have nothing to do with his life. If he felt that it touched his vital everyday problems, he would either definitely embrace it or definitely reject 
it. He does neither, for the simple reason that, so far as he is able to see, the Christianity he hears about from the pulpit and from church formularies, has little or nothing to do with life as he knows it. Certainly there is no hostility to the name of Jesus. Probably it would be true to say that the name of Jesus receives an intelligent reverence to-day such as it never received before, even in the so-called ages of faith. The Jesus of history has been recovered for us, and has aroused a new interest in the minds of the workers of this country from the purely human and ethical point of view. An examination of a few of the addresses given at men's meetings, Pleasant Sunday Afternoon gatherings, and such-like, would serve to demonstrate this if evidence were needed. No, it is not Christianity as represented in the character and teaching of Jesus which the workers reject, it is the Christianity of the churches.

The Christianity of the churches is not the religion of Jesus. - When I say this, I am far from intending to make an undiscriminating attack upon the churches, quite the contrary. We are living in an age of rapid transition when the churches, as we have known them, are having to adjust themselves to new conditions and new problems, and have not yet realised the urgency of the situation. Religion has always been conservative in tendency, and always will be, because of its primary importance in human life. When a truth has become associated 
with any particular form of statement, men are slow to tamper with the form for fear of losing the truth itself. In proportion to their loyalty to the truth and their experience of its value is their reluctance to part with the form. It is not only Christianity of which this statement holds good; it is true of almost any religion. And yet change is going on all the time. Dogma develops, like everything else in human concerns, and what is called old in doctrinal forms is, as often as not, comparatively modern. In the light of historical criticism nothing is much more untenable than the claim of the Church of Rome to have kept unchanged the faith once for all delivered to the saints. As a matter of fact she has done nothing of the kind, and it was impossible that she should. It has often been said that the best criticism of a dogma is its history, and once we know the history of the development of dogma in the Church of Rome, we know beyond question that Christianity, as represented by the oldest church in Christendom, the church which claims to be the only true representative of apostolic Christianity, is something quite different from the religion of Jesus. It is just the same with Protestantism. There is no church in Christendom to-day which would be recognisable by a Christian of the first century. This is not necessarily to the discredit of the churches. It was inevitable that the Christian society should change its character and modify its tenets as time went on if it was to live at all. What many people 
fail to see is that any change was ever necessary, or that primitive Christianity itself could be less than perfect. Whether we like it or not we shall have to recognise that the Christianity of to-day is not the Christianity of the first century. Whether it is better or worse is not immediately to the point; it is different. We shall have to discuss and admit the difference, and then see whether the Christianity of the churches has forgotten or ignored something which the first Christians knew and taught, and which is as necessary to the world now as it was then.

Here, then, is the plain issue, and the importance of the issue must be my justification for taking up time in stating what everybody already knows perfectly well, and is being pointed out on every hand. It is difficult to see how any one can dispute the fact that the churches are rapidly losing their hold on the modern mind. This would not matter so much were it not for the fact that nothing has as yet taken their place as an uplifting spiritual influence in human experience. I should not regret for a single hour the decline, or even the disappearance of the churches were it not for the fact that to the ordinary man the churches still stand for religion, that is for the higher nature of man in relation to the universal order. Give us something real and effective in place of this and the churches can go. But as yet we have nothing in their place, or nothing which commands universal attention; and the worst of the 
situation is that in abandoning the churches most people think they are dispensing with religion too, whereas it is not necessary to do anything of the sort. This tacit belief is doing incalculable harm, for it hinders men from perceiving that the Spirit of God is at work in the world in ways of which the churches so far have taken very little account. It is this misapprehension which, I am convinced, is responsible for a great part of the so-called materialism of the present day. Men too readily take for granted that Christianity has no message to the age because the churches are not giving it; in the decay of the latter they seem to see the disappearance of the former. In the clever series of articles which appeared in the Clarion some time ago, and were reproduced afterwards in book form under the title "God and my Neighbour," this misapprehension was plainly evident all the way through. The writer took for granted that dogmatic Christianity, as preached in half-empty churches to-day, was Christianity as it came into the world. Many of Mr. Blatchford's critics insisted that he was setting up a man of straw in order to knock it down again, and that Christian doctrine, as he stated it, was not Christian doctrine as held and taught by the enlightened pulpit of our time. It cannot honestly be maintained, however, that Mr. Blatchford was so very far wrong. He only stated in plain language that which is implicit in the conventional pulpit utterances of our time. Few preachers are now prepared 
to say baldly the things they profess to believe about sin and redemption, the person of Christ, death, judgment, heaven, and hell. Most of them feel that dogmatic Christianity is somehow out of touch with the life of to-day, but they are not prepared to break with it. Instead they go on talking vaguely from premises which they suspect to be unsound, and which the ordinary intelligent man of the world would not admit for a moment. It seldom seems to occur either to assailants of Christianity, like the editor of the Clarion, or to the ordinary churchgoer that the Christianity represented by the so-called orthodox churches is not Christianity at all. The Christianity of New Testament times, as I shall presently try to show, did undoubtedly contain elements which the modern mind would reject as unhesitatingly as it rejects the dogmatic Christianity of to-day, but its emphasis was altogether different from the latter. It is this plain, broad fact which needs to be recognised and brought out in the immediate future, and in the recognition of which $I$ see hope for the churches. It is a deplorable thing that so many thousands of our fellow-countrymen should think that in breaking with the churches as the churches now are they are breaking with Christianity. Let them find out what Christianity is, and they will discover that in principle it was at first the very thing which is represented by the movement toward social regeneration to-day.

The rise of Socialism. - In every quarter of the 
civilised world a new spirit is evident amongst the masses of the people. A movement is rising and gathering strength in every nation, a movement of which rulers and legislatures are having to take cognisance. It is the same movement everywhere, and most observers of the signs of the times are now agreed that it is a force which is destined to change the face of the world; I refer, of course, to the movement designated by the broad, general term of Socialism. Many people who are afraid of the name are already, to a great extent, in sympathy with its aims. It has developed an international consciousness, the nucleus of that better understanding of mutual interests which will in time make war impossible. It has not yet realised itself sufficiently to become one vast organisation. Even in this country it is represented by groups, acting more or less in mutual accord, but severally distinct. Thus we have the Fabian Society, the Social Democratic Federation, and the Independent Labour Party. But the striking and significant thing about the movement thus exemplified is that it has given rise to a sense of comradeship between the industrial workers of the world which overleaps ordinary national boundaries; the workman of Chicago feels in closer sympathy with the workman of Berlin and London than he does with the Trust magnate in the next block - I mean the workman who is conscious of the existence of the international movement to which I refer. Here we have, then, the birth 
of a genuine international consciousness which seems destined to grow with considerable rapidity, and to do by direct pressure of public opinion what all the arts of diplomacy have hitherto failed to do in securing the peace of the world. This was strikingly evidenced a little while ago when the Tyneside workers drew upon their own funds for the assistance of the strikers in the North German coal dispute. The International Socialist Congress, which met recently at Stuttgart, marks a long step in the same direction. The impressive thing to be noted about such gatherings is that at the very moment when international jealousy is so pronounced between England and France on the one hand, and Germany on the other, the leaders of the socialist parties in the legislatures of these same countries should meet on common ground with the apparently perfect realisation that they are one and the same party united for the attainment of a common object. Of what other political party or economic organisation in the world could this be said? It is inconceivable that British Liberalism, for instance, should send delegates to meet and confer with American democrats for the furtherance of their common principles. There are no such principles. The ordinary political parties of the several States of Christendom are purely local and limited in their outlook, and never pretend to be anything else. Here, for the first time in the history of the world, is a party, or, rather, a movement, political, eco- 
nomic, and moral, which deliberately takes world politics into its purview, and aims at nothing less than international brotherhood. If ever this movement should become one vast, compact, world-wide organisation, it will revolutionise statecraft as we have hitherto understood it.

But, after all, this is only a small part of what may be looked for from the advent of such a movement. The most hopeful thing about it is that it marks the awakening of the social consciousness in every nation, and comes as a message of hope to the oppressed and unprivileged everywhere. It has taken the movement a long while to do this, and it has made many mistakes in its experimental stages. I do not propose to write a history of Socialism, but it is worth while pointing out that it has now outlived the era of crude and partial experiments, and has come to be reckoned with as the most serious and portentous of all the forces at work in the modern world. The time has gone by when Socialists were laughed at or dreaded as mere faddists and revolutionaries, disturbers of the political equilibrium, but not otherwise important. Perhaps even now they may be thought of in some minds as belonging to the same order as anarchist bomb-throwers, and associated with secret societies and barricades. Statesmen like Herr Bebel in Germany, and M. Jaurès in France, have done much to dispel that kind of illusion. In this country few would be disposed to connect Mr. Bernard Shaw and Mr. Keir 
Hardie with assassinations and incendiarism. It is no longer possible for serious-minded people to misunderstand the quality and temper of the leaders of the Socialist movement, although they might dread the advent of the day when their ideals should prevail so far as to place the government of this or any other country in their hands.

Socialism and the churches. - So far, then, we have taken note of two outstanding features of the life of to-day, the decline of the churches and the rise of Socialism. We have not inquired whether the two are connected, or whether Christianity is likely to survive this process of dissolution and change. But let me say here as emphatically as I can, that what appears to me to be going on in this decline of one set of institutions, and the rise of another, is simply the revival of Christianity in the form best suited to the modern mind. I am aware that few have yet seen this to be the case, but before long every thoughtful mind will be compelled to see it. What is really at stake, it is the object of the following pages to show.

It is a noteworthy fact that so far the Socialistic movement has received but little encouragement from the churches, and, to a considerable extent, has developed in antagonism to them. In this country, to be sure, the Christian Social wing of the High Church Party has identified itself more or less closely with the Labour movement, and many of the clergy have openly professed themselves Social- 
ists. But such clergy are only a small minority of their order, and it could hardly be maintained that they are in any sense necessary to the movement; it could go on quite well without them, and they know it. Taken on the whole, it must be confessed that the Free Churches have done less for the movement than the High Anglicans. No doubt this is partly due to the traditional alliance between Nonconformity and the Liberal party, an alliance which proved very useful to the present Government at the last General Election. The Free Church Council is a Liberal political caucus, and this fact may yet prove its undoing. It is hardly to be supposed that the young Free Churchmen of keen social sympathies who are coming into public notice will care to lend whole-hearted support to an organisation which is at the beck and call of the political party which represents in a preponderating degree the interest of the bourgeois class. On the other hand, there would appear to be an essential antagonism between democracy and sacerdotalism. If the case which I hope to present for Christianity in this book is the true one, it is impossible to resist the conclusion that sacerdotal Socialists are Socialists not because of, but in spite of, their sacerdotalism. On the Continent this is recognised much more fully than here. Here the clergy are much more in touch with the body of the nation than is the case in France, or Italy, for example. In these countries the opposition between Socialism and clericalism is ex- 
treme, and there is not the slightest likelihood of a better understanding. History has taught the leaders of the democracy not to expect much from Roman Catholicism, or, indeed, from Protestantism either. In every country it is the same story: The churches are one thing, the Socialist movement is another; and, despite individual instances of clerical Socialism, official Christianity is not only quite distinct from Socialism, the two are antagonistic.

Socialism and the Kingdom of God. - Is there any necessity why this should be so? I think not, although I have little hope that there will be much change for a good while to come. There is good reason for the antagonism, and the reason is that the churches have been captured to a large extent by the forces which Socialism seeks to destroy. The churches have largely forgotten their own origin, and, so far, there is not much indication that they are likely to recall it. We are thus confronted with a most curious and anomalous situation: The Socialism which is developing so generally in antagonism to conventional Christianity is far nearer to the original Christianity than the Christianity of the churches. The objective of Socialism is that with which Christianity began its history. Socialism is actually a swing back to that gospel of the Kingdom of God which was the only gospel the first Christians had to preach; the traditional theology of the churches is a departure from it. I do not mean, of course, to make the foolish statement that primi- 
tive Christianity was identical with the Socialism of to-day; it was not, but it was far nearer to the Socialism of to-day than to the official Christianity of to-day. Indeed, we may say that its aim and purpose were so nearly akin to those of present-day Socialism, that the latter may, without the least exaggeration, be described as the inheritor of the true Christianity. This is a comprehensive statement but I hope to make it good. 


\section{CHAPTER II}

THE KINGDOM OF GOD

\section{In Jewish History}

The evangel of primitive Christianity. - The ordinary church-goer nowadays takes for granted that Christianity as he knows it is the religion which Jesus brought to the world, and represents what the original followers of Jesus believed and taught. So far is this from being the case, and so well do biblical and historical scholars know it, that it is astonishing to witness the immobility of the churches in presence of the facts.

Christianity began as the glad tidings of the Kingdom of God. Its Founder did not invent this name, and neither He nor His followers knew that they were promulgating a new religion which would last for many centuries after His death, and would become interwoven with a new civilisation. It can hardly be necessary to say that it never occurred to them to call it Christianity; that was a much later development. All that Jesus did, as we are told in the gospel records, was to begin preaching among His countrymen of Israelitish race the glad tidings of the Kingdom of God. He did not find it necessary to explain 
what He meant by the Kingdom of God, for every one knew already - that is, every one who had been brought up as he had been brought up under the influence of Jewish faith and tradition. What, then, was this Kingdom of God, and where did the idea come from? In order to answer that question we must go to the records of the race to which Jesus belonged and the people to whom He first delivered His message. $\mathrm{He}$ was a native of Galilee, but $\mathrm{He}$ traced His descent from the ancient Israelitish stock. Our best source of information about the habits and ideas of this race is unquestionably the Old Testament scriptures. But I would ask my readers to remember that in any use I may make either of the Old Testament or the New my purpose is simply to illustrate the growth of ideas. With this purpose in mind, we must regard the Bible as a collection of purely human documents possessing a fascinating interest from the historical point of view. We shall treat it as we should treat Froissart or the Saxon Chronicle. Fortunately, we are nowadays in a position to understand better than was formerly the case most of the historical allusions made in familiar scripture passages.

Early Israel a theocracy. - The Israelitish people had always looked upon themselves as being in a special sense the favourites of God. Far back, at the beginnings of their national history, they no doubt thought of Jehovah (Yahweh) as their God in contradistinction to the gods of other nations. 
Jehovah was their divine sovereign, and they were his subjects. Tradition had it, indeed, that the later choice of a human sovereign to lead them in battle like the military sovereigns of other nations, was a perilous experiment, which, for a time, exposed them to the divine disfavour; the earlier, or more ideal state of things, was when they were directly governed by the divine will operating through specially chosen individuals. During this primitive period, then, the political constitution of the Israelitish people was a theocracy or Kingdom of Jehovah. This was the view which later tradition took of the matter.

The two tendencies: universalism and nationalism. - As time went on, Israel began, under the pressure of influences which we need not now pause to examine, but principally through the work of the great preachers called prophets, to think of Jehovah as the one and only God, the God of all the nations upon earth. They still held themselves to be in a special way His chosen people, and, although they were governed by ordinary human sovereigns like other nations, they thought of their little kingdom as the Kingdom of God. Perhaps it would be truer to say that later generations looking back to this period of their national history thought of it in this way. But from the time when Israel really entered into the great family of nations two distinct and even conflicting tendencies made their appearance in relation to the great question we are discussing. The 
nobler and more spiritual of the two was the tendency to think of Israel as specially called to witness for the one and only God amongst the nations of the earth, and to work for the day when all mankind would be consciously and directly under the divine government. The other tendency was to look upon Israel as the only people who were of any account in the world, the people of God. This second tendency was as mischievous in its after results as the first was great and noble. Probably it would be true to say that the great mass of the nation never did attain to the wider and more spiritual ideal indicated in the former of these tendencies, but unquestionably some of the great prophets did. There is a striking passage, for instance, in Isaiah xix., which illustrates this:

"In that day shall there be a highway out of Egypt to Assyria, and the Assyrian shall come into Egypt, and the Egyptian into Assyria; and the Egyptians shall worship with the Assyrians. In that day shall Israel be the third with Egypt and with Assyria, a blessing in the midst of the earth; for the Lord of Hosts hath blessed them, saying, Blessed be Egypt My people, and Assyria the work of My hands, and Israel Mine inheritance."

A passage like this is all the more remarkable when we remember that it was written long before the great captivity, at a time when Assyria and Egypt were the great powers of the ancient world and Israel only a little buffer state between them. It indicates an exalted belief in the coming of a universal divine 
order which should mean a federation of all nations in the ways of righteousness, prosperity, and peace. In another part of the same book we have the social effects of this consummation described thus in metaphorical language:

"And the wolf shall dwell with the lamb, and the leopard shall lie down with the kid; and the calf and the young lion and the fattling together; and a little child shall lead them. And the cow and the bear shall feed; their young ones shall lie down together; and the lion shall eat straw like the ox. And the sucking child shall play on the hole of the asp, and the weaned child shall put his hand on the basilisk's den. They shall not hurt nor destroy in all my holy mountain: for the earth shall be full of the knowledge of the Lord, as the waters cover the sea."

This was really a beautiful dream, and something more than a dream; it is still the world's hope. The wonderful thing is that an Israelitish prophet should have seen this ideal so clearly nearly three millenniums ago, and that all through the later history of the people to whom he belonged this ideal should have been continuously presented by men of vision and faith.

Influence of the captivity on the national consciousness. - It was not, however, till after the great captivity in Babylon that the idea of the Kingdom of God took definite shape in the mind of the Jewish people as a whole; and it is improbable that it ever became to any very large number of them the lofty and noble conception illustrated in the lan- 
guage just quoted. For a considerable period before this captivity Israel had been divided into two kingdoms. The northern kingdom was destroyed by the Assyrians; it was the southern, or kingdom of Judah as it was called, which carried on the Israelitish tradition, and whose scattered representatives continue to do so to this day. Nebuchadnezzar, king of Babylon, carried away the flower of the Jewish nation to his rich and mighty capital eight hundred miles from their highland home. There they remained for more than two generations. Some of the most beautiful and pathetic passages in their religious literature were composed during this protracted exile, and show us how the imprisoned people thought about the national destiny. About the middle of the sixth century B.c. Babylon fell before Cyrus the Persian, and the captive Jews were permitted to return home to take up again the thread of their interrupted national existence. When they got back to their own land they found, as might have been expected, that those who had been left behind during the period of Babylonian overlordship had not kept as closely to the faith and customs of their fathers as the exiles themselves had done. For one thing the exiles had been the better part of the nation; and, for another, they would be sure to pride themselves in remaining as distinct as possible from their conquerors and practising their own religious forms. It does not follow from this that all the exiles were equally particular, or even that they 
all took the trouble to return home when the emancipation took place; only the more earnest and patriotic among them would do that, and it must have been a shock to these to find that the survivors in the home land had allowed things to drift and the forms of the national worship to become disintegrated. The result was the formation of a nation within the nation, so to speak, an Israel jealously careful of the political and religious traditions of the past in contradistinction to the Israel which had ceased to attribute much importance to these things. This stricter Israel tended to become more and more exclusive as time went on. Its leaders magnified and elaborated every precept. of the so-called Law of Moses; the whole life of the pious Jew was regulated by the Law down to the minutest detail. The national consciousness thus became even more intense than it had been before the great captivity, and remained so in spite of all the vicissitudes through which it had yet to pass. But from this time forward the Jews were never without a foreign master. The Persian rule was succeeded by that of the Greeks, and at the commencement of the Christian era Palestine became included in the vast Roman Empire which was now co-terminous with the civilised world.

Idealising the past and dreaming of the future. Throughout all these changes Jewish patriotic and religious sentiment continued to dwell upon the theocratic kingdom of the remote past, and to ; 
imagine a yet more glorious future. It is not surprising that, under the circumstances, the narrower national party which had existed ever since the return from the captivity should have dwelt much upon the supposed restoration of Israel's former glory and should have pictured it as being accompanied by the complete and final overthrow of all her enemies. They searched every line of the sacred writings for prophecies bearing upon this much to be desired consummation, and where prophecy was silent popular imagination supplied the lack. Most of the postexilic prophetical writings contain some allusion to this hope. Thus, for example, writes a later Isaiah:-

"Thy gates also shall be open continually; they shall not be shut day nor night; that men may bring unto thee the wealth of the nations, and their kings led with them. For that nation and kingdom that will not serve thee will perish; yea, those nations shall be utterly wasted. The glory of Lebanon shall come unto thee, the fir-tree, the pine, and the box-tree together; to beautify the place of My sanctuary, and I will make the place of $\mathrm{My}$ feet glorious. And the sons of them that afflicted thee shall come bending unto thee; and all they that despised thee shall bend themselves down at the soles of thy feet; and they shall call thee The city of the Lord, The Zion of the Holy One of Israel."

It is clear from a writing of this kind that to a patriotic Jew from the sixth century B.C., right on till the fall of Jerusalem before the Roman power in A.D. 70, the idea of the restoration of the King- 
dom of God was synonymous with that of Jewish dominion over all other nations. It is quite wonderful how this dream persisted, despite all probabilities. How these people should ever have thought it possible that the tiny Jewish nationality could attain to such a position of prominence and power must remain a mystery to us, but they did think it. Looking back to the great days of David and Solomon, they idealised the conditions prevailing at that time as contrasted with the sorrows and sufferings of later generations. To them David was the man after God's own heart, and his kingdom was thought of as having been in reality a Kingdom of God, a reign of splendour and greatness, of joy and plenty under the favour of Heaven. When the poor, burdened, tribute-paying Jew of later days looked back to David's day, it was quite natural that he should think of it as having been an ideal time in the national history, although it was far different in reality from what it became in later legend. What the people wanted was that David's day should come again with added greatness and splendour, and that some prince of David's line should reign in Jerusalem and exercise sovereign sway over all the rest of the world. They easily persuaded themselves that such a day would certainly come sooner or later, and that God, by some striking demonstration of His power, would not only restore the Kingdom as it had been in David's day, but would miraculously add to its greatness and splendour by overthrowing 
all other kingdoms before it. This popular association of David's name with the growth of expectation concerning the Kingdom is a tribute to the impressiveness of the personality of that great prince. Most nationalities have some such hero of tradition, half historical, half legendary, around whose name gathers the cumulative expression of race-loyalty. David was to Israel something of what Alfred is to England, and Frederick Barbarossa used to be to Germany. According to later Jewish tradition the succession to the throne of Israel was divinely guaranteed to the house of David; how fondly this tradition was cherished in the long dark days of the national humiliation is evident from the language of Scripture, especially the New Testament.

"I will set up one shepherd over them, and he shall feed them, even My servant David; he shall feed them, and he shall be their shepherd. And I the Lord will be their God, and My servant David prince among them; I the Lord have spoken it. And I will make with them a covenant of peace, and will cause evil beasts to cease out of the land: and they shall dwell securely in the wilderness, and sleep in the woods (Ezek. xxxiv. 23-25)." "I will give you the holy and sure blessings of .David (Acts xiii. 34)."

All such writings as these - and there are many of them-prove conclusively that the name of David lived on in the Jewish mind as the symbol of a glorious past and the hope of a still more glorious future. It is pathetic as well as interesting to note the way in which, centuries after Judæa had ceased 
to be a kingdom, her people clung to the expectation that the kingdom would one day be reinstituted, and that its earthly head would be a prince born of David's line.

The Messiah. - As a consequence of this persistent expectation, carefully fostered and encouraged by the national party, there grew up a considerable body of tradition concerning the personality of this supposed successor of David, whose special work it should be to restore the Jewish kingdom. He was usually referred to as the Messiah, that is, the SentOne. As this is a term which has come to bear a certain theological significance in connection with Christianity, it may be as well to look into its origin before passing on.

It should be noted that the word Messiah is used in the Old Testament of others than the prince of popular tradition; it was originally employed to designate any messenger or representative of God. Thus (Lev. iv. 3) it is used of the High Priest. In Ps. cv. ${ }_{5}$ it refers to the prophets. In Isa. xlv. I it is actually used of a foreign potentate, Cyrus, the deliverer of Israel from Babylon. It was comparatively late before it became restricted so as to denote only the prince of the house of David, who was to appear as God's representative or instrument to drive out the foreigner and assume the government. Not all the Old Testament passages which are supposed to refer to this consummation do so in reality. Thus, for example, the ancient saying - 
"For unto us a Child is born, unto us a Son is given: and the government shall be upon His shoulder: and His Name shall be called, Wonderful, Counsellor, The Mighty God, The Everlasting Father, The Prince of Peace. Of the increase of His government and peace there shall be no end, upon the throne of David, and upon his kingdom, to order it, and to establish it with judgment and with justice from henceforth even for ever (Isa. ix. 6, 7)."

This familiar passage, so often used in Christian worship, has no reference whatever to what has come to be called the Messianic hope; it deals with a situation which was purely local and contingent; at the time it was written Israel was still a kingdom, and the house of David had not ceased to reign. But things were altogether different when it became a question of looking back to David's day across intervening centuries of misery and subjection; consequently the Messianic hope to patriotic Jews meant the emergence of a specially gifted being who should go farther and do more than David had ever done in the glorification of the chosen people and the removal of all their disabilities.

Where this gifted individual was to come from was never very clear, and the views held about it among the Jews at the commencement of the Christian era were to a great extent mutually contradictory. As time went on, the tendency in thought was to ascribe more and more supernatural power to the Messiah, although it does not appear that he was at first regarded as other than a divinely chosen 
human being. There were some who held that he was a prince who had been taken up into heaven and kept there until the time should be fulfilled for his re-appearance on earth and the performance of his God-appointed work; others identified him with a pre-existing Man from heaven, who should later on become incarnate on earth, "of the seed of David, according to the flesh." This idea of the Man from heaven will require a further examination, for it exercised a considerable influence on the development of Christian thought through the Apostle Paul. For the moment what we need to recognise is that all the various theories about the personality of the Messiah agreed in one particular, namely, that his kingdom would supersede all other kingdoms, and would be a veritable kingdom of God on earth a fulfilment of the ancient prophetic dream of a Commonwealth of righteousness, peace, and plenty. There were very few among the patriotic Jews of Jesus' day, who would have conceded that the benefits of this kingdom had anything to do with Gentile races; they were to be reserved exclusively for the descendants of Abraham. For a century or two before Jesus was born this idea held the field, at any rate among the strictly national party. Then, as now, there must have been a large body of indifferentists who did not trouble their heads much about the Kingdom; and there certainly was a strong party, including the most highly placed among the hierarchy, who were desirous of seeing Jewish reli- 
gion more closely assimilated to cosmopolitan Greek culture. These were fiercely opposed by the national party, to whom the Messianic hope was allimportant. Thus at the moment when Jesus was born, there was a distinct cleavage between GræcoJewish culture, as represented by Alexandria, and Palestinian Judaism, as represented by the Pharisees. The latter tended to become narrower and narrower, and to think of the expected Messianic Kingdom or Kingdom of God as being exclusively for the benefit of the faithful among the chosen people, that is, for those who had adhered most closely to the prescriptions of Jewish law and tradition. The Kingdom of God, in their sense of the word, was simply a revival of the ancient Jewish monarchy, as they pictured it, coupled with the additional advantage of affording to the oppressed Jews the satisfaction of triumphing to the fullest degree over every foreigner, but especially those who had ever done them any mischief. I do not say that this was precisely what every one thought about the Kingdom, but it represents the dominant expectation; in its main features it was, therefore, purely political and materialistic.

Apocalyptic ideas of later Judaism. - How this programme was to be carried out could not possibly be stated with anything like fulness, for there were no facts to go upon: but speculation indulged in many curious fancies. At one time there must have been a large apocalyptic literature, setting forth in 
vague, symbolic language the various views which were entertained concerning the coming of the Kingdom. The most important work of this kind which has come down to us is the Book of Daniel. This book was probably written a little before the middle of the second century before Christ, and is therefore instructive as showing the kind of expectation which was prevalent in reference to the Messianic Kingdom. The writer pictures the rise of one secular power and then another, culminating in the "kingdom of the saints." Of course the saints were the Jews, and the teaching of the book plainly is that the various world-powers which had held dominion up to that time, and to whom the Jews had usually been subject, would be utterly overthrown, and the saints would take their place.

"And the kingdom and the dominion, and the greatness of the kingdoms under the whole heaven, shall be given to the people of the saints of the Most High: His kingdom is an everlasting kingdom, and all dominions shall serve and obey Him (Dan. vii. 27)."

Another peculiar passage in this book is evidently a reference to the popular idea of the Messiah; at any rate, this is the sense in which it is quoted later in the New Testament:

"I saw in the night visions, and, behold, there came with the clouds of heaven one like unto a Son of Man, and He came even to the Ancient of Days, and they brought Him near before Him. And there was given Him dominion, and glory, and a kingdom, that all the peoples, nations, and languages 
should serve Him: His dominion is an everlasting dominion, which shall not pass away, and His kingdom that which shall not be destroyed (Dan. vii. I3-14)."

It is possible that the Son of Man here spoken of is not the Messiah in particular but the Jewish nation as a whole; but, whether or no, the reference to the Kingdom is obvious.

Influence of non-Jewish ideas on Messianic hope. - A good deal of the speculation concerning the Messiah and the Kingdom of God, which was so widespread at the opening of the Christian era, owes something to non-Jewish sources. It is probable for one thing that, in spite of the hostility of the strictly national party to the influence of Greek culture, Greek ideas even found their way into popular Jewish expectation concerning the pedigree of the Messiah. The reaction of Palestinian Judaism against the all-pervading influence of Greek ideas did not begin soon enough to prevent this; it is even probable that the party afterwards represented by the Pharisees, the party which was most hostile to any suggestion of admitting non-Jewish religious ideas, was dominated by Greek conceptions to a far greater extent than it was aware of. Thus the original patriotic expectation concerning the coming of -a gifted human leader to free the nation from its bondage, gradually became mixed up with purely philosophical speculations about the Logos, through whom, according to a certain type of Greek thought, God was supposed to have created the world. The 
fusion between this idea and Jewish religion was made in Alexandria, not in Palestine, and its principal author was Philo - a cultivated Alexandrian Jew, who was born a few years before Jesus. But it is not to be supposed that Palestine could have altogether escaped the influence of ideas which were in the air for a long time before Philo wove them into his system of thought, and were the necessary fruit of the daily intercourse of Jew and Greek. A glance at Philo's teaching ought, therefore, to show us something of what Jews in general were thinking about the status of the Messiah at the time when Christianity came into being.

The Logos idea. - Philo taught that God was so infinitely exalted above the world that it was impossible to think of $\mathrm{Him}$ as coming into contact with it, and impossible to predicate anything with certainty concerning Him. We can know nothing about Him, and it is futile to ascribe any excellence to Him, for our finite notions of excellence can have no meaning as applied to God. He is the absolute, the inconceivable; we cannot attempt to describe Him without falling into absurdity. To speak of Him in terms of human conceptions of the true, the beautiful, and the good, leads nowhere, and achieves nothing. Philo's starting point is thus very similar to that of Herbert Spencer. From this position of nescience Philo goes on to speak of God as acting upon the sensible world through intermediate beings. At the head of these he 
places the Logos. He thinks of the Logos as the being or principle through whom the world is created and sustained. $\mathrm{He}$ is a kind of second God, but not identical with the absolute God; he is the firstborn of every creature. All through the history of mankind the Logos has been revealing God; $\mathrm{He}$ is the source of everything that is God-like in human nature, the heavenly Man. Now, although Philo elaborated this idea, he did not invent it, he borrowed it from the Stoics, and the general conception of the relations of God and the world which it implied was borrowed from Plato. From this kind of philosophising it was but a step to the identification of the Messiah of Jewish national hopes with the Logos of Greek thought, and we now know that this identification was being attempted in Jewish popular religion before there was any Christianity at all. People were talking about the Man from heaven, meaning the Messiah, and at the same time thinking of Him as invested with most of the attributes of the Greek Logos as interpreted by Philo and his followers. Philo only put into shape what was already being vaguely thought and said by many of his contemporaries of his own race and time.

Persian dualism. - But it was not only Greek influence which was at work in Jewish popular religion at this time; there were Oriental influences at work too, especially Persian. Considering that the Jewish exiles in Babylon some centuries before 
had owed their deliverance to Persia this is not surprising. But Persian religion rested upon an even more absolute dualism than the Greek philosophy, which formed the substratum of Philo's system of thought. According to Persian notions the universe was sharply divided between the two opposing powers of light and darkness, good and evil, Ormudy and Ahriman, or God and Satan. The ordinary present-day idea of Satan with which people frighten children in Christian lands is derived directly from this old-time influence of Persian dualism on Jewish religion. In still earlier Jewish religion Satan was not considered to be an evil spirit; he was one of the angelic servants of God, the accuser of men, but not the enemy of good. But as soon as Persian dualism laid hold of the Jewish imagination the character of Satan underwent a metamorphosis; henceforth he was thought of as the captain of the host of evil in opposition to the holy will of God. All nature and all human history were now looked upon as the scene of this conflict, a conflict to which of course there could only be one issue, namely, the catastrophic triumph of good. For the present, so it was thought, Satan had the best of it; all the earthly kingdoms were in his mighty grip, and even God's people were in bondage to him and were suffering accordingly. God was being kept out of His proper dominion over the souls and bodies of men because of this usurpation; Satan was "the prince of this world." 
In the end, however, God would resume His sovereignty with a strong hand, and the kingdom of Satan would be overthrown. The ideas absorbed by Judaism from this source are thus not unimportant for the consideration of our subject; it will be seen at once that they have a considerable bearing upon popular ideas concerning the establishment of the Kingdom of God. But the result of the operation of such ideas was the development of a bewildering number of fantastic theories concerning the person of the Messiah and the way in which he was to appear. According to some $\mathrm{He}$ was, as we have seen, the Logos through whom the cosmos itself was created and sustained. Others regarded Him as a divine Man existing before the creation, and due to descend into the world in the fulness of time, and put an end to Satan's rule. Others, again, still continued to think of Him as an earthly conqueror of the seed of David whom God would gird for the task of fighting against and overthrowing all the world-powers which were supposed to represent the dominion of Satan. It should not be overlooked, however, that the inheritors of the promise as thus construed were supposed to be the children of Abraham; outsiders could only benefit through them, if at all. It thus became easy to think of the "world" as synonymous with the kingdom of Satan, and of all the kingdoms of the world as being more or less his instruments and under his obedience. With such a general conception as this the thorough- 
going Jewish patriot trained under Pharisaic methods could find but little room in his heart for charity towards the Gentiles. Gentiles did not count; they were outside the covenant; they were classed in a lump as the servants of Satan. A good Pharisee could have said of himself and his party, just as some of the Christians did later on, "We know that we are of God, and the whole world lieth in the evil one" (I John v. I9).

Pessimism of later Jewish thought. - This view of the world as being essentially opposed to God, and a synonym for all the evil tendencies in human nature, led naturally to a view of human history which was as false as it was depressing, namely, that mankind had begun well and ended miserably. In much of the rabbinical lore of the period immediately preceding the birth of Christianity the assumption is made that the present is but the ruins of the past, and that all the sorrow and suffering of humanity, as well as all its wickedness, were due to the intrusion of evil in an otherwise ideal creation. The legend of the Garden of Eden became hardened into dogma, and ideas were read into it which it did not really contain. This Genesis story of the Fall, as it has since come to be called, had never exercised any great influence on Jewish religious thought hitherto, as is plainly evident from an examination of the Old Testament, where it is hardly even mentioned, much less taken seriously. It only became a dogma when the star of the national fortunes had 
declined, and men were casting about to find some way of accounting for God's apparent abandonment of His people to the will of their conquerors. It was Jewish pessimism that produced the theory of a lost and ruined world, and that pessimism is surely explainable when we remember what the nation had suffered ever since the great captivity.

Popular Græco-Jewish Cosmogony. - Alongside of these ideas of the past and future of the race went a view of the structure of the universe and the destiny of the individual soul which have long ceased to have any meaning for the modern western world. I refer to the belief that the universe was in three planes - the earth in the middle, heaven just above the sky, Sheol or Hades down below the surface of the earth. This belief was practically universal in the civilisation of that day, for neither Galileo nor Columbus had yet arisen. There were some thinkers, indeed, who had a truer view of the matter, but it had not laid hold even of the world of culture, and it was not to be expected that it should. The ordinarily accepted view was destined to hold its own until comparatively modern times, and to be inherited from Græco-Jewish thought by the Christian church; the pity is that the church of the present day has not seen fit to alter her theology with her cosmogony. It should be noted that in early Jewish religion there was practically no thought of personal immortality; the only immortality present to the minds of prophets and psalmists was the immor- 
tality of the nation, an immortality wholly of this world. In earlier Jewish belief, therefore, Sheol, or the under-world, was practically synonymous with the grave. "In death there is no remembrance of thee; in Sheol who shall give thanks?" (Psalm vi. 5). When, later on, the idea of personal immortality began to dawn in the Jewish mind, Sheol came to be thought of much in the same way as the Greek Hades, that is, as a gloomy and mysterious region in which the souls of the departed remained in a state from which all the light and joy of earth-life were excluded. In the last century B.c. thought was in a comparatively fluid state concerning this underworld and its denizens, so much so, that it is impossible to regard any one theory as being consistently or generally held. It was widely believed, however, that there was a difference in the lot of the good and the bad respectively; the former, although in the under-world, were received into the state of peace piously termed "Abraham's bosom," while the latter were tormented. Others spoke of the state of the departed as a sleep, and one very considerable party maintained that it was a sleep from which there would be no waking. This last-named view was abhorrent to the typical Jew, for it was antagonistic to his theory of the coming of the Kingdom. What he looked for when the Messiah came was a universal judgment for which the dead would have to come up from the under-world; this judgment would result in the purging of the earth plane from all the 
evil that afflicted the chosen people and the shutting of all the servants of Satan down in Hades.

In this brief review of the main ideas concerning the Kingdom of God which existed in the Jewish mind at the moment when Christianity began many developments have necessarily had to be omitted. Even as it is, the statement may seem to some readers to be unduly theological and to devote too much attention to beliefs which have long since become obsolete, and can have no sort of value for the modern mind. In my judgment, however, the survey has been necessary in order to show something of the intellectual environment in which the religion of Jesus took its rise, and, therefore, what the starting-point of apostolic preaching had to be. If we do not understand the conventional ideas of the GræcoJewish world of Jesus' day we shall not understand primitive Christianity. It will already have become evident to those of my readers who have not had much previous acquaintance with the subject that the ideas described in this chapter are taken for granted on nearly every page of the New Testament.

Summary. - To summarise the situation, then, let us recognise that the germ of the early Christian idea of the Kingdom of God is to be found in Jewish belief in the theocratic constitution of ancient Israel. The great preachers, whose words are recorded in the Old Testament, had held up to the national consciousness the ideal of a universal brotherhood of nations under the sovereignty of God, and had declared it 
to be Israel's vocation to witness this to the world. But, for the most part, and never more so than at the time when Jesus was born, the Jews had come to believe that they were the only people who mattered much to God. They were confident that a good time was coming, and this they thought of as the restoration of their ancient theocratic State with greater power and splendour than it had ever possessed before. They believed that this Kingdom of God, as they called it, would be established suddenly and by force; that God would raise up a descendant of David to do it; that it would include vengeance upon Israel's enemies; and that it would culminate in a period of general prosperity and peace. No doubt there were many pious and humble souls who thought of the good time coming as the victory of goodness rather than the triumph of Jewish national pride, but these could never have been more than a few at any time; the general view was more political and materialistic. With the lapse of time the expected national deliverer became thought of as a quasi-supernatural being who would do all kinds of wonderful things, but still most people thought of him as being born into the world in an ordinary way and growing up like an ordinary man. When the supreme moment came, and this Messiah entered into conflict with world powers, His victory would be signalised by a general judgment to which the dead would be summoned as well as the living; this judgment would be followed by a thorough purging of 
the earth from everything evil and the inauguration of the uninterrupted reign of the saints, that is, of the faithful among the descendants of Abraham.

This was the general Jewish expectation concerning the Kingdom of God, the expectation in which the Founder of Christianity Himself was trained, and which He took for granted in all His hearers. We have now to observe the ways in which this expectation, and the ideas commonly associated with it, coloured Christian thinking and preaching in the apostolic age. 


\section{CHAPTER III}

\section{THE KINGDOM OF GOD}

\section{In Primitive Christianity}

The Christian sources. - Christianity, as we have seen, began as the proclamation of the near advent of the Kingdom of God. The special teaching associated with this proclamation is stated to have been given by Jesus of Nazareth, who is now regarded as the central figure of human history. If estimated by his achievements this position is well deserved; no master of men is comparable to Jesus in influence over the destinies of mankind. There are those who would say that this influence is due to an ideal formed by the Christian imagination rather than to an actual historical personage; such critics would maintain that we know so little about Jesus that we are not justified in asserting anything positively about His character and teaching. Still, I think the consensus of scholarly opinion to-day would be not only that Jesus really lived, but that His personality must have been one of unique greatness and power. But, apart from the doubtful testimony of ecclesiastical tradition, our only sources of information about Jesus are the writings collected in the New Testament, and 
these are all of later date - some of them of much later date - than the period of His ministry. So far as we know He wrote nothing Himself; so we are entirely dependent upon second-hand reports of His words. This renders the task of forming a judgment upon those words a difficult one, especially as that part of the New Testament which professes to record them is not the earliest. But for our present purpose this does not greatly matter, for we have to recognise that, great as the personality of Jesus may have been, Christianity was largely the product of the intellectual and religious environment in which it arose; it could not have been a complete breach with the past, nor is it reasonable to suppose that Jesus Himself stood altogether unrelated to the Judaism which supplied His mental and moral training. For the purpose of our present inquiry, therefore, we are less concerned with what Jesus actually said and did than with what the primitive Christian society thought about Him and His value for mankind, which is exactly what the New Testament, read in the light of contemporary history, enables us to discover. This is quite a reasonable standpoint to adopt, and one which is less open to objection than any other. The important thing to ascertain is what were the main ideas taken for granted by these first Christians, and what was the message they supposed they had to deliver to the world. The best way of getting at this will be to follow the traditional order rather than 
begin with the doctrinal epistles, although probably these were the first to become literature. I omit the fourth gospel for the present, for it is not a biography at all, but a religious treatise, like the epistles, its author having adopted the literary device of employing the narrative form to set forth his ideas.

John the Baptist. - We learn, then, from the synoptical gospels that the work of Jesus was prepared for by the emergence of a remarkable preacher who has become known to Christian tradition as John the Baptist. I do not mean that this preacher was a divinely appointed and long-expected forerunner of the Messiah in the sense usually understood in Christian circles to-day. I mean that a man of prophetic temper and courage, a latter-day Elijah, stood forth as the exponent of a truer and nobler view of the meaning of the Kingdom of God than that which had become popular. Any one who reads the New Testament without being possessed by the ordinary presuppositions of dogmatic Christian theology will see at once that this man was addressing himself to the mental environment of his time, and that he never got beyond it. His preaching was a protest against the materialism of prevailing ideas concerning the nature of the Kingdom, but, like so many of his contemporaries of Jewish race, he fully believed the Kingdom to be near at hand. He believed, too, in the contemporary notion of the Messiah and His work. It is evident, 
from such fragments of his discourses as have come down to us, that he thought of the coming of the Messiah as a kind of universal judgment, in which all evil elements should be purged out of human society, followed by an entire reorganisation of human affairs. Neither is there any reason to doubt that he was a loyal nationalist in his conviction that the Jewish people would occupy the supreme position in the new order, and that their Messiah would be the universal monarch. It was because he believed all these things in common with the people he addressed that he obtained immediately such an extensive hearing; but, probably, it was his eloquence and moral austerity which gained him the influence he undoubtedly wielded over the popular mind for a considerable period. He was filled with indignation at the trickeries and insincerities of the religious ruling class, who talked much about the Kingdom without realising that the one indispensable requisite in the new order when it came, would be personal righteousness of a real, and not merely of a ceremonial, kind. For men of covetous and grasping spirit to talk about an ideal social order was absurd, and he told them so. The belief that real righteousness of life did not matter so long as a man was descended from Abraham, he regarded as a most mischievous perversion of the truth about the Kingdom. It seems that the main thing which drove this successor of the prophets into the open and made him a preacher was his first-hand acquaint- 
ance with the social inequalities and unredressed wrongs of the people among whom he dwelt. We now know, as everybody knew then but submitted to it, that the aristocratic priestly order made large profits out of the disabilities of the people. It is one of the ironies of history that the ecclesiastical order should so often have done the same since in the name of the Founder of Christianity. The men who devoured widows' houses and for a pretence made long prayers were an abomination to John the Baptist; and yet these men were talking about the Kingdom of God in the same way as every one else. It is this which explains the voluntary poverty of the preacher as well as much of his fiery language. His message was social and ethical, inspired by a firm belief in the righteousness of God. When members of the orthodox religious orders came to listen to him, he did not mince matters. Let us look at what he said, but in so doing let us keep our minds free of Christian theology in any shape or form. If it were not for the fact that we are so accustomed to hearing these words read in churches, with all the atmosphere of dogma about them, we should see at once that this man was dominated by the same motive and passion as the social reformers of to-day, and by very little else. Addressing himself to representatives of the orthodox religious classes, he exclaimed -

Ye offspring of vipers, who warned you to flee from the wrath to come? Bring forth therefore fruit worthy of repent- 
ance: and think not to say within yourselves, We have Abraham to our father: for I say unto you, that God is able of these stones to raise up children unto Abraham. And even now is the axe laid unto the root of the trees; every tree therefore that bringeth not forth good fruit is hewn down, and cast into the fire. I indeed baptise you with water unto repentance: but $\mathrm{He}$ that cometh after me is mightier than $\mathrm{I}$, whose shoes I am not worthy to bear: He shall baptise you with the Holy Ghost and with fire: whose fan is in His hand, and $\mathrm{He}$ will throughly cleanse His threshing-floor; and $\mathrm{He}$ will gather His wheat into the garner, but the chaff $\mathrm{He}$ will burn up with unquenchable fire.

We might paraphrase the archaic English of this passage as follows:-

You venomous deceivers! How have you found out that a social revolution is at hand? I suppose you want to make sure of being on the safe side, but you will have to produce better evidence of sincerity in your desire for amendment than you have done up to the present. Do not imagine that descent from Abraham will avail you anything. The real descendants of Abraham are those who, like him, seek to do the will of God in dealing justly with their fellow-men. You are right to be apprehensive, for the reign of hypocrisy and oppression is well-nigh over; the rotten trees will soon be hewn down and consumed. My baptism is only a preliminary, a mere sign of the desire to lead a better life; but the long-expected deliverer will be here soon, and He will baptise the world with the Spirit of God and the fire of retribution. Only the grain will be garnered; the chaff will be burned up in the flame of His judgment. All shams and tyrannies will have to go, and the world will make a fresh start.

Another version of the preaching of the great 
ascetic represents him as giving practical directions to those who sought his counsel -

And the multitude asked Him, saying, What then must we do? And He answered and said unto them, He that hath two coats, let him impart to him that hath none; and he that hath food, let him do likewise. And there came also taxgatherers to be baptised, and they said unto Him, Master, what must we do? And He said unto them, Extort no more than that which is appointed you. And the soldiers also asked Him, saying, And we, what must we do? And He said unto them, Do violence to no man, neither exact anything wrongfully; and be content with your wages.

Whether these records of the utterances of the remarkable man who heralded the movement since known as Christianity be accurate or no does not matter in the least. Their importance consists in the fact that they reveal the mood of the time; they show what people were thinking about. The true distinction of this rugged preacher is that he recalled the minds of his contemporaries to the moral seriousness of the drastic change they so ardently desired to see. No doubt this preaching helped to intensify the popular belief that the long-expected Kingdom would come very speedily by some kind of a catastrophic act of God. We are told that John's hearers earnestly discussed the question as to whether he himself were the national deliverer, a supposition which the preacher set at rest by plainly affirming that his only work was to declare the near advent 
of the Messiah, and to prepare his countrymen for what would then ensue. It is unmistakable that the all-dominating idea in his evangel was that of social regeneration. He quite believed that this would be brought about by force, and his warning to oppressors had therefore a good deal of point. There is no suggestion of other-worldism about the matter from first to last. His message is pure social ethics rendered necessary by the manners of the time and the dual oppression of foreign rule and materialistic ecclesiasticism, as we should call it now. John the Baptist was exactly the kind of man who would have led the attack on the Bastille, or who would nowadays be found addressing a Labour demonstration in Hyde Park. The general expectation as to supernatural interference and a dramatic wind-up to the prevailing condition of things has had its parallels on an even larger scale more than once since that day. At the approach of the year rooo A.D., for example, all Europe seems to have become possessed by the idea that the end of the world was at hand. The Church obtained a considerable accession of wealth and power through the pious benefactions of various princes and nobles, who thought it best to be on the safe side when the crash came. A similar state of pious panic arose in London some generations ago when, owing to an eclipse and the preaching of a fanatic, the greater part of the population of the metropolis encamped in the open air on Hampstead Heath and other places and 
betook itself to prayer under the firm conviction that the Day of Judgment had come. Such vagaries on the part of large masses of human beings are not at all uncommon. We need not, therefore, be surprised at the widely diffused expectation concerning the coming of the Kingdom which gained John the Baptist his hearing, and accounted afterwards for most of the temporary popularity of Jesus. This expectation had been fostered, as we have seen, for generations, and had gradually become more and more definite in outline. It originated in a bitter experience of national humiliation, want, and misery, coupled with a firm belief in the national vocation and the special favour of God.

Emergence of Jesus. - Before long, as was to be expected, John's boldness in rebuking the vices of the time led to his imprisonment and execution. It was then, according to the gospel accounts, that a new and greater prophet came forward - Jesus of Nazareth. If it were necessary to keep our minds clear of doctrinal prepossessions when considering the work of John the Baptist, it is even more so in the case of Jesus. Centuries of religious dogma have made it almost impossible for the ordinary man of to-day to see the work of Jesus in its true historic setting. We need not here discuss the growth of Christian doctrine concerning His status in the Godhead, or even the manner of His birth as set forth in the first and third gospels. What we have to do with is the mental and social 
environment in which $\mathrm{He}$ wrought. He evidently succeeded to the work John had begun, for we are told that, as soon as the Baptist was cast into prison Jesus began to preach, like him, the Kingdom of God. It is impossible to say now with anything approaching to absolute certainly what proportion of the discourses of Jesus, as recorded in the New Testament, is actually in His own words, and how much is due to the mental bias of His hearers. Whether Jesus shared the contemporary belief as to the cataclysmic nature of the coming of the Kingdom is a matter of dispute; perhaps $\mathrm{He}$ did. At any rate, it is evident that $\mathrm{He}$ saw no necessity for telling people plainly that their belief in the nearness of the coming of the Kingdom was a mistake; so there is a good deal to be said for the view that $\mathrm{He}$ Himself shared that belief. But He went even beyond the Baptist in His insistence upon the fact that material plenty was not in itself sufficient for happiness or a satisfaction to the deeper needs of man. It cannot be too plainly recognised, however, that to Jesus as to John the Kingdom of God was a Commonwealth of social justice and brotherhood. To Him the precepts of the elaborate code traditionally known as the law of Moses, were summed up under the one general principle of love to God and man, or love to God through man. There are some indications that even Jesus was not at first entirely free from the belief that the Kingdom when it came would be first and foremost for the benefit of the 
Jews, and only secondarily for the good of the human race as a whole. Thus, for example, when a $\mathrm{Ca}$ naanitish mother appealed to Him to heal her sick child, His reply was -

"I was not sent but unto the lost sheep of the house of Israel. . . . It is not meet to take the children's bread and cast it to the dogs" (Matt. xv. 24, 26; Mark vii. 27).

If Jesus really said this, it is clear that at this time the horizon of His interests was bounded by a desire for the welfare of Israel and Israel alone. Another instance of a somewhat similar kind is His saying on the occasion of His visit to the house of Zaccheus the publican -

"This day is salvation come to this house, forasmuch as he also is a son of Abraham" (Luke xix. 9).

He also organised a band of preachers to whom He gave the commission -

"Go not into any way of the Gentiles, and enter not into any city of the Samaritans, but go rather to the lost sheep of the house of Israel. And as ye go, preach, saying, The Kingdom of Heaven is at hand" (Matt. x. 5, 6).

In such utterances as these Jesus shows Himself to be a true child of His time and race. If $\mathrm{He}$ did not use the words here attributed to Him, it is remarkable that they should have been recorded at all, for they were not written until after the exclusiveness of early Christian preaching had 
been broken through under the influence of the Apostle Paul; to this we must refer again presently. If Jesus had from the first meant His message to be universalistic in scope, it is strange that His immediate followers should have been so slow to yield to the urgent representations of Paul, and to permit him to carry the gospel to people of nonJewish race. It might have been expected that the Galilean apostles should know the mind of Jesus better than a man who was not counted among His followers during His actual ministry. The presumption, therefore, is that at the beginning of His public life, at any rate, Jesus believed that the benefits of the Kingdom of God were to extend only to the Jewish people. What was to become of the rest of the world is not stated.

His disappointment with Judaism. - But as time went on, Jesus' attitude on this point apparently began to give way, owing to His disappointment at the reception of His message, first on the part of the religious leaders, and afterwards on that of the general public. It would not be correct to say that Jesus was from the first the leader of the common people against the aristocratic orders. That was not so; He began with the synagogue-goers, and had followers among the better classes. But this did not satisfy Him; He wanted to include the whole nation in the coming Kingdom, and therefore He deliberately went to the social outcasts, and bade them amend their lives and claim their share 
in Israel's common heritage. It is easy to see that this kind of teaching would frighten off the respectable classes, although for a time it might rouse considerable enthusiasm among the unprivileged. The truth is that no class seems to have understood Jesus. The orthodox thought that the benefits of the Kingdom would be ensured to those who had kept to the details of the Jewish law; the remainder of the population wanted a good time, just as they do to-day, and they thought they saw in what Jesus was saying the promise of such a good time in the near future. Both were materialistic, each in their own way, and therefore as time went on they rejected the ideas of Jesus, although the starting-point of those ideas was just that popular belief in the imminence of the Kingdom of God which was already so widespread. Some of the sayings of Jesus scattered throughout the synoptical gospels, show how deeply $\mathrm{He}$ felt this, and how great was His disappointment.

"The Kingdom of God shall be taken away from you and given to a nation bringing forth the fruits thereof " (Matt. xxi. 43). "And I say unto you, that many shall come from the east and the west, and shall sit down with Abraham, and Isaac, and Jacob, in the kingdom of heaven: but the sons of the kingdom shall be cast forth into the outer darkness: there shall be weeping and gnashing of teeth" (Matt. viii. II, I2; Luke xiii. 28, 29). "O Jerusalem, Jerusalem, which killeth the prophets, and stoneth them that are sent unto her! how often would I have gathered thy children together, even as a hen gathereth her chickens under her wings, and ye 
would not! Behold, your house is left unto you desolate. For I say unto you, ye shall not see Me henceforth, till ye shall say, Blessed is He that cometh in the name of the Lord" (Matt. xxiii. 37-39; Luke xiii. 34, 35).

It is quite likely that Jesus uttered words like these, considering the comparative failure of His work among His own people. The beginnings were auspicious enough, and the fame of Jesus appears to have for a while outstripped even that of John, and to have attracted the attention of King Herod himself, the potentate who had put John to death, and who now wondered if the new prophet were the old come back. Jesus failed to retain the enthusiasm of the populace, partly because of His moral intensity, which made too great a demand upon average human nature, and partly because of the disappointment when days and months passed and the expected national insurrection or Divine interference with the progress of events did not take place. We get a hint of this in the question said to have been sent by the Baptist from his prison -

Art thou He that cometh, or look we for another? (Matt. xi. 3; Luke vii. Ig).

Probably there were some even among the scribes and Pharisees who, in the heyday of the popularity of the Galilean teacher, were disposed to think of Him as the leader every one was looking for; but the only indication we have of such a feeling on 
their part is the somewhat doubtful testimony of the fourth gospel, where the author puts into the mouth of the Jews the interrogation: "How long dost Thou hold us in suspense? If Thou art the Christ, tell us plainly" (John x. 24). It is on the same slender foundation that we have the statement of the likelihood that at one time the people were about to take Him by force to make Him king. We are told in the same passage that they wished to do this, because they were convinced that $\mathrm{He}$ was, indeed, the prophet whose advent had been foretold (John vi. I4, I5). We can well understand that the reaction against Jesus would be in proportion to the intensity of popular belief in what might be expected from Him, and to the anger which was felt when time passed on and nothing was done.

Did He think of Himself as the Messiah? - But the question is important whether Jesus Himself took the view of His vocation which popular feeling did at the zenith of His fame, that is, whether $\mathrm{He}$ regarded Himself as the Messiah. On this point the gospel accounts are not clear. If Jesus had deliberately given out that $\mathrm{He}$ was the Messiah, a plain issue would have been declared at once, and every one would have expected a rising against Rome backed by portents from heaven. As it was, His reserve seems to have given opportunity for all kinds of speculation concerning His identity. All three of the synoptists tell us that He Himself asked His followers what people were saying about 
Him in this respect, and the answer was that various opinions were held.

"Some say John the Baptist; some Elijah; and others, Jeremiah, or one of the prophets" (Matt. xvi. I3, I4; Mark viii. 27, 28; Luke ix. I8, I9).

The same question elicited from His little group of followers the confession, "Thou art the Christ." It thus appears that even at an advanced stage in the ministry of Jesus - which, at the longest, was no more than three years - no public or private pronouncement had been made as to His Messiahship. Even now, the evangelists add, He cautioned His followers to say nothing about it. Later on, of course, this caution became quite useless, as is evident from the nature of His welcome into Jerusalem just before His arrest and crucifixion. Here again the evangelists are at one in their testimony. Jesus made a public entry into the city, and allowed the crowd to greet Him with the acclamation -

"Hosanna; Blessed is He that cometh in the name of the Lord; Blessed is the Kingdom that cometh, the Kingdom of our father David; Hosanna in the highest" (Mark xi. 9, 10; Matt. xxi. 9; Luke xix. 37, 38).

In Luke's version it is stated that some of the Pharisees tried to check the demonstration, and called upon Jesus Himself to forbid it, "and $\mathrm{He}$ answered and said, I tell you that, if these shall hold their peace, the stones will cry out" (Luke xix. 40). There is no mistaking the meaning of 
this salutation or Jesus' comment upon it. Whatever may have been His objection to allowing Himself to be called the Messiah at the beginning of His public ministry He had none now.

The most reasonable inference from the facts seems to be that it was only gradually that the probability that $\mathrm{He}$ was called to be the Messiah dawned upon Jesus' own mind. We may reject at once as unhistoric any gospel references to portents which declared the supernatural dignity of Jesus at His birth, or even at His baptism. Such early Christian hymns as the Magnificat and the Song of Simeon only came into existence long after the crucifixion. That $\mathrm{He}$ could have been proclaimed by the Baptist is impossible, taking into account the question already quoted. Besides, as we have seen, widely differing views concerning the character and endowments of the Messiah were current at this time, the one point of agreement being that $\mathrm{He}$ was to be the means of restoring the Kingdom to Israel and making it a Kingdom of God. How far Jesus shared the views of His time as to the supernatural accompaniments of the work of the Messiah we shall never know, but it seems to me in the highest degree probable that the very idea of Messiahship underwent some transformation in His mind. By this I mean that He thought of the Messiah as being above all things a spiritual force. He never made the slightest attempt in the direction of instituting the Kingdom by violence, and it 
is noteworthy that He only began to permit people to call Him the Messiah when the end of His ministry was in sight and $\mathrm{He}$ must have known that $\mathrm{He}$ stood in great danger. The evangelists are just as thoroughly agreed that $\mathrm{He}$ prophesied His own death at the hands of His enemies as that He allowed Himself to be called the Messiah. We cannot account for this in any other way than to say, as has often been pointed out, that Jesus took for His ideal the Suffering Servant of God, as described in the second Isaiah, especially in the well-known fiftythird chapter: "He is despised and rejected of men, a man of sorrows and acquainted with grief." To preach righteousness and die for so doing appeared to Him to be a truer kind of Messiahship than one of terrifying might and military glory.

The two Comings. - At the same time we must beware of going so far in the direction of conventional Christianity as to be certain that Jesus was so far ahead of His contemporaries as to be able to rely confidently upon the moral effect of a noble life, and trust to that alone to regenerate the world in time by the slow working of the Spirit of Truth. I do not think the Gospel accounts of the doings of Jesus warrant any such conclusion. If this were really the dominating thought in His mind it seems strange that $\mathrm{He}$ did not get any of His followers to understand it, for it is clear enough that the men who wrote the gospels thought something quite different about His intentions. According to them 
His idea was that there were to be two comings of the Messiah, and that the Kingdom would be established by the second coming, not the first. The statement is put into the mouth of Jesus that there would be a period of national tribulation intervening between His ministry and the grand consummation which He called the end of the age and the beginning of the new order. If Jesus really thought this it could only have been towards the end of His ministry when $\mathrm{He}$ saw that there was no likelihood of His being accepted by His countrymen. When He first began to preach, this thought found no place in His utterances; He declared the Kingdom of God to be quite near. Still, there does seem a probability that the thought came later, otherwise we cannot account for the certitude of the first Christians concerning the speedy return of their Lord.

\section{Thus -}

"And He began to teach them, that the Son of man must suffer many things, and be rejected by the elders, and the chief priests, and the scribes, and be killed, and after three days rise again. And He spake the saying openly" (Mark viii. $3^{\mathrm{r}}$ ).

In another part of this earliest gospel we read that "they understood not the saying, and were afraid to ask Him."

It certainly does seem strange that, if Jesus foretold His temporary failure and death with such clearness and emphasis, His followers should have been 
so utterly taken by surprise when the end came, and even up to the hour of His arrest, should have gone on expecting some sudden coup d'état in His favour. On the other hand, it may be that these supposed prophecies came into existence at a later time in accordance with the general Christian supposition that Jesus must have known all about His own death before it took place. Still I do not think that this hypothesis is altogether sufficient to account for their presence in the gospel narrative. It is not on the whole unlikely that Jesus may have come to believe such a thing possible, and to say so. When He read the second Isaiah He could not but feel the applicability to His own case of the description of the fate of the righteous servant who was at first to be rejected by his own people, and afterwards "see of the travail of his soul and be satisfied." Probably this description of the Suffering Servant of God was inspired by the recollection of what had been endured by Jeremiah before and in the period of the great captivity. This brave man had stood alone in his endeavour to dissuade the Jewish monarch and people from the course which finally led to their subjugation by Nebuchadnezzar. For doing this he had been ostracised by his contemporaries, treated with derision and hatred, imprisoned, maltreated, and, not improbably, murdered. When in after days his unfortunate countrymen looked back upon his warnings they reverenced his name as much as they had formerly execrated it, and, at the time 
when Jesus began His public ministry, Jeremiah was popularly referred to as the prophet in comparison with all other prophets. It was a high compliment to Jesus that some of the people who heard Him wondered whether $\mathrm{He}$ might be Jeremiah risen from the dead. In accordance with the thought of the second Isaiah, therefore, it was not unnatural that Jesus should think of the fate of Jeremiah as likely to be His own. He saw in what this man had done and endured a grander kind of Messiahship than that of contemporary expectation, and yet $\mathrm{He}$ saw no necessity for altogether abandoning the latter either. In His mind the two became interwoven, with the result that He came to accept as inevitable His temporary failure, and to look forward to subsequent success. Probably He came to this conclusion slowly and hesitatingly, even unwillingly. He had to reconcile Himself to the idea of dying a violent death at the age of thirtythree; but at the same time $\mathrm{He}$ assured Himself that that would not be the final chapter after all, for God would never permit evil to obtain the mastery. It is quite conceivable, therefore, that $\mathrm{He}$ thought of Himself as coming again in triumph from the further side of death to inaugurate the Kingdom. This may seem to some like the self-delusion of a young enthusiast, but surely it was something more: it was a firm reliance upon the working of the immutable laws of righteousness, and a confidence that in the long result good could not be worsted by evil. 
Where the idea of a resurrection on the third day came from we cannot be sure. Jesus may have used the expression or He may not; the notion is not peculiar to Christianity. It should not be regarded as an exact statement, but as a phrase expressive of the nearness of the triumph of good. Thus (Hosea vi. 2) we read: "After two days will he revive us; on the third day he will raise us up and we shall live before him."

This was the way in which, apparently, Jesus spoke towards the close of His ministry about what must have looked like the overthrow of all His hopes. And yet, as the record of His anguish of mind in the Garden of Gethsemane on the night of His arrest serves to demonstrate, $\mathrm{He}$ did not always succeed in convincing Himself that this course of events was for the best. His great soul recoiled from that last humiliation. It was only when it became inevitable that $\mathrm{He}$ surrendered Himself to it. Even then His confidence that all would come right in the end seems for a moment to have failed Him on the cross. The cry, "My God, my God, why hast Thou forsaken me?" needs no theological interpretation. It was a cry wrung from a breaking heart, and no wonder.

Jesus' idea of the Kingdom; i. His dualism. What, then, was the idea of the Kingdom which Jesus held and taught, and in what respect did it differ from that of His contemporaries? These are questions to $w^{\prime}$ a complete answer is impossible, 
for we have nothing to go upon except these fragmentary gospel records written long after the occurrences we have been examining. But, on the whole, to be honest, I feel we must admit that there is very little, if anything, which differentiates the essential teaching of Jesus from that of the other teachers of His time beyond the fact that it was simple and clear, and went straight to the root of the matter in hand. He never repudiated the Jewish law, but he did not hesitate to abrogate some of its precepts when they were out of harmony with His fundamental principle of love for God and man.

"Ye have heard that it was said, "Thou shalt love thy neighbour and hate thine enemy"” (Lev. xix. I8). "But I say unto you, Love your enemies, and pray for them that persecute you" (Matt. v. 44).

The force of a saying like this is best understood when it is remembered that to a Jew the enemy was the foreigner, and that at the moment the oppressor for whom they were thus exhorted to pray was the cruel Roman; nothing could be much more completely in contrast with the mood of the time than this particular utterance. But I do not care to inquire too minutely into the meaning of special sayings. The main difference between the teaching of Jesus and that of the orthodox instructors of the public was that the latter were always hair-splitting as to what was lawful and what was not, whereas Jesus penetrated straight to the spirit of the deed, 
whatever it might be. The inwardness of His ethical teaching stood thus in sharp contrast to the casuistry and niggling regulations of Pharisees and scribes. These laid stress upon ordinance and rule; Jesus upon spirit and motive. In other respects (according to the gospel writers) Jesus thought much the same as other people. His cosmogony was that of ordinary Judaism - Heaven just above the sky. Hades down below the surface of the earth. $\mathrm{He}$ believed in the popular dualism of the time about the essential opposition between the Kingdom of God in heaven and that of Satan on earth. He held that what the world needed was that Satan should be driven out thoroughly and speedily. He supposed that His special mission was to announce this coming overthrow. He believed, too, that all the ills which afflicted mankind, especially the people of God, were due to the wickedness of Satan and his host of evil spirits. Hence the first sign that God was about to put an end to the dominion of Satan was the fact that His messenger was able to perform miracles of healing. I have not the slightest doubt that a good many of such miracles took place, partly because of the magnetic personality of Jesus, and partly because people expected such things; plenty of similar supernormal events are taking place in our midst to-day. There is not much evidence that Jesus was greatly influenced by current pessimism concerning the manner of the entrance of evil into the world and the fixing 
of the yoke of Satan upon the necks of the chosen people; but there is a suggestion of it in the parable of the Tares, for example -

"The good seed are the children of the kingdom; but the tares are the children of the wicked one; and the enemy that sowed them is the devil" (Matt. xiii. 38, 39).

It is evident, too, that Jesus thought of certain forms of disease as the result of demon possession. When accused of casting out devils through the prince of the devils His reply was -

"If Satan casteth out Satan, he is divided against himself; how then shall his kingdom stand? . . . But if I by the Spirit of God cast out devils, then is the Kingdom of God come upon you" (Matt. xii. 26, 28).

On another occasion, according to Luke, when healing a woman who "was bowed together, and could in no wise lift herself up," He was called to account by the ruler of the synagogue for disregarding the Sabbath. His defence was -

"Ought not this woman, being a daughter of Abraham, whom Satan had bound, lo, these eighteen years, to have been loosed from this bond on the sabbath day?" (Luke xiii. 16$)$.

ii. His eschatology. - It seems probable, also, that Jesus fully accepted the ordinary Jewish eschatology of the time:

"The harvest is the end of the world (or, literally, the consummation of the age); and the reapers are angels. As therefore the tares are gathered up and burned with fire; 
so shall it be in the end of the world. The Son of man shall send forth His angels, and they shall gather out of His kingdom all things that cause stumbling, and them that do iniquity, and shall cast them into the furnace of fire: there shall be weeping and gnashing of teeth. Then shall the righteous shine forth as the sun in the kingdom of their Father" (Matt. xiii. 39-43).

Equally emphatic is the parable of the Last Judgment, as it is usually called, but which is certainly not a last judgment in the theological sense of the word:

"When the Son of man shall come in His glory, and all the angels with Him, then shall $\mathrm{He}$ sit on the throne of His glory: and before Him shall be gathered all the nations: and He shall separate them one from another, as the shepherd separateth the sheep from the goats: and He shall set the sheep on His right hand, but the goats on the left. Then shall the King say unto them on His right hand, Come, ye blessed of my Father, inherit the kingdom prepared for you from the foundation of the world. . . . Then shall He say also unto them on the left hand, Depart from $\mathrm{Me}$, ye cursed, into the eternal fire which is prepared for the devil and his angels" (Matt. xxv. 3I-34, 4I).

There is no need to suppose that Jesus actually uttered these words as they now stand; in fact, it is quite probable that $\mathrm{He}$ did not, for there is a universalism about them which did not find a place in primitive Christian preaching. There is no suggestion here that the Jews would be treated any differently from other people when the Kingdom came, so the present form of the parable must 
date from a time subsequent to the fall of Jerusalem in A.D. 70. It should be clearly understood that this kind of a judgment was not really the end of the world at all; it was the purification of the world and the beginning of a brighter and better day for the righteous. The externals of the judgment as here described are taken directly from the Book of Daniel, and are quite in keeping with the spirit of the ordinary Jewish apocalyptic literature of the period in which it arose. But the truly remarkable thing about the parable is the criterion it presents of the qualification which would be required for membership in the Kingdom of God. That qualification was goodness, and the goodness referred to was not the righteousness of scribes and Pharisees, which consisted in rendering formal obedience to the prescriptions of the Jewish law, but a goodness which showed itself in works of mercy and compassion to suffering human kind. It is here that I seem to hear the voice of Jesus. Not a word about belief; not a word about correctness of creed; not a word about piety; not a word even about the duty of confessing the Master Himself, a duty in which the primitive Christians certainly believed with all their hearts. But -

"Lord, when saw we Thee hungry, and fed Thee? or thirsty, and gave Thee drink? And when saw we Thee a stranger, and took Thee in? or naked, and clothed Thee? And when saw we Thee sick, or in prison, and came unto Thee? And the King shall answer and say unto them, 
Verily I say unto you, Inasmuch as ye did it unto one of these My brethren, even these least, ye did it unto Me" (Matt. xxv. $37-40$ ).

The framework of the parable is the ordinary Jewish ideas of the time about the coming of the Son of man on the clouds of heaven and the shutting of the wicked down in Hades. This is what everybody thought, and there is no more reason to attribute it to Jesus than to any one else. But the central truth of the parable, the truth concerning the genuine test of righteousness, was not what everybody thought; and it is, therefore, not unreasonable to inferr that this is the part of the parable in which we have the teaching most characteristic of Jesus.

iii. His moral intensity. - There is thus no documentary evidence that Jesus transcended the level of His time in His religious beliefs, but $\mathrm{He}$ charged those beliefs with a moral passion which had long been wanting to them, and it was this which in the end brought Him to the Cross. He said not a word, nor produced an idea, which in some form or other had not found expression before; but He refused to have anything to do with mere formalism, cant, or pretence. He did not compromise; He would not speak evil doers fair merely because they were powerful. $\mathrm{He}$ attempted to apply His own principles consistently all the way round, and the result was that $\mathrm{He}$ had to be silenced. He saw that as things then were the poor and the 
weak had to go to the wall; the rich and the strong had things all their own way. What made Him most angry was not the doings of the Roman conqueror, but of the hypocritical religious leaders of His own race. He did not begin by saying this. On the contrary, He seems to have hoped to win them, and there is an observable difference in the style of His earlier as compared with His later preaching. It was only when $\mathrm{He}$ found that His endeavours were thwarted by the orthodox religious orders that $\mathrm{He}$ broke out in stern denunciation against them. It seems to me that at first $\mathrm{He}$ thought everybody would listen gladly to what $\mathrm{He}$ had to say about the good time that was coming for Israel, and prepare themselves accordingly. $\mathrm{He}$ declared that in the new Kingdom there could be no more question of precedence and pride of place. The one indispensable requisite for inclusion in the new order would be humility and childlikeness of spirit. There could be no possibility of a happy world without this, and yet this was the very opposite of the temper of respectable Jewish religion in that day. He illustrated this principle by His parable of the Pharisee and the publican, and by His beautiful action in taking a little child and setting him in the midst of a company of jealous and angry men, saying at the same time -

"Whosoever shall not receive the Kingdom of God as a little child, he shall in no wise enter therein" (Mark X. 15).

Again - 
"Ye know that they which are accounted to rule over the Gentiles lord it over them; and their great ones exercise authority over them. But it is not so among you; but whosoever would become great among you, shall be your servant; and whosoever would be first among you, shall be the bondservant of all" (Mark x. 42-44).

It is obvious that in this He was perfectly right. An ideal world is impossible so long as men are arrogant, domineering, or jealous of one another. If the conditions could be eliminated out of which such desires arise, we should have secured the first essential of communal happiness.

iv. His views on the possession of riches. Observing, also, as $\mathrm{He}$ could not fail to do, the corrupting influence of the possession of wealth upon the moral nature Jesus condemned utterly the desire for its acquisition. This is best illustrated in the story of His recommendation to the rich young ruler:

"Go, sell whatsoever thou hast and give to the poor, and thou shalt have treasure in heaven; and come, follow Me" (Mark X. 2I).

It is quite useless to maintain, as has sometimes been done, that Jesus did not mean this as a counsel of universal application. The whole background of His teaching shows that $\mathrm{He}$ did. He does not say that the possession of riches is an absolute disqualification for membership in the coming Kingdom, but he holds that at the best they are a hindrance, for they tend to put a 
barrier of separation between man and man; the ideal social order would therefore be one in which there would be no question either of poverty or riches. Moreover, Jesus is severe upon the typical rich man, for, not without reason, $\mathrm{He}$ saw in him the oppressor of the poor. In the parable of Dives and Lazarus $\mathrm{He}$ does not specify any particular offence of which the rich man had been guilty, but He sends him to Hades (Luke xvi. r9-3I). In Luke's version of the Sermon on the Mount, too, the first beatitude is -

"Blessed are ye poor; for yours is the kingdom of God" (Luke vi. 20).

There can be little doubt that this was the original form of the utterance. Matthew's gospel has been not inappropriately styled the ecclesiastical gospel on account of its tendency to improve the occasion in the manner with which we are so familiar in pulpit exhortations to-day. Luke is frankly socialistic in his way of presenting the Master's words; he is always thinking of the poor, their disabilities, and their sorrows. Probably the first and third gospels both drew upon the same literary source in their presentation of the body of teaching comprised in the beatitudes and their immediate context, but, if so, the difference in emphasis is surprising. Where Matthew talks about hungering and thirsting after righteousness, Luke bluntly says - 
"Blessed are ye that hunger now; for ye shall be filled" (Luke vi. 2I).

Matthew speaks of the reward of the righteous, but Luke announces the doom of the wealthy.

"Woe unto you that are rich! for ye have received your consolation. Woe unto you, ye that are full now! for ye shall hunger. Woe unto you, ye that laugh now! for ye shall mourn and weep" (Luke vi. 24, 25).

If this be the way in which Jesus really preached, the spectacle of the social inequalities of the time must have moved Him profoundly. His picture of the social upheaval which $\mathrm{He}$ believed to be just at hand included vengeance upon the whole class of the rich. Plainly He was on the side of the poor, and looked at the rich very much as the leaders of the French democracy looked at the aristocrats at the beginning of the Revolution. He declared it to be easier for a camel to go through the eye of a needle than for a rich man to enter into the Kingdom of God. His general attitude on this point was not modified in the least by the fact that $\mathrm{He}$ had one or two rich adherents, such as Joseph of Arimathæa. These were exceptions; there is only too much probability that the strictures of Jesus upon the holders of wealth were more than justified at the time.

v. His censure of the religious leaders. - But it was upon the covetous and grasping religious aristocracy that His denunciations fell most heavily. 
In all the literature of invective I know nothing more scathing than His attack on this order as recorded in Matthew xxiii. The whole chapter is quotable and absolutely to the point, but the following verses express most fully its spirit and intention:-

"Woe unto you, scribes and Pharisees, hypocrites! for ye shut up the kingdom of heaven against men; for ye neither go in yourselves, neither suffer ye them that are entering to go in.

"Woe unto you, scribes and Pharisees, hypocrites! for ye devour widows' houses, and for a pretence make long prayers; therefore ye shall receive the greater damnation.

"Woe unto you, scribes and Pharisees, hypocrites! for ye compass sea and land to make one proselyte, and when he is made, ye make him twofold more a child of hell than yourselves.

"Woe unto you, scribes and Pharisees, hypocrites! for ye tithe mint and anise and cummin, and have left undone the weightier matters of the law, judgment, and mercy, and faith; but these ye ought to have done, and not to have left the other undone. Ye blind guides, which strain out the gnat, and swallow the camel. . . .

"Woe unto you, scribes and Pharisees, hypocrites! for ye build the sepulchres of the prophets, and garnish the tombs of the righteous, and say, If we had been in the days of our fathers, we should not have been partakers with them in the blood of the prophets. Wherefore ye witness to yourselves, that ye are sons of them that slew the prophets. Fill ye up then the measure of your fathers. Ye serpents, ye offspring of vipers, how shall ye escape the judgment of hell!"

Strong language this! One wonders what the religious press of this country would say about it 
nowadays. For the people thus denounced have their representatives in the Christian churches of this much-favoured land of ours. But what chiefly impresses me about the use of this language is that it gives us an entirely different idea of Jesus from that which is usually held up for Christian adoration and imitation. Here was a being aflame with sympathy for the masses and indignation for their oppressors. It is no use saying that $\mathrm{He}$ was not alive to the social wrongs of the age, for $\mathrm{He}$ was, and this language proves it. It shows what brought Him to His death; it shows, too, why the orthodox hated and feared Him. Not that He pandered to the multitude; He never did that. But with His whole soul He loathed the self-complacency of the ordinary religionists who were content to be on the side of privilege without lifting a finger to help the unprivileged, and yet talked about righteousness! What would Jesus say if He were to appear in our midst again to-day? Can there be much doubt about the matter? Are we still doing the same thing - talking about righteousness as though it could be separated from social justice? Of course we are, and the hollow sham will have to come to an end.

That Jesus thought the end was coming very speedily is not surprising, and is no sign of credulity on His part. There are people in Russia talking much the same way to-day, and perhaps they too may prove to be wrong. Jesus had been trained to 
think that the Kingdom of God could not be very far off. It was only when He saw that the moral forces of the hour had become concentrated in His own person that $\mathrm{He}$ began to believe that $\mathrm{He}$ was the divinely appointed deliverer through whom it should come. How $\mathrm{He}$ expected God to interfere we do not know. The most probable explanation appears to be that when $\mathrm{He}$ saw failure staring Him in the face He looked forward to a second advent in which $\mathrm{He}$ should be accompanied by legions of angels for the overthrow of the kingdoms of this world. What $\mathrm{He}$ has actually accomplished in human history has proved to be far greater, for His faith in the God of righteousness has become the dynamic of most of the great achievements that have been effected for the emancipation of the human race from the bondage of iniquity during the past fifteen hundred years. Take Jesus out of western history, and what would be left? I deny that Jesus belongs or ever has belonged to the ecclesiastical order and the forces of conservatism in Church and State. He belongs to the democracy, and the democracy has never quite lost sight of the fact. The words which Mark Rutherford puts into the mouth of the agitator Caillaud appropriately express the true significance of the character and work of Jesus -

"What said Jesus - that He came to send a sword? Of course He did. Every idea is a sword. What a God He was! He was the first who ever cared for the people - for the real 
people: the poor, the ignorant, the fools, the weak-minded, the slaves. The Greeks and Romans thought nothing of these. I salute Thee, O Thou Son of the People!" and Caillaud took down a little crucifix which, strange to say, always hung in his room, and reverently inclined himself to it. "A child of the people," he continued, "in everything - simple, foolish, wise, ragged, Divine, martyred Hero."

With all this we may without hesitation recognise the omissions of Jesus even in the expression of His own ideals. It would be ridiculous to call Him a Socialist, in the ordinary everyday use of that word, for He had no economic theory whatever; it is unlikely that He ever felt the need of any. He laid down no principles for the guidance of His followers in their social relationships, marriage, the family, and citizenship. His belief in the approaching disruption of the existing social order, and the substitution of another by supernatural means allowed little room for theorising. He even seems to have thought that marriage and procreation would be at an end with the establishment of the Kingdom of God, although that establishment was to take place on earth.

"For in the resurrection they neither marry, nor are given in marriage, but are as angels in heaven" (Matt. xxii. 30). "For as in those days which were before the flood they were eating and drinking, marrying and giving in marriage, until the day that Noah entered into the ark, and they knew not until the flood came, and took them all away; so shall be the coming of the Son of man" (Matt. xxiv. 38, 39).

This view as to the future coexisted in His mind 
with strong and definite opinions concerning the sacredness of the marriage bond under present conditions. The same anticipation of the break-up of social relations led to His forbidding care for the morrow, a perfectly impossible maxim for presentday civilisation; for, no doubt, Jesus meant that it was not worth while to pay much attention to the present, seeing that the great change was so imminent. He gave no hint as to what kind of laws there would be in the new order, or whether there would be any laws at all. He submitted to paying taxes to the Roman power, because $\mathrm{He}$ was convinced that it would not be for long, and in any case there were wrongs that needed to be righted in the very constitution of Jewish society independently of Roman rule. He said nothing about the dignity of labour, or the right of the worker to the product of his labour. He had a sense of natural beautyquite in contrast with that of the Apostle Paul, for instance, who passed through some of the most beautiful districts in the world in the course of his missionary journeys, and never says a word about them - but $\mathrm{He}$ did not show either sympathy or acquaintance with Art. Of philosophy and science He knew nothing. The only literature $\mathrm{He}$ quotes is that of Israel. $\mathrm{He}$ paints no pictures of the future at all comparable to Mr. Bellamy's "Looking Backward," or Mr. H. G. Wells's "Modern Utopia." No, He leaves the future entirely to God; drafts no constitutions, and elaborates no schemes of industrial 
organisation. Nothing could be simpler and more inchoate than the social ethics of Jesus. We cannot accept them in their entirety and without question, for they leave whole regions of modern life untouched. But the one outstanding fact upon which there cannot be two opinions is the fact that Jesus preached an ideal social order on earth when He preached the Kingdom of God, and that He was driven to do so by His clear perception of the ills under which His countrymen suffered in a time when justice for the oppressed was seldom to be had.

To sum up. We have seen that Jesus was to a large extent the product and inheritor of a long historic tradition. He came into an environment where expectation concerning the Kingdom of God was already widespread, and had certain definite ideas attaching to it which $\mathrm{He}$ was able to take for granted in addressing the Jewish public. There were many who thought that the Kingdom of God, as popularly understood, "should immediately appear" (Luke xix. II). He took up and continued the work of a great preacher whose message was based on this assumption. He shared, apparently, in the ordinary belief of His time and race that the Kingdom would come suddenly and supernaturally, and would mean the restoration and exaltation of the Jewish theocracy of earlier days; later on $\mathrm{He}$ modified this belief, because of His disappointment at the materialism of the people 
to whom $\mathrm{He}$ preached. $\mathrm{He}$ wished His hearers to understand that the Kingdom would be one of social and individual righteousness, peace, and brotherhood, "on earth as it is in heaven." It was some time before He permitted Himself to be called the Messiah, and He introduced a new element into the conception, namely, that the deliverer would have to suffer in the discharge of His vocation. At the close of His ministry $\mathrm{He}$ seems to have come to face the fact that He would be rejected and put to death, and therefore that His work could only be consummated by a second advent, which would be exactly like what popular expectation had already pictured concerning the coming of the Messiah. He believed that after the judgment which would then ensue "the meek should inherit the earth." Membership in the new Kingdom would be the prerogative of those who were humble in spirit and poor in substance; He considered that there was small prospect of any rich man being able to qualify for it. He fell foul of the religious leaders of the time on account of their formalism, hypocrisy, and covetousness, which permitted them to call themselves righteous without being just and neighbourly in their dealings with the oppressed and unprivileged. His view of the structure of the universe was that of His time, as was His belief that "the prince of this world" was the prime author of all the sufferings of humanity. To Him the whole cosmic drama was a conflict between 
God and Satan, in which Satan was triumphant for the moment, but would be overthrown when the Kingdom came with power. $\mathrm{He}$ was convinced that His own temporary failure was permitted by God in order to fill up the measure of the wickedness of Satan and his human servants: "This is your hour, and the power of darkness" (Luke xxii. 53). He had no economic theories; no interest in industrialism; and laid down no directions for the administration of the ideal State, or the guidance of the individual in his social relationships; His idea was supernatural revolution, not social evolution. But the one undeniable and all-important fact about the preaching of this greatest of the sons of men is that it was inspired by a profound belief in the coming of a better day and an ideal human society on earth. He never says a word about going to heaven, for the plain and simple reason that all His hopes were bound up with the realisation of heaven here. His illusions were those of the period in which, and the people among whom, He did His work; His ideal is for all time, and is the inspiration of all that is best and noblest in human aspiration and effort to-day.

One thing must not be lost sight of. The probabilities are that Jesus was far greater than the reporters of His words have been able to show. I feel that $\mathrm{He}$ could not really have been as largely influenced by local and temporary conditions as the gospel records make it appear. But we have 
no other evidence to go upon, and the gospels have at least the inestimable value of showing us where the dynamic of the Christian religion came from, and what it was that the followers of Jesus were aiming at. Christianity was the product of ascertainable social and intellectual conditions. Its objective was the deliverance of mankind from the power of all that makes life dark and sad. It had no other objective; and, if the social attritions of the time in which it arose had not produced a crying sense of need, the new gospel would never have had a hearing at all. The words of Jesus as recorded in the first three gospels are a mirror of the mind of the humble evangelists who first preached Christianity in the streets of Jerusalem and in the Græco-Roman world. 


\section{CHAPTER IV}

\section{THE KINGDOM OF GOD}

\section{In Primitive Christianity}

Nationalism of primitive Christianity. - We now come to the consideration of the place which the Kingdom of God occupied in apostolic preaching, and the reason why it continued to be associated with the name of Jesus, although Jesus Himself had apparently been silenced in a most cruel and tragical fashion. The first thing to be clearly understood in this connection is that the primitive Christians thought almost precisely what the Jews did about the Kingdom and the manner of its coming. The one great point of difference between Jew and Christian was that the latter declared Jesus to be the Messiah, whereas the former contemptuously maintained that $\mathrm{He}$ was not. In practically all other respects their views and expectations were identical. The Christians did not know that they had a new religion; they supposed themselves to be loyal Jews, just as the Methodists eighteen centuries later supposed themselves to be orthodox members of the Church of England until they were turned out of it. There was one conspicuous differ- 
ence between orthodox Judaism and the Judaism of the followers of Jesus; the former was dis-spirited and morally powerless, while the latter was full of enthusiasm and spiritual energy. We have already seen that what chiefly differentiated the preaching of Jesus from that of the ordinary religious teachers of the time was the moral passion that informed it; exactly the same difference is observable between Jews and Christians in New Testament times.

The followers of Jesus did not call themselves Christians; they never thought of such a thing. We read that "the disciples were called Christians first in Antioch" (Acts xi. 26), but we do not read that they ever voluntarily assumed the name. Like the terms Quaker and Puritan, the name "Christian". was at first fastened upon its wearers as a sort of popular nickname, by which they were distinguished from ordinary folk. Even then the name could not have been one which took its rise in Jewish circles, for, literally construed, it meant believers in or followers of the Messiah. No orthodox Jew could admit for a moment that the adherents of an executed criminal were genuine believers in the Messiah. Thus the very name is an indication that the new religion very early broke its way through the exclusiveness of ordinary Jewish religious ideas. It is not to be supposed that such an important departure could have been made without struggle and hesitation, and when we come 
to examine New Testament literature in the light thrown upon it by modern historical criticism, we can see that the struggle and hesitation must have been considerable. The step thus taken was most momentous in its after effects, for it made possible the transformation of the new religious society into a world-wide organisation which has survived the decay of one great civilisation, and become the guiding influence in the rise of another which is still vigorous, and bids fair to become universal. That this step was ever taken at all was due principally to the energy of one man, Saul of Tarsus, better known as the apostle Paul. But for Paul Christianity would have struggled on for a while as a small Jewish sect and then disappeared from history; that is, unless its moral power might have been continued such as to break through all barriers of national prejudice.

The situation at the death of Jesus. - But our chief concern at present is with the gospel which these first Christians believed they had to preach. We shall see as we proceed that Paul had some influence upon that also, and not wholly for the best. In order that we may understand how this came about, let us briefly examine the situation as it appeared to the followers of Jesus when their Master had been put to death. Naturally enough, their first feeling must have been one of utter consternation. The little group of Gali- 
leans who had accompanied Him on His last journey to Jerusalem did so in the confident expectation that something portentous would take place there, perhaps a public and national recognition of the Messianic dignity of Jesus. True, they had some misgivings on the subject, if we are to credit the Johannine reference to the anxiety they are said to have felt for His safety in the great capital. "Master; the Jews of late sought to stone Thee, and goest Thou thither again?" But we may take it as fairly certain that their simple-hearted enthusiasm for their leader led them to form the most extravagant anticipations concerning the crisis which they supposed to be at hand. They even began to compete with each other for positions of authority in the new order which should follow the upheaval. They wanted to be great officials. "Grant that these my two sons may sit, the one on Thy right hand, and the other on the left in Thy kingdom," was a fond mother's prayer (Matt. xx. 2I). Jesus did not rebuke the matter-of-fact nature of this kind of expectation, although he forbade selfish ambition. On the contrary, $\mathrm{He}$ seems to have encouraged it:

"Ye are they which have continued with Me in My trials; and $I$ appoint unto you a kingdom, even as My Father appointed unto $\mathrm{Me}$, that ye may eat and drink at My table in My kingdom; and ye shall sit on thrones judging the twelve tribes of Israel" (Luke xxii. 28-30).

Could anything be more realistic? Already they 
were partitioning out the great offices of State among themselves! The triumphal entry into Jerusalem would go far to confirm their vivid belief in the golden future, and nowhere is this belief more clearly. expressed than in the account of what took place at the Passover celebration in the upper room - the Last Supper, as it afterwards came to be called:

"I will not drink henceforth of this fruit of the vine until that day when I drink it new with you in My Father's kingdom" (Matt. xxvi. 29).

Sayings like these show how strong and assured was the belief of these simple men that some stupendous revolution was about to take place. That they should think of themselves as fitted to occupy such exalted stations as are here indicated is somewhat pathetic, and shows how little they knew of the great world of which Rome was the centre. When they actually saw their Master helpless in the hands of His enemies; when they heard of the derision and cruelty to which $\mathrm{He}$ had been exposed; when their women returned from watching the dreadful scene on Calvary, their disillusionment must have seemed complete. The very description of the sufferer, affixed to the cross by the orders of the Roman governor, was a mockery of their hopes - "This is Jesus the King of the Jews" (Matt. xxvii. 37). What an ending to a glorious dream! Here were they, far from home, rustic strangers in the 
great centre of Jewish nationality, and their leader was dead, slain by the very powers they had thought Him about to overthrow. How could it be otherwise than that terror and bewilderment should have taken the place of the ardent optimism of a few days before? No sadder sentence was ever uttered than that which is put into the mouth of Cleopas and his friend on the journey to Emmaus on the third day after the tragedy: "We trusted that it had been He which should have redeemed Israel" (Luke xxiv. 2I).

The revival of enthusiasm through belief in the Resurrection. - When these circumstances are taken into account it becomes evident that something extraordinary must have taken place in order to reawaken in these Galileans the expectation which had been buried in the tomb of Jesus. I do not propose to enter into a discussion of the vexed and intricate problem of the resurrection of Jesus further than to say that in my judgment something supernormal must have taken place before these terror-stricken followers of the Master could be transformed into the heroes they later showed themselves to be. I may say at once that none of the explanations which reject utterly the story of the empty tomb appear to me to meet the case. By some means these men must have become convinced beyond all possibility of doubt that their Master was still alive, and that His final triumph was only postponed. I admit that it is impossible to reconcile the various New 
Testament accounts of the post-resurrection appearances of Jesus, but that does not invalidate my contention that His followers must have believed they had seen and conversed with Him after His death and burial. Ignorant peasants may perhaps be induced to believe anything, but they do not ordinarily behave with the moral exaltation which characterised the doings of the apostolic band within a short time after the crucifixion. Something must have happened. Is it altogether incredible that the familiar and beloved voice spoke once again from the further side of the great silence, and made it plain to the grief-stricken little community that the grave is not the last word, and that evil has no real power to overthrow anything that is of God? Perhaps we may be nearer than we think to a scientific demonstration of the fact that self-consciousness does not perish with the dissolution of the physical body. Without, therefore, entering upon a defence of any particular theory of the resurrection of Jesus, let me emphasise the conclusion that the first Christians must have believed it with all their hearts; and they believed it to be a physical resurrection, for the simple reason that they had no conception of an existence apart from the body. This statement opens a subject I have not yet touched upon, but it must not be passed over if we are to understand apostolic preaching, and particularly that of the apostle Paul. We shall lose nothing by pausing upon this point for a moment; on the 
contrary, we may gain something in additional clearness.

The doctrinal epistles. - New Testament criticism is at present in the melting pot, and it would be a foolish proceeding to hazard any confident theory as to the authorship and date of any or all of the various writings which have been admitted into the canon. But, as has been already indicated, the main importance of these writings, so far as our present purpose is concerned, is the general idea they give as to the subject-matter of primitive Christian preaching. If it should turn out that the various letters ascribed to Paul, for instance, every one belong to the second century instead of the first, this will not render them valueless from our point of view. It may be that Saul of Tarsus, whose conversion, and some of whose Christian activities are recorded in the Acts of the Apostles, ought not to be identified with the Paul who wrote Romans and Galatians; but, whether or no, these documents furnish most illuminating evidence as to the way in which the new evangel began to be modified in its Græco-Roman environment. We now begin to find the purely moral and social bearing of the original message mixed up with a somewhat elaborate theology, partly derived from Jewish rabbinism and partly from Greek philosophy. This was something quite new. Jesus Himself appears to have had no theology whatever, or if He had, it was of the simplest. His sympathies and interests were 
entirely practical, although based upon an invincible belief in the wisdom and goodness of God. What He wanted, and fully expected to see realised, was an ideal Jewish Commonwealth. The theological conceptions afterwards associated with His person and work, especially in the Pauline epistles, were utterly foreign to His mind, and would probably have been quite incomprehensible to Him.

The supposed connection between sin and death. The first of these ideas was the assumption that pain, sorrow, and death entered the world because of sin. There is no hint of anything of the kind in the words ascribed to Jesus, to whom, indeed, such speculation would have seemed to be beside the mark. Jesus never propounded riddles as to how trouble and suffering had come upon His countrymen; His problem was how to get rid of them. Looking into the past of the Jewish people, $\mathrm{He}$ could see reason enough why things had gone wrong, and $\mathrm{He}$ did not waste time in speculating as to what the sin of a primitive ancestor might or might not have had to do with it. But in the Pauline theory of things this was the very startingpoint. According to this view the world was an ideally perfect place to live in until by some unspecified act of transgression on the part of the progenitors of the human race the whole scheme had become disordered. We have already seen how this idea arose in the pessimism of the age immediately preceding the advent of Christianity. 
The name Adam is rather vaguely used in the Pauline writings to signify the individual or generation whose disobedience to the will of God had brought so many miseries in its train. This is explicitly stated in several of the best known passages in these Pauline writings. For example:

"Through one man sin entered into the world, and death through sin; and so death passed unto all men, for that all sinned" (Rom. v. I2).

According to this view it is evident that the principal part of the blame for the way in which things have gone wrong should rest with this primitive ancestor, whoever he may have been. But in apostolic thought there also appears to have been present the assumption that this primal act of transgression was like the opening of Pandora's box; it did not actually create evil, but opened the door to it. The real author of evil, or personal principle of evil, was the "prince of the power of darkness," or "prince of this world," or "prince of the power of the air, the spirit that now worketh in the children of disobedience," as he is variously called. We have already seen that this conception was probably derived from the influence of Persian dualism upon Jewish popular religion. Apparently, therefore, Adam was partly a criminal and partly a victim. In disobeying God he placed himself and the whole earth-world under the empire of 
Satan, who henceforth became the ruler of it. Pauline thought does not seem to have been consistently clear as to how much of the suffering of mankind was due to the displeasure of God and how much to the malice of Satan, but the main point upon which it insists is that the primal act of disobedience gave Satan his opportunity, and introduced discord and death to a world in which neither of them would otherwise ever have been known. What we see now is not creation as God meant it to be, but creation as Adam and Satan between them have managed to pollute it. Apparently, but for that original act of self-will on the part of Adam, neither he nor his descendants would ever have had to die at all, they would just have gone on living for ever and ever in a perfectly happy world.

How the Messiah was thought to have conquered sin and death. - It follows from this that the first thing to be done in order to get the world right would be to break this spell which Adam's disobedience had cast over the whole human race. The plot is not unlike that of the children's fairy stories, where the prince has been turned into a beast by the enchantments of some wicked ogre. In this case humanity is the prince, and the devil is the ogre; what was wanted was that some one should break the spell under which all men were doomed to suffer and die. According to the Pauline system, this want was supplied by the coming of Jesus 
Christ into the world. The Pauline writers identify Jesus with the Logos, or divine man, or Demiurgus of Philonic thought. This mighty one came down from the heaven just above the sky, was miraculously born into the world, grew up like an ordinary man, wrought many miracles, and then submitted to death as all human beings had had to do since Adam's fall. His soul went down into Hades like those of other people, but there was this difference between Him and other people, that, being sinless, death could not hold Him as it held ordinary mortals; He rose again from the tomb, resumed His body, and went up again into heaven in full view of His wondering disciples. But what $\mathrm{He}$ achieved by means of all this was very important. If $\mathrm{He}$ had not taken human flesh, lived a human life, and died a human death, He would not have been able to identify Himself with human lot, and so we should still have had to go on living individually our few suffering years, and then passed down for ever into the gloom and silence of Hades. But because Jesus did all these things, especially submitting to the death penalty, which was the wages of sin, $\mathrm{He}$ became the representative of mankind in severing the entail of sin and breaking the power of death. It was absolutely necessary that $\mathrm{He}$ should rise from the dead in order to do this, and it would have been of no use for Him to appear as a ghost; He must conquer this world by resuming 
His physical body in the very region where Satan had hitherto been master. His going up into heaven would only be for a short time. Presently He would come back again with all the power of heaven behind Him to call all the dead out of Hades, institute a general judgment, break up Satan's kingdom, drive all the wicked out of the earth and shut them down in Hades, and then establish that Kingdom of God for which so many of the faithful had been longing for ages. Let us look at some of the language in which this general view is set forth or taken for granted. Thus -

"For as through the one man's disobedience the many were made sinners, even so through the obedience of the one shall the many be made righteous" (Romans v. I9).

In this familiar passage the view taken is that in submitting to physical death Jesus had somehow satisfied the justice of God on behalf of the whole human race, physical death being the divinely ordained sentence upon sin. All that men have now to do is to claim the benefits of this Atonement. It should be clearly noted that it is not the future hell of present day popular religion from which this Atonement is supposed to save us, but from death itself, as well as all the existing pain and anguish of the world. The great thing to be done was to stop people from suffering and dying, and to cleanse the world from all the things that made 
men wretched. The initial step was taken in this direction when the Son of God underwent the pains of death Himself, and then rose triumphant over it. The spell of evil was now broken, and a great many other desirable things would shortly follow. Before very long this resurrection would become general in virtue of this victory of Christ over the devil, and those who were worthy would forthwith be endowed with immortality. This is the plain and simple meaning of such language as the following -

"Christ being raised from the dead dieth no more; death hath no more dominion over Him" (Romans vi. 9).

"Now hath Christ been raised from the dead, the first fruits of them that are asleep. For since by man came death, by man came also the resurrection of the dead. For as in Adam all die, so also in Christ shall all be made alive. But each in his own order; Christ the first fruits, then they that are Christ's, at His coming. Then cometh the end, when He shall deliver up the kingdom to God even the Father; when he shall have abolished all rule and all authority and power. For $\mathrm{He}$ must reign till $\mathrm{He}$ hath put all His enemies under His feet. The last enemy that shall be abolished is death" (I Cor. Xv. 20-26).

This passage means exactly what it says, and is about as good an example as could be found of the early admixture of Græco-Jewish superstitions with the simple ethics of Jesus. Another which ought not to be passed over in this connection is the well-known verse (Romans viii. II) - 
"If the Spirit of Him that raised up Jesus from the dead dwelleth in you, He that raised up Christ Jesus from the dead shall quicken also your mortal bodies through His Spirit that dwelleth in you."

Here the assertion is that the followers of Jesus are to be made immortal, not by dying and going to some distant heaven, but by having their physical bodies transformed in such a way that they will never again be subject to death. When the divine revolution takes place, and the kingdom comes, the new order will not be complete if death is still able to cause trouble and heartbreak, so there will be no more death. This is going a long way beyond anything that any modern social reformer has ever dreamed of. The same statement is even more plainly made in the following passage, with the additional assertion that some of those addressed would live to see it -

"We shall not all sleep, but we shall all be changed, in a moment, in the twinkling of an eye, at the last trump: for the trumpet shall sound, and the dead shall be raised incorruptible, and we shall be changed. For this corruptible must put on incorruption, and this mortal must put on immortality. But when this corruptible shall have put on incorruption, and this mortal shall have put on immortality, then shall come to pass the saying that is written, Death is swallowed up in victory" (I Cor. Xv. 5I-54).

The nearness of the second coming. - It is evident, too, that the general expectation among the Christians of the apostolic age was that it could not be 
long at the farthest before this dramatic second coming of Christ, with all its supernatural accompaniments, took place. Here is the programme according to one of the earlier of these epistolary writings -

"For the Lord Himself shall descend from heaven with a shout, with the voice of the archangel, and with the trump of God. And the dead in Christ shall rise first: then we that are alive, that are left, shall together with them be caught up in the clouds to meet the Lord in the air, and so shall we ever be with the Lord" (I Thess. iv. I6-I8).

How astonishingly remote is this naïve expectation from all that we are accustomed to at the present time. It could hardly be seriously maintained, for instance, that the Archbishop of Canterbury contemplates being whirled up into the firmament in this drastic fashion. Imagination staggers at the thought, and yet these words were probably written by one whose authority in the primitive Church was at least equal to that of the Archbishop of Canterbury in one which fondly believes itself to be the custodian of the same faith, - "the faith once for all delivered to the saints," as, following New Testament language, it is often called. It ought to be obvious to men of common sense that, whatever be the merits or demerits of modern orthodox Christianity, it is not the faith once for all delivered to the saints. All through the New Testament this belief in the near advent of the great change which was to put everything right is plainly expressed. Thus - 
"But this I say, brethren, the time is short. It remaineth that both they that have wives be as though they had none; and they that weep as though they wept not; and they that rejoice as though they rejoiced not; and they that buy as though they possessed not; and they that use this world as not abusing it; for the fashion of this world passeth away', (I Cor. vii. 29-3I).

In giving advice of this kind the writer is evidently firmly possessed by the conviction that the great change is so near that it would be better for serious-minded people not to get married and not to make any far-reaching plans for the future. One wonders what would happen if this kind of advice were being given from Christian pulpits to-day. The expectation out of which it arose must have been very strong, so strong as to be characteristic of the Christianity of the time, but, practically speaking, it no longer exists. The same expectation is alluded to in the gospels themselves, and the words are there put into the mouth of Jesus -

"When they persecute you in this city, flee into the next: for verily I say unto you ye shall not have gone through the cities of Israel until the Son of man be come" (Matt. x. 23).

"Let your loins be girded about, and your lamps burning; and be ye yourselves like unto men looking for their lord. . . . Be ye also ready; for in an hour that ye think not the Son of man cometh" (Luke xii. 35, 40).

This expectation, too, forms the whole background of the strange book called Revelation, the general theme of which is the absolute over- 
throw of the world-powers and the triumphant inauguration of the Kingdom of God. After a figurative description of the various catastrophes which are to precede this consummation, the writer tells, in language of unsurpassed beauty and pathos, of the incoming of heaven to earth -

"And I saw the holy city, New Jerusalem, coming down out of heaven from God, made ready as a bride adorned for her husband. And I heard a great voice out of the throne saying, Behold, the tabernacle of God is with men, and $\mathrm{He}$ shall dwell with them, and they shall be His peoples, and God Himself shall be with them and be their God; and He shall wipe away every tear from their eyes; and death shall be no more; neither shall there be mourning, nor crying, nor pain any more: the first things are passed away. And $\mathrm{He}$ that sitteth on the throne said, Behold, I make all things new" (Rev. xxi. 2-5).

Then follows an elaborate and well-sustained description of the character and proportions of this new city of God on earth, which most people seem to imagine to be an anticipation of the glories of some other world in the regions beyond death. It should be clearly recognized, however, that the ideal which gives such power to the pen of this unknown writer is precisely that of Rousseau and Mazzini with, perhaps, a more intense personal piety and mystical temperament associated therewith. His final outlook is cosmopolitan, too, though it starts from the Judaistic standpoint -

"And the nations shall walk amidst the light thereof: and the kings of the earth do bring their glory into it" (v. 24). 
He concludes his picture of the future with the words -

"The Lord, the God of the spirits of the prophets, sent His messenger to show unto His servants the things which must shortly come to pass. And behold, I come quickly" (xxii. 6, 7).

Before the theology, the outlines of which we have been tracing, had obtained such a strong footing in primitive Christianity considerable changes must have taken place. The Galilean peasants who first preached the Messiahship of Jesus were no theologians: all they had to proclaim was that Jesus was coming again soon, as all the Jewish world expected the national deliverer to do, and that those who prepared for His advent by amending their ways and taking the side of God against Satan would be admitted to the new kingdom and endowed with immortal life. They preached this good news with all their might, and cheerfully went to prison and to martyrdom as the price of their fidelity to it. How did it come about that they were able to do this and were so confident about the result? I can only conclude that they must have had some overwhelming evidence of the continued existence of Jesus, and that out of this evidence grew the theology of the resurrection, afterwards so elaborately developed in Pauline thought. We have seen that their whole general conception was such that they could imagine no resurrection which was not 
physical. They believed that when their Master came back from the under-world, the land of shadows, He must have re-entered the very body in which they had last seen Him, and taken that body with Him into the material heaven above the clouds. They believed $\mathrm{He}$ would come in the same manner as they had seen Him go. They had no conception whatever of a heaven beyond the tomb for ordinary mortals; their evangel necessitated the belief that a concomitant of the new order which was about to be established would be the endowment of all the followers of Jesus with a glorious immortality on the earth plane-a kind of perpetual youth. This was Christianity as it was first preached in Galilee and Jerusalem.

The change from nationalism to universalism. But there was one thing in which the first Christian preachers must have differed from the writers of the epistles. Nationalism had to be given up, and, as I have already said, it was not without a struggle that the first Christians were eventually persuaded to do this. It follows from what has been said in the preceding chapter that all their hopes were bound up with the restoration of the Jewish nationality and the removal of the foreign yoke. They had no other conception of the Kingdom of God. To them all other nations were "the kingdoms of this world," and their master was Satan. This is the notion alluded to in the 
story of the temptation to which Jesus was subjected when Satan tried to seduce Him from His vocation by promising to give Him " all the kingdoms of this world and the glory of them" if $\mathrm{He}$ would fall down and worship their over-lord; the scene fits in with the prevailing dualism to which we have already referred at some length. But before long the enthusiasm of the new faith burst its boundaries. According to the account given in the Acts of the Apostles it was Peter who first carried the evangel to people of nonJewish race, but the story lacks verisimilitude, and was probably inserted at a much later date in order to give Peter his proper traditional primacy in the evangelisation of the world. There is more foundation for the belief that the daring step was taken by the Paul who wrote Galatians, and it was not taken without considerable heartburning. Like the founders of the first French Republic, Paul wanted not merely an ideal nation, but an ideal world, and in His new-found enthusiasm he determined to carry the good news to the confines of civilisation. This was by no means an impossible thing to do, for civilisation was practically comprised within the limits of the Roman empire, which lay around the shores of the Mediterranean, and whose rulers were therefore fittingly called the "lords of the world." When Paul obtained the somewhat reluctant consent of the Christian society at 
Jerusalem to proclaim Jesus throughout the Roman empire, the permission may have been granted on the understanding that he should go first to the Jews of the Dispersion, whose synagogues were to be found in every great city. But wherever he went he was dogged by emissaries of the narrower national party at home, who maintained that before a foreigner could be admitted to the benefits of the coming Kingdom of God he must be naturalised as a Jew, that is, he must be circumcised and keep the law of Moses. Paul knew perfectly well that Greeks and Romans would never do anything of the sort in any large numbers, so he vehemently resisted the efforts of his opponents to divide the newly formed societies on such an issue. How fiercely the controversy raged we can only infer from the distant echoes which reach us through the pages of the fragmentary letters written at the time -

"But when Peter came to Antioch I resisted him to the face, because he stood condemned. For before that certain came from James, he did eat with the Gentiles; but when they came, he drew back and separated himself, fearing them that were of the circumcision" (Gal. ii. II, I2).

"With freedom did Christ set us free; stand fast, therefore, and be not entangled again in a yoke of bondage" (v. I).

"There can be neither Jew nor Greek, there can be neither bond nor free, there can be no male and female, for ye are all one in Christ Jesus" (iii. 28).

Paul's strenuous contention was that Jewish 
nationalism was too narrow a basis for the new order, and that its benefits ought to be extended to all who were included in the world-order which had absorbed Judæa itself. This was a most important departure, the effects of which can hardly be exaggerated. One can only speculate what modern civilisation might have been, but for the determination of this intrepid little Jew. Paul builded better than he knew, for if he had not succeeded in carrying his point Christianity would have perished in its cradle, as one of the already numerous Jewish cults whose horizon was bounded by the interests of their own people. A hint of the same controversy is given in Rev. iii. 9-

"Behold, I will make them of the synagogue of Satan, which say they are Jews, and are not, but do lie: behold, I will make them to come and worship before Thy feet, and to know that I have loved Thee."

Evidently feeling ran high in this time of new beginnings, but, happily for the world, the universalists gained the day as against the nationalists, and ere long the centre of gravity of the new movement was transferred from Jerusalem to Rome, and the Gentile converts outstripped the Jews both in numbers and enthusiasm.

The early Christian hymns. - It is this great transference which accounts for the adoption of 
Jewish Messianic expectation by the new communities everywhere. Thus among the earliest Christian hymns we find such compilations as the Magnificat, the song of Zacharias, and the song of Simeon. The use of these in modern worship has greatly weakened their force, for their original significance has been conventionalised away. It is rather ridiculous to hear a well-dressed congregation singing -

"He hath put down the mighty from their seats, and exalted them of low degree;

"He hath filled the hungry with good things, and the rich He hath sent empty away" (Luke i. 52, 53),

when we remember that the words were originally sung by groups of enthusiasts hiding from their persecutors in the catacombs of Rome, looking for a revolution in the affairs of this world, and meaning literally every word they said.

Similarly, it is somewhat impressive to remember that the hymn put into the mouth of the father of John the Baptist, but far more probably compiled from the language of Old Testament scripture by Jewish Christians, was a sort of Marseillaise with a religious flavour -

"Blessed be the Lord God of Israel, for He hath visited and redeemed His people, and hath raised up an horn of salvation for us in the house of His servant David (as He spake by the mouth of His holy prophets which have been 
since the world began), that we should be saved from our enemies, and from the hand of all that hate us; to perform the mercy promised to our fathers" (Luke i. 68-72).

The song of Simeon is an adaptation of the same sentiments to the new conditions under which foreigners became admitted to the fellowship of the Christian societies -

"Mine eyes have seen Thy salvation, which Thou hast prepared before the face of all peoples, a light for revelation to the Gentiles, and the glory of Thy peuple Israel" (Luke ii. $30-32)$.

The same set of changing conditions is doubtless alluded to in the brief account of the postresurrection appearances of Jesus given in the first chapter of the Acts of the Apostles -

"To whom (the Apostles) He also showed Himself alive after His passion by many proofs, appearing unto them by the space of forty days, and speaking the things concerning the Kingdom of God. . . . They therefore, when they were come together, asked Him, saying, Lord, dost Thou at this time restore the kingdom to Israel? And He said unto them, It is not for you to know times or seasons which the Father hath set within His own authority" (Acts i. 3, 5).

This passage evidently belongs to the period when the new religion had become fairly wide-spread, and the keenness of expectation concerning the speedy coming of the kingdom had worn off. It is a remarkable tribute to the moral enthusiasm generated by the new faith that it was able to survive the indefinite postponement of the hopes excited both by Jesus Himself and 
those who preached His resurrection and second advent. The promised kingdom did not come, although gradually but surely the night settled down upon the Roman empire and the ancient civilisation of which it had been the custodian and embodiment.

Communism of the Jerusalem Church.-One more point remains to be noticed before we quit this phase of our subject - the communism of the Apostolic Church. A great deal has been said about this experiment from time to time, but perhaps too much has been made of it. It is quite improper to appeal to it as a model for modern imitation. We are told that -

"All that believed were together, and had all things common; and they sold their possessions and goods, and parted them to all, according as any man had need" (Acts ii. 44, 45).

Evidently under the tension of the beautiful and unselfish enthusiasm which had been generated by the name of Jesus and the hope of the good time coming, these simple folk were prepared to do anything. But there was no economic theory behind their action. They neither approved nor condemned private property; what moved them was simply and solely their new sense of comradeship and their joyful anticipation of the coming time of peace and plenty. They thought there was no need to make plans; all they had to do was to hold together and witness their Master to the world 
until He came amongst them once more at the head of the hosts of heaven to deliver them from all their disabilities. Then, too, it should not be overlooked that these people were very poor, for, like most great movements, Christianity began among the lower orders. These Jerusalem Christians seem indeed to have been in straits, for occasional references are made to the collections which were taken on their behalf among the Gentile Christians of Asia Minor. (Perhaps this facilitated somewhat the task of the great man who first insisted on carrying the gospel to the Gentiles. It is, at any rate, significant that it is Paul's name which is mentioned in connection with these contributions.) There is no evidence that the communistic experiment was tried in the Gentile churches. On the contrary, there are not a few references to incidents which indicate that the Christian leaders abstained from active interference with existing institutions, even that of chattel slavery. The Epistle to Philemon is perhaps the best example of this general attitude. Here the runaway slave Onesimus is restored to his Christian master, with the injunction that he is to be treated "no longer as a bond servant, but more than a bond servant, a brother beloved" (v. I6).

Christianity and the Empire. - On the still more urgent question of the relation of the Christians to existing political authorities the policy adopted 
appears to have been that of non-resistance, and there is no respect in which the new faith was more sharply differentiated from ordinary Judaism. Jewish nationalist expectations culminated in the hopeless rising against the Roman power which was followed by the destruction of Jerusalem and the final removal of all the external signs of corporate national life. This disastrous event served to put an end to Jewish Messianic hopes for the time being, if not for ever, but it made no difference to the Christians, for their evangel was not now bound up with the hope of a re-establishment of Jewish nationality, but with the regeneration of human society as a whole. But we must not be deceived into imagining that the transplantation of the new religion from Jewish to Gentile soil meant an immediate abandonment of its political and social implications; the Roman Emperors knew better. From our present-day point of view it may seem remarkable that a wise and enlightened ruler, like Marcus Aurelius, for example, whose own ethical standard bore such a resemblance to that of Jesus should have rigorously persecuted the followers of Jesus. But there is nothing remarkable about it when we realise that the victory of Christianity implied the overthrow of the Roman Empire and the establishment of an entirely new order with Jesus as its visible head. Rome could afford to be tolerant, as she was tolerant, of other faiths, but not of this. The rapid spread of Chris- 
tianity meant the spread of opinions which, not without reason, were deemed equivalent to the subversion of constituted authority. The lower orders began to look to the fulfilment of the Christian ideal as their one hope of deliverance from their masters. Rome under the Antonines, as Gibbon has shown, had reached the highest point of external splendour and prosperity, but it was a greatness founded on a vast underlying discontent. Dr. Dill, in what is now the standard work on this same period, shows that with the increase of military rule the sufferings of the toilers become proportionately greater. Christianity came as a message of emancipation, and while its nascent enthusiasm lasted there was every prospect that Roman imperialism would have to set its house in order. There is nothing more dangerous to privilege and tyranny than a social gospel allied to religious fervour. Had the world been really ready for the Christian ideal of the Kingdom of God the fall of imperialism would have been synchronous with the rise of a world State in which the dream of present-day Socialism would have received fulfilment. But it was not to be. Christianity was conquered by becoming respectable. It did indeed mount the throne of the Cæsars, but only to replace secular by ecclesiastical tyranny. The present Church of Rome is but the shadow of the old Empire; it is the Empire perpetuated under ecclesiastical forms. It is one 
of the great contradictions of history that the religion which started as the promise of universal brotherhood should have come to be the chief bulwark of authority and the foe of liberty. The transition was perfectly simple. All that had to be done was to transfer the expectation of communal happiness from this world to the next, and the thing was done. Henceforth the advice to the poor and oppressed would be that they should remain passive under existing injustice, in order that they might receive compensation in heaven. A greater travesty of the original meaning and purpose of the religion of Jesus could not well be imagined.

Summary. - To sum up. We have now seen that the first followers of Jesus were Jewish nationalists, whose moral passion and social aspirations were more intense than those of their countrymen. They had somehow become convinced that their Master was still alive and would presently return to earth to complete the work $\mathrm{He}$ had begun, and they believed it to be their duty to publish this good news to the descendants of Abraham. But this simple ideal soon began to be mixed up with a theology derived from contemporary GræcoJewish notions about the origin of evil, the first and second Adam, and such like. The root conception in this theology, especially as it became associated with the name of the Apostle Paul, was that the work of the Messiah when He returned 
to earth would be to break the spell which Satan had cast over the souls and bodies of men, that is, He was to "abolish death and bring life and immortality to light." After the kingdom of Satan had been destroyed and the Kingdom of God established, none of the subjects of Jesus would ever again have to suffer or die. And just as Jesus was supposed to have risen from the dead, so would all the righteous who had died before His second coming rise again in order to take their place in the ideal Commonwealth. Before long this expectation was extended to Gentiles as well as Jews, principally through the exertions of the Apostle Paul. Henceforth the anticipated Commonwealth was thought of as world wide and knowing no distinctions of race or nationality. Even the dominance of one sex over the other appears to have been thought of as having to go, for Paul says there was to be no question of male and female in the new order. But perhaps all that was meant was that there was to be no more marrying or bearing of children - a supposition which certainly alters the complexion of the statement. No economic theories were indulged in; all was religious enthusiasm. It was revolution by miracle, not by blood and barricades; although, according to the book of Revelation, there must have been some vivid picturing of the dramatic nature of the final struggle, the Armageddon, in which the forces of hell would be routed and 
those of heaven prevail. Hence, while the Christians were persecuted for identifying existing political powers with the kingdom of Satan and prophesying their overthrow, they did not attempt to hasten this consummation by violence. All they did was to call for recruits to the side of Jesus and await His arrival.

It thus becomes evident that the hopes of the Christians were not at all dependent upon the theology which gradually developed in connection with them, and which occupies so large a place in New Testament writings. The allimportant thing in primitive Christian preaching was its intense belief in the coming of an ideal social order in which men would no longer feel any desire to strive against or injure one another. The superstitions about the dramatic second coming, the general resurrection, and the catastrophic nature of the changes which would then take place need not deceive us in the least. The worst of it is that these over-beliefs have become substituted in the course of time for the original Christianity; the non-essential has crushed out the essential; other-worldism has gradually replaced the glad tidings of the Kingdom of God with which Jesus began His mission to the world. 


\section{CHAPTER V}

\section{THE KINGDOM OF GOD}

\section{In Present-Day Christianity}

So far we have, I hope, succeeded in obtaining a fairly accurate general view of the situation out of which Christianity arose, together with the ideal implied in the new evangel. We have now to see how far Christianity as we know it to-day corresponds to this picture. In making our inquiry we have perforce to overleap the intervening centuries, and ignore vast and interesting developments which have had immense value and significance in the shaping of the complex civilisation with which we of the western world are familiar. But there is no help for it; we have to narrow our field of observation if we would lay bare the main issue which we propose to examine.

Individualist salvation. - The first thing, then, which strikes an impartial observer in reference to the question thus raised is the fact that modern Christianity has shed some of the illusions of apostolic teaching and substituted others. The next thing is that what was primary in Christian preach- 
ing has now become secondary; we are preaching the winning of the world for Christ, as we call it, but we place in the foreground the offer of an individual salvation which is to take effect in some other world than this, to reach which the Christian must first pass through the change called death. Now, this is so absolutely different from what the first followers of Jesus believed and taught that it is only by a long stretch of the imagination that present-day orthodox Christianity can fairly be regarded as Christianity at all. It would be easy to trace one by one how these changes in emphasis came about, but we must leave that phase of the subject alone and concentrate upon the task of showing what they are.

To begin with, then, we note that modern Christianity preaches an individualist salvation obtainable by believing something. Not only is this a drastic departure from the standpoint of Jesus, but it implies a point of view to which He was strongly opposed in the orthodoxy of His race and time. The issue declared in the sharp antagonism between Him and the Pharisees is one with which we are being confronted to-day, although we may not see it so clearly in our own case. It is truly astonishing to reflect that in these days the very thing against which Jesus strove so earnestly should have become entrenched in His own Church and be speaking in His name. It is somewhat startling to see how closely the conditions against which $\mathrm{He}$ vainly 
strove correspond with those which prevail in Christendom at this moment. The reason why Jesus condemned the ideals of the Pharisees was not that they knew themselves to be wrong and were determined to throw dust in the eyes of the public, but because their whole idea of righteousness was based upon a false conception. It is always easier to fight an out and out scoundrel, who knows he is a scoundrel and means to keep on being one, than to resist and overcome a man who claims the sanction of the highest for something that is unreal and harmful. In the former case the issue is clear and unmistakable; in the latter it is not. This was just how Jesus was placed with regard to the Pharisees. These claimed to be the custodians of true religion, and they looked down upon all who were less earnest and thorough than themselves in their adherence to the traditional forms of religion. They were the Nonconformists of the hour in contrast to the State Churchmen, the aristocratic priestly order. They were opposed to the Sadducees - and not without reason - because they held that these were worldlyminded. They glorified the past of the party to which they themselves belonged, and were always insisting that this party had been the one hope of Israel ever since the great struggle for the maintenance of national religion against Antiochus Epiphanes and the Syro-Greek dominion in the second century B.C. At that time the Hellenising party among the priests had been quite willing to 
accommodate the national faith to Greek forms; but the predecessors of the Pharisees prevented them from doing so, and held all the more tenaciously to the purely Jewish tradition. The Pharisees of Jesus' day prided themselves on this, and came to identify religion and righteousness with the rigid observance of the so-called law of Moses. They held that to be properly religious a man must obey the law, precept by precept, and if he succeeded in doing this he was righteous. The original reason for the existence of such precepts did not trouble them. They did not ask themselves why it should be accounted righteous to perform certain ablutions and to fast at certain periods. They just did these things because they were written in the law, and the whole fabric of observance was a matter of external authority. The vicious root of the system was its individualism, the assumption that a man could become righteous by doing certain things apart from all question of their bearing upon the well-being of his fellow-men. This was where Jesus came into conflict with them. He denied that there could be such a thing as an individualist righteousness, a righteousness entirely between man and God, and not between man and man. The Pharisees maintained that a man's merit in the sight of God had no direct relation to his dealings with his fellows, although, of course, it might be counted desirable to behave properly to other people. Jesus viewed this principle with detestation, and pointed out that 
the law itself, in its original significance, implied justice and kindness as between man and man. "Go ye and learn what that meaneth, I desire mercy and not sacrifice" (Matt. ix. I3). The rigidly pious folk could not understand this; it sounded like blasphemy. They had been so accustomed to think of the law as inviolably sacred that they were horror-stricken at any attempt to tamper with its provisions or inquire into its worth to humanity. In fact, they talked about the law precisely as orthodox Christians talk about the Bible now. To them it was God's Word, and therefore to be obeyed without cavil and without inquiring into the reason for obedience. Jesus contended that the whole Pharisaic system was thus radically wrong because it divorced righteousness from right doing as between man and man. He held that the true service of God was the service of man, and that the kind of righteousness which left communal obligation out of count was no righteousness at all.

It might seem at first sight as though the issue thus declared so plainly between Jesus and the official representatives of respectable religion in His day were non-existent now, but if we think so we shall be greatly mistaken. Precisely the same issue does exist, and parties are ranging themselves in much the same way with much the same result. And just as, for the moment, Jesus was defeated, or seemed to be defeated, by the forces of traditionalism, so is spiritual religion being choked 
to-day by ecclesiasticism in its various forms. What is there in common between the simple ethics of Jesus and the complex confessions of faith which now form the basis of Christian fellowship? Their very fundamental assumption is wrong, namely, the assumption that there is such a thing as an individualist salvation, and that it is vitally necessary to believe certain propositions in order to participate in the benefits of the gospel message. This, as we see, was the very thing against which Jesus protested so earnestly in face of the orthodoxy of His time, although the form it takes is somewhat different now from what it was then. The curse of modern religion, and especially of ordinary Protestantism, is this assumption that there is such a thing as an individualist salvation, whose principal benefits accrue in the next world, like an insurance policy with tontine profits. There cannot be such a thing as an individualist salvation any more than an individualist righteousness. No man is saved until he is willing to be lost in the service of his kind, and there is no salvation worth talking about which does not imply becoming a saviour. Believing unprovable propositions has nothing to do with the religion of Jesus. The only things upon which $\mathrm{He}$ insisted were those which were self-evident to the man whose judgment was not already warped by associating religion with some elaborate system based on external authority. The conventional religion of His day commanded the doing of formal deeds; the 
conventional religion of our day commands the acceptance of formal creeds; and at the basis of both is this vicious individualism which asserts a righteousness in the sight of God apart from all question of one's value to the world. There could be nothing more dangerous or a greater hindrance to true religion than this. It was the thing above all others which Jesus loathed, and for opposing which $\mathrm{He}$ was murdered in the end. Like the Pharisees, many of us are taking for granted to-day that our duty to our fellow-men is a sort of addendum to the Gospel rather than the very pith and marrow of it. When we talk about being saved, what do we mean? We usually mean that we have made sure of our individualist heaven. When we talk about trusting in the redeeming work of Christ, what do we mean? We mean - or are supposed to mean - that we are accepted of God on quite other grounds than that of our conduct to our fellows. When we talk about the imputed righteousness of the Redeemer, what do we mean? We mean that we are legally clear of transgression, no matter what our deserts may have been. In all this there is no indication that our only real individual merit consists in our value to the common life and our contribution to the common good. And yet this was the very thing upon which, as we have seen, Jesus insisted most strenuously. None of these theological fictions had any place in His teaching, and the assumption upon which they are 
all based $\mathrm{He}$ regarded with the utmost abhorrence. All our body of dogma is so much useless lumber, and even worse, for it re-erects the false standard of Pharisaic religion. It is not Christianity; it has nothing to do with Christianity; and to insist upon it is to miss the very meaning of Christianity.

Misleading doctrine of sin. - Closely akin to this offer of an individualist salvation is the false emphasis on sin. Once again we may illustrate the difference between the point of view of Jesus and that of modern orthodox Christianity by a reference to His controversy with the Pharisees. Jesus said very little about sin; the Pharisees scarcely talked of anything else. The difference in emphasis is unmistakable. So far as we can gather from the Gospel accounts, Jesus never exhibited any personal sense of sin, and this was just what made the Pharisees distrust Him; orthodox Christianity would distrust Him to-day for the same reason. The sinlessness of Jesus has now become a dogma, but it would never have occurred to Jesus to raise the question as to whether $\mathrm{He}$ were sinless or not. The artificial way of looking at things implied in such a question was utterly foreign to His nature. His thoughts did not appear to dwell to any great extent on the subject of sin at all, and the strictly religious people of His day expected from Him an amount of contrition which $\mathrm{He}$ did not show. The absence of this demeanour in a religious teacher not 
only puzzled them, but filled them with horror. The nearest approach He ever made to what looked like a consciousness of imperfection was in the question: "Why callest thou me good? None is good save one, that is God." He never said anything which indicated a feeling of personal unworthiness, and yet His mood was as far as possible removed from that of spiritual pride. On the other hand, the very self-consciousness of the Pharisaic type of piety made spiritual pride inevitable. Modern organised Christianity has fallen into precisely the same error for precisely the same reason, namely, its assumption that $\sin$ is a matter wholly between the soul and God, a corruption of human nature which pollutes us in the sight of the all-Father, no matter what our relations to our fellow-men may be. This is false and wrong; and it is all the more mischievous because it is difficult to assail it without seeming to lay too little stress upon the reality of wrong-doing. And yet, unless we do make clear the falsity of this view, we shall never secure that individual sensitiveness to social obligation which is the crying need of the hour. The fact is that, to a large extent, it is not Jesus, but the Pharisee that has won after all in the history of official Christianity. It is the Pharisee who has drafted most of our creeds, our liturgies, our public confessions of guilt and wickedness. The note of Jesus is hardly ever sounded in the ordinary public worship of the churches of to-day, and until we get it back the really essential thing in the work 
of Jesus will remain undone. Nearly all the language in which we have been trained "humbly to acknowledge and confess our sins before God" is unreal and untrue, and it would be better never to use it. It represents a morbid and unhealthy development in the experience of mankind. The assumption behind it is that somehow we are by nature foul and corrupt, do what we will, and that in the sight of God we must necessarily stand condemned like prisoners at a judgment bar. So terrible is our state that no language can adequately describe it. We have no merits, no righteousness, no worth of our own; were it not for the pardoning mercy and redeeming love of God we should be blotted out of His book of remembrance, as we richly deserve to be, and as we would have been but for Jesus. The whole meaning and purpose of the coming of Jesus were to save us from the eternal loss which is the natural consequence of this awful thing called sin. Everything that pietism could do has been done to magnify the grace and condescension of God in providing such a means of salvation for us, and our religious vocabulary has been ransacked to find epithets sufficiently severe and contemptuous wherewith to describe human nature. Christian congregations will stand and sing with the utmost complacency such effusions as the following, which can easily be paralleled from any authorised hymn book used in the public devotion of our churches:- 
"Oppressed with sin and woe,

A burdened heart I bear;

Opposed by many a mighty foe,

But I will not despair,

"With this polluted heart

I dare to comc to Thee, -

Holy and mighty as Thou art, -

For Thou wilt pardon me.

* * * * * *

"And wilt Thou pardon, Lord,

A sinner such as I?

Although Thy book his crimes record

Of such a crimson dye?

"So deep are they engraved, -

So terrible their fear,

The righteous scarcely shall be saved,

And where shall I appear?"

As a rule the respectable penitents who publicly describe themselves in this fashion are able to do so without the least perturbation. This represents what they have been trained to think about themselves in relation to God, and what preachers are still being trained in theological colleges to tell future congregations in the name of Jesus. Some time ago when addressing a meeting of ministers I described sin as selfishness. A subsequent speaker took exception to this definition as inadequate, and in a tone of deep feeling which marked his sincerity at the moment, but which a cynical outsider would have called cant, said to the assembly: "Is it noth- 
ing more than that to us, brethren?" He was met by an answering groan of assent.

Evidently the vast majority of those present agreed with the speaker's acknowledgment of his own innate depravity as well as theirs. ( $\mathrm{He}$ is, in reality, a most estimable man.) And yet at the bottom of their hearts every one of them must have known that he never had been guilty of anything worse than selfishness, and that his real culpability, his real turpitude, was to be measured by the amount of harm he had done to his fellow-men, and not by some purely fanciful foulness before God. Every one of those ministers must know, if he will only face the facts, that in practice in ordinary everyday life we measure men's worth by the selfishness or generosity of their dealings with one another and by nothing else. There is no real and demonstrable sense in which our standing before God can be measured in any other way. The evil of this unreal kind of talk is that it conduces to self-complacency, although at first sight it seems to do the very opposite. It is individualistic. It withdraws attention from the thing that really matters, namely, a rigid and searching examination of our conduct in relation to human society as a whole. This artificial language about our supposed foulness before God is quite consistent with a great deal of hardness and arrogance and want of conscientiousness in the 
treatment of one's neighbour. Champions of orthodoxy are not unknown who are so terribly anxious that human sinfulness in the sight of God should be insisted on that they have quite forgotten the need for manifesting a spirit of comradeship or fair play in their ordinary relations with their fellows. Many a commercial magnate is able to curse himself in general terms on Sundays and in church for his abstract unworthiness in the presence of his Maker, but is not too particular as to the ways in which he obtains his dividends on the remaining six days of the week, or the lives he crushes in the process. The connection between doctrine and practice is not altogether negligible in this respect. Psychologically speaking, it is quite understandable that, if a man can only persuade himself that he has done the correct thing about getting right with God on account of his theoretical sins, there is no need to be in a hurry about squaring the account with man, for of course man is of much less importance than God! We have seen that there were people who honestly believed this in Jesus' day, and that they also believed themselves to be the seriousminded people of the age. They strongly disapproved of Jesus, and regarded Him as a blasphemer without any proper sense of sin. The reply of Jesus was: "Woe unto you, scribes and Pharisees, hypocrites!" No greater irony could 
well be imagined than that the modern representatives of this same religious type should have appropriated Jesus, and be engaged in belauding and defending Him.

Meaninglessness of abstract confessions of sin. For the truth is that the ordinary church-goer does not really mean what he says in church about sin. He thinks he does at the time, but the moment he turns back to his ordinary relations with his fellows he insists to the full upon the recognition of what he considers to be his true value to society. He has two standards, one for the altar and one for the market-place. He tells God how desperately wicked he is, but if any one else says the same thing about him he wants to know precisely what he means, and if the accuser is foolish enough to particularise, and cannot justify his charge, probably the Christian will bring an action against him for defamation of character. Then, too, we all know quite well that we cannot, as a rule, distinguish in business between the Christian who has had his theoretical sins forgiven for Jesus' sake, and the man of the world who, presumably, has not. In fact, it is conceivable that the latter may be the kinder and better friend of the two. If so, we say so, and, in all our dealings with the particular circle in which we move, we learn to estimate and speak of men by what we are able to see of their uprightness and kindness of heart. The plain and simple truth is that no man knows what 
he really means when he confesses his foulness in the sight of God. No intelligible answer could ever be given to the question, What do you mean by God's holiness and man's sinfulness? other than to say, God's holiness is love, and nothing but love; human sinfulness is human selfishness, and nothing else. It is absolutely nonsensical to talk either about a righteousness or a blameworthiness in the sight of God which has a purely individual significance. Righteousness implies right relations with human society, just as sin implies adding to the common ill or taking from the common good. No man can be either good or bad in and by himself alone; his goodness and badness have all the time a social background. No crime of his can do any harm to God otherwise than as an injury inflicted upon man. It is because official Christianity has so largely lost sight of this in the past that we have had saints fleeing to the desert in order to cultivate their souls apart from the world. And it is because official Christianity has no clear grasp of it in the present that it subordinates the service of the common weal to the supposed necessity of saving one's own soul from a purely imaginary danger. There can be no saving of the soul otherwise than by the laying down of life in a noble self-forgetfulness to take it again in a greater sense of solidarity and a brightening of the common lot of humankind. It is no use 
saying that the churches have not fallen into the error thus indicated. They have. Their attitude to the question of sin compels it.

It would cut at the root of all the misunderstanding which exists between the churches and the masses if the former could only revise their attitude on this one question, and in speaking of sin begin with man's duty to man instead of man's duty to God. This is not to deny man's duty to God, but to get at it in the right way. We have nothing to repent of except the evil we have actually wrought in the world by our selfish and short-sighted conduct. There is no mysterious process whereby we can be whitewashed in the sight of God if we are still going on doing cruel things, and showing a grasping, unscrupulous spirit in our relations with one another. The one great thing that we need to get rid of in present-day Christianity is this false notion that sin against God is, something different from sin against man, or that we can be individually justified before God, and made safe at some future judgment, without taking into account what is owing from us to a needy world. Instead of paying missioners to save "perishing souls" by inducing them to believe something or other, our duty is to begin with perishing bodies, and rescue them from the cruel maw of a system under which the very money with which we pay the missioner has been squeezed out of their 
life-blood. Slowly but surely, the sluggish conscience of the churches is being awakened to the unreality of the ordinary assumptions about sin. There is a passage in the "Biglow Papers" which exactly expresses the traditional view of this subject, and, by implication, exposes its hollowness -

"I'm willing a man should go tolerable strong Agin wrong in the abstract; for that kind o' wrong

Is ollers unpopular, and never gets pitied,

Because it's a wrong no one ever committed;

But you mustn't be hard on particular sins,

'Cause then you get kickin' some people's own shins."

Some one recently sent me a cutting from a newspaper containing an article by a clergyman's son, entitled "Sin and Selfishness." I regret that I cannot give the name of the newspaper, but the following extract from the article in question is well worth attention:-

"It is strange that a word associated with religion should so fail in its effect that when we want to appeal to a man, we have to appeal to some quality not specially associated with religion. Call a man wicked and you do not rouse him; you may even flatter him. But call him a coward, or say he is not a gentleman, and you have touched his conscience. So with sin and selfishness. It is no slur to call a person sinful; he will only xoply that we are all sinful, but that the grace of God will save us, and so forth. But call him selfish and you have touched a sore point and impugned his honour. Honour does not seem to be an ecclesiastical conception; it is a chivalric conception; wherein it seems as though the former had indeed failed of its true mission." 
But this same thing was said ages before by the Founder of Christianity Himself -

"If therefore thou art offering thy gift at the altar, and there rememberest that thy brother hath aught against thee, leave there thy gift before the altar, and go thy way, first be reconciled to thy brother, and then come and offer thy gift."

And even Jesus was quoting from the great preachers of ancient Israel in language with which His hearers were already familiar.

Vicarious atonement. - A third feature in modern Christianity, implied in both of the foregoing, is the accepted theory of the way in which sin is supposed to be atoned for and salvation made possible. It is true that modern preachers speak with halting tongue on this subject, because they have come to feel the difficulty of presenting a reasonable and coherent explanation of their theory. But underneath every partial explanation offered in an orthodox pulpit, Catholic or Protestant, is the outrageous assumption that Jesus of Nazareth, by His cruel death on Calvary, somehow purchased Divine forgiveness of sins for the whole human family, a forgiveness, however, which must be individually claimed. This monstrous assertion - for such it is - vitiates the whole of our religious life, and has done so for ages. The truth about the matter would be obvious enough but for the theological atmosphere which surrounds it. This mischievous fiction has acted in countless instances as a kind of 
anæsthetic to the moral instincts, and served to divert attention from the plain and obvious fact that such forgiveness never needed to be purchased, and that humanity is being crucified every day for the sins of organised society and the cruelties of individuals. By the invention of this doctrine, of which no one has ever yet succeeded in giving a sensible explanation, ecclesiasticism has transformed a wicked murder into a sort of bargain between God and man, the situation it was designed to meet being nothing more nor less than a figment of the religious imagination. The supposed wretched condition of the sinner in the presence of his sovereign Judge has no existence save in the fanciful soteriology of dogmatic Christianity; it is a needless misery inflicted upon the human mind which has already miseries enough. The time wasted in the discussion of this doctrine has represented a vast amount of energy withdrawn from the practical question of how to lessen the sum of human disabilities. It is as though we had been watching the semblance of a shipwreck in the clouds, oblivious of the fact that there was a real shipwreck on the rocks below.

Other worldism. - A fourth difference between present-day Christianity and the primitive faith out of which it arose is the transference of interest, in theory at least, from this world to the next. There could be no more conspicuous contrast between the Gospel preached by Jesus and His followers and 
the Gospel as now preached in His name than this. It is one mark of the limitations of the first Christians that they believed so intensely in the sudden transformation of human society; it is one mark of the limitations of their present-day successors that they believe in it so little. What we hear about now is the number who have availed themselves of the merits of Jesus and are on their way to heaven the general Protestant view; or the number who have joined His mystic body, the Church, for the same purpose - the Catholic view. That this otherworldism had no place in primitive Christianity never occurs to the ordinary church-goer to-day. That the primitive Christian view was a mistaken one goes without saying, but it was far worthier and far nearer to the truth than the one which in the course of history has been substituted for it.

The Church and the kingdom. - A fifth difference is that which relates to the meaning and function of the Church itself. In the light of the historical criticism of the Christian sources what a pitiful waste of a good man's opportunities is the Apologia of John Henry Newman, for example! Here was a man who started his life work with the assumption that his first duty was to save his soul from a future hell, and that to do so he must find and enter the true Church, the sphere of covenanted grace, the ark of salvation, founded by Jesus Christ for the rescue of a remnant from impending destruction. In the light of the same set of facts how meaning- 
less, too, is ordinary Protestant Church membership! For what originally was this Church of Christ but the company or society of those who were looking for their Master's second coming to put the world right, and who thought it their duty to keep on telling their neighbours that this consummation was near at hand? The centre of gravity has shifted enormously since the tiny groups in which primitive Christianity organised its growing life became welded into one compact whole with powerful officers and elaborate administrative machinery. The very word "Church" has undergone a transformation. Originally it meant no more than the company of those who were "called out," as the name signifies, to witness for their Lord in the kingdoms of the world which were shortly to be replaced by the Kingdom of God. Where now is this expectation of the Kingdom of God? It has been attenuated into insignificance in comparison with the importance of the Church which was originally only its herald. The Church and the Kingdom have even been persistently confounded, until to-day many a good orthodox Christian thinks they mean the same thing and sings devoutly -

"I love Thy kingdom, Lord, The house of Thine abode, The Church our blest Redeemer saved

With His own precious blood."

At another time, and from another point of view, he supposes the Kingdom to be identical with a 
heaven beyond the tomb. Occasionally he uses phraseology which implies that the Kingdom is inward and spiritual, the reign of God in the heart of man, and will never find outward expression. But an examination of the facts of the case would demonstrate beyond dispute that none of these represent the idea of the Kingdom with which Christianity started its career. That idea was a firm belief in the establishment of a perfect Commonwealth or universal brotherhood wholly of this world.

New Testament origins of modern. dogma. - It must be admitted that these misleading views as to the nature of the Christian evangel find some support in the New Testament, especially in the epistles. They have been greatly modified in transition, but, in principle at least, most of them are to be found there. But this need not disturb us, nor force us upon the dilemma of either abandoning Christianity altogether or accepting it in its present irrational and unsatisfying dogmatic form. There is no avoiding the issue. Ecclesiastical Christianity does not relate itself to the pressing needs of the age, and it is an insult to the intelligence. Must we give it up, or has it a message which we can recover? Assuredly it has, essentially the same message as that with which it began its history, the glad tidings of the Kingdom of God. We must examine at closer quarters presently what these glad tidings imply for the modern mind. But before we can succeed in 
getting a clear idea as to what the essential message of Christianity really is we must be frankly prepared to admit and reject the illusions both of the New Testament Christians and their successors of to-day. No modern preacher really presents the Christian evangel in its literal New Testament setting; he cannot do so. It is impossible to believe that death came into the world as the result of sin, and yet in the Pauline writings the assertion is emphatically made that it did. It is impossible to believe that the world as we now see it represents the ruin of what it once was, and yet this is the very startingpoint of the Pauline doctrine as to what salvation was for. The difference between ancient and modern Christian thought on these points is not unimportant; it is fundamental, and we are guilty of a want of intellectual honesty if we pretend to ignore it. Then again, it is impossible to hold, with Jesus and His apostles, that the world as it now is constitutes the kingdom of Satan, and that all the evil in it is due to Satan and his agents. It is impossible to believe that its deliverance will be effected by the catastrophic coming of a new order called the Kingdom of God, preceded by a colossal break-up of this kingdom of Satan. Nobody believes these things - least of all those guardians of probity and right thinking, the wealthy proprietors and editors of the orthodox religious press, who, one would think, could have little to gain by such a quickchange revolution in human affairs - and there is 
no sensible reason for going on assuming that we do. We know, too, that the New Testament Christians did not believe in dying and going to heaven, as we are supposed to do now, and they certainly did believe in a personal immortality on the earth plane, a thing not only incredible but even repugnant to the modern mind. How in the face of these facts are Christian preachers going to keep on telling their flocks that the Christian hope of immortality finds its justification in the New Testament and is precisely now what it was then? The emphasis has entirely changed since Christianity was first preached in the Roman empire, and the fashion in which it is presented now is utterly different from that in which it was presented then, although we manage to continue using the very words of those primitive preachers as though the difference were non-existent. No greater proof of the unreflective character of present-day Christian observance could be found than the fact that tens of thousands of people repeat in church every Sunday words which imply an outlook on life which no ordinary being in possession of his faculties ever dreams of taking now-a-days, and yet they do it all apparently without the least suspicion that the performance is meaningless and absurd. We cannot have much hope that the churches will come into line with reality in modern life until the illusions of early Christian preaching are fully recognised and admitted. That being done without hesitation and without reserve, we shall be 
able to get firm hold once more upon what has proved to be strong and permanent in the primitive Christian evangel.

The necessity for freeing Christianity from otherworldism. - But even before this is done we shall have to surrender our own illusions. We shall have to stop contradicting ourselves in our solemn professions of faith, and we shall have to disown the immoral implications of some of our favourite doctrines - doctrines which have not the shadow of foundation in the teaching of Jesus Himself. The whole fabric of our other-worldism will have to go. We may not doubt the continued selfconscious existence of the soul after death, but we must stop talking as though correctness of creed could make any difference to its eternal destiny. We must have done with the falsehood that believing something or other about the execution of Jesus on Calvary will act as the plutocrat's open sesame to glory, or that the lack of it will doom some poor ignorant child of the slums to hell. If we know that these things are revolting to the moral sense, why do we not say so? Why do we continue to hover around them, and use vague phrases which assume a belief in them we dare not attempt to justify? But they are written in the New Testament! I have already shown that it is not so, but what would it matter if they were? If orthodoxy has already set aside that part of the New Testament in which it cannot believe for scientific reasons, why 
does it hesitate about repudiating another part of it for moral reasons? What Paul says Jesus died for is not what the modern preacher says He died for; the difference in their respective views on the supposed connection between sin and death is alone sufficient to explain the difference in emphasis. Let us, therefore, frankly admit that the otherworldism of commonplace Christianity to-day has no place whatever in the pages of the New Testament. Grant that the first Christians were wrong in supposing that the dead would come back here; granted they were limited in not seeing that a progressive personal immortality on the further side of death is better than any return to this mundane sphere, however triumphant - what then? It still remains true that they were stronger and clearer in their vision than we are, for they concentrated all their efforts on the endeavour to awaken men to the realisation that this world must become a Kingdom of God. That they thought God would do all the work is not to their discredit, for it is perfectly true. All noble human effort is the forth-putting of the universal life in higher and fuller self-manifestation. Cannot we catch the same spirit? Cannot we cease to pay attention to the other world, and concentrate upon the task of regenerating this one? Cannot we believe, with the same spiritual intensity as the first followers of Jesus, that this is the will of God for men, and that the Divine voice is ever summoning fresh labourers to the vineyard? 
Summary. - In order to bring the argument to a focus let us sum up once more. Modern orthodox Christianity, owing to the increase of human knowledge, has outgrown the illusions of primitive Christianity, but has adopted others in their place. It preaches an individualist salva-

2 tion, to take effect after death, and obtainable by - faith. It puts an entirely false emphasis on sin by representing it as a matter between man and God to be atoned for by the merits of a special Redeemer. The main emphasis in its evangel is laid upon the supposed necessity of preparing individuals for the world to come. This has led to a view of the function of the Church entirely different from that with which Christianity began. Some of these modern doctrines are rooted in the New Testament, but not to the extent that is commonly supposed. The whole emphasis is different, for primitive Christianity confined its interest to the establishment of the Kingdom of God in this world, whereas modern Christianity has weakened its efforts in this direction by its other-worldism. This will have to be given up, just as we have already given up the whole New Testament view as to the connection between sin and death, the structure of the universe, physical immortality, and the like. Then, and not till then, shall we be able to recover something of the intensity and enthusiasm which accompanied the early Christian preaching of the glad tidings of the Kingdom of God. 


\section{CHAPTER VI}

THE COMMON OBJECTIVE OF CHRISTIANITY AND SOCIALISM

The essential principle of Christianity. - It may appear to some, even among Christian Socialists, that our thorough-going analysis of Christian origins as contrasted with modern Christian doc. trines leaves very little to which the name Christian can properly apply. But this is an entire mistake, although a mistake which defenders of the nonessential are always making in relation to Christianity as well as other things. The object of our analysis has been to get down to bed rock and to show what was the real objective of the simple Galileans who first went forth to publish the message of Jesus to the world. If I am right in maintaining that the one all-dominating conception in their preaching was their firm belief in the advent of the Kingdom of God, surely we have gained something in realising that everything superimposed upon this has tended to weaken the force of the original evangel. Surely, too, it is better to recognise that the naïve beliefs of these early Christians in the miraculous nature of the coming of the new order have no value for us now, and that the wisest thing 
we can do is to accept their ideal without being limited by their superstitions. We cannot too strongly insist that the work of Christianity is to realise the Kingdom of God on earth and nothing else. Christianity has not, and never has had, any other Divine commission. Everything added to this has been a hindrance rather than a help; everything antagonistic to it is something quite different from Christianity, even though it may assume the name. The Kingdom of God as Jesus understood it could never have been anything less than a universal brotherhood, a social order in which every individual unit would find his highest happiness in being and doing the utmost for the whole. If this one plain and simple principle be kept clearly before our minds, we shall not need to be apprehensive that with the disappearance of supernaturalism (in the ordinary dogmatic acceptation of that word) Christianity has disappeared likewise. The exact contrary is the case. If we never lose sight of that objective, or mix it up with anything else, we shall be able to differentiate between what is truly Christian in modern developments and what is not. Anything that tends towards universal brotherhood is Christian; anything that makes for wider life for all instead of for the few only is Christian; anything that encourages the highest selfexpression of the individual in the service of the common good is Christian; anything that tends towards the destruction of selfishness and the demo- 
lition of all barriers of privilege between nation and nation or man and man is Christian.

Identical with Socialism. - Now what is this but Socialism? Socialism may be preached occasionally by avowed agnostics like the editor of the Clarion, or by convinced sacerdotalists like Father James Adderley, but in so far as their objective is what is here stated they are both Christian. Their Socialism is the practical expression of what always has been fundamental to Christianity, and the thing they are aiming at is precisely what all the primitive Christians hoped to live to see.

For what is Socialism? The answer to that question depends upon the point of view. One exponent may quite honestly pursue, or think he pursues, his ideal no farther than the purely material plane. If so, he will define Socialism as the communal ownership of the means of production, distribution, and exchange. Supposing him to be consistent in his materialism he may disavow any objective other than that of wringing from the niggardly hand of Nature as many creature comforts as possible. He may say that he does not care three straws about "bainting and boetry," as George the Second is reported to have contemptuously described culture in his characteristic German accent. He may even tell you that he does not love his neighbour as himself, and does not intend to do so, but that he has found it to be for their mutual interest to stop the waste which 
ensues when nations and individuals are competing with each other, and to take as full advantage as possible of the benefits which would accrue from a combination of resources. This would be quite legitimate ground to take, and our friend, as far as he goes, is a true Socialist. There may be many such Socialists for anything I know, but I can honestly say I have never met one of them. I have met several who have started their exposition of Socialism by a disclaimer of any higher aim than that of getting the most out of life in the way of leisure, comfort, and luxury; but as they have proceded, and warmed to their subject, I have usually found them vibrating with moral passion and appealing to the highest instincts of their hearers on the ground that human suffering calls for pity and remedy. As soon as I hear this note I am quite satisfied to let our militant materialist go on preaching Christianity in his own way. The truth is that the words "materialist" and "materialism" are very loosely used in our common speech. Your true materialist is the man who goes on consistently endeavouring to draw to himself as much as possible of the good things of life regardless of the effect of his action upon the common weal; and the name cannot properly be applied to any man whose heart is aflame with pity for his kind and a desire to help and heal, even though he may be unable to believe in a God or a future state. Materialism, in the strict sense, has often been allied to orthodoxy, 
and still exercises a not inconsiderable influence in the councils of official Christianity; materialism, theoretically construed, has often shown itself to possess more of the spirit of Christ than it cared to avow - in fact, materialism in this sense has usually been a reaction against the selfishness and insincerity of dogmatic religion. But let that pass. All I care to show at the moment is that the aims of Socialism, even from the material point of view, are distinctly Christian. They are Christian because they insist on the desirability of getting together instead of keeping apart, and on mutual helpfulness instead of mutual hindrance.

Moral ideal of Socialism. - But from the moral point of view the case is clearer, and should require no defence. From this standpoint Socialism may be defined thus: "All for each; each for all." It means from the individual the utmost for the whole; from the community it means the best for the weakest. It is the denial of the ape and tiger qualities and an appeal to the higher motives of justice, compassion, and public spirit. It is along this line that Socialism is making its most powerful appeal to-day and gaining the largest number of adherents. Will any one seriously affirm that this is something other than Christian, or, indeed, that it was not the very starting-point of the Christian appeal? "It is not the will of your Father which is in heaven that one of these little ones should perish." "He that loveth his life shall lose it, 
and he that loseth his life shall find it." "Love is the fulfilling of the law." This it is which is lending to Socialism the fervour of a new religion, and yet it is only the religion of Jesus making its appeal to modern needs with its original end in view. If it were concerned only with the meat that perisheth it would not arouse the enthusiasm it is proving itself able to do in the minds and hearts of the rising generation. Its power is due to the fact that it promises opportunity for the release of higher energies and nobler motives than can find free play amid the hampering conditions of modern industrialism. It sees clearly that before refinement and culture are possible, not to speak of nobleness of thought and aim, the foundations of physical efficiency must be laid strong and deep. To talk as though the higher life were possible to a denizen of the slums who is never free from anxiety for daily bread, it stigmatises as sheer hypocrisy, or folly, or both. The Christianity that contents itself with inculcating kindness while upholding private property in the means of livelihood it declares to be no blessing but a curse. Men must eat and drink and be provided with clothing and shelter if they are to be free to rise above mere animalism and to think great and beautiful thoughts. It is all very well for the Christian to be taught to show sympathy with those in sorrow, to wipe all tears away, and to bind up the broken-hearted; but what is urgently needed is that he should learn to 
attack the root causes of sorrow and tears and broken hearts, which is precisely what the average Christian seldom thinks of doing. We content ourselves with more or less spasmodic attempts to rescue the flotsam and jetsam of our present cruel social system, without realising as we should that the Kingdom of God is impossible until the forces are destroyed which make such wreckage inevitable.

Some misapprehensions concerning Socialism. Few would quarrel with Socialism if it were understood to mean no more than that every man should be free to be and give his best to the community without hurting or impoverishing any one else. But this, many would say, is just what Socialism would render impossible, for it would mean the creation of a cast-iron economic system in which true individuality would be crushed. This is a curious argument to bring forward in face of the achievements of individualism in the past or even in the present, but it is quite honestly made by people who would become Socialists to-morrow if they could only be sure that their fears in this respect were groundless. It may seem a paradoxical thing to say that the most conspicuous fruit of unrestrained individualism has been the crushing of individuality and that the thing most to be hoped for from Socialism will be the development of individuality, but so it is. This is an assertion the truth of which I have now to demonstrate if I can. Then, again, there are many people, utterly disgusted and weary 
with our present social system, who would gladly welcome Socialism if only they could be convinced that it is practicable, but they do not believe it is. They will assert that human nature has to be reckoned with, and that human nature, being largely selfish, would mar the most ideal system ever invented. To these objections we may add others derived from an entire misapprehension of the practical proposals of Socialism. We are told that Socialism stands for free love (as it is euphemistically called) and the break-up of family life; that it means spoliation and confiscation; the destruction of all trustworthy incentive to industry; the maintenance of the idle and vicious at the expense of the thrifty and sober. If I can succeed in showing not only that these charges are unfounded, but are the very opposite of the truth, it may do a little to clear away the mists of prejudice from the minds of some who still cling to the belief that a change from our present unideal condition of things to anything in the shape of Socialism would be out of the fryingpan into the fire. I desire to take the highest ground possible in my appeal to the motive for effecting the change, but at the same time I shall willingly stand condemned if $I$ fail to prove that the change is thoroughly reasonable and practicable. People, even prelates, have pointed out that the Sermon on the Mount is impracticable and should be understood as a counsel of perfection merely. Well, so it is in such a society as ours to-day. I will defy any man 
to live by the principles of the Sermon on the Mount without coming to grief so long as our present system is tolerated. What we want is a system wherein it could and would be practised without loss and ruin to those we love most. When we get that system we shall have the practical realisation of the Christian ideal in so far as it can ever find outward expression in this world. It will thus be seen that the task I am now attempting is no trivial one, and that it will require clear and definite statement before the average hard-headed man of affairs will consent to take the point of view advocated in these pages. I propose, therefore, to examine briefly the situation for which Socialism professes to be able to find a remedy. I will then suggest the remedy and show how it might be put in operation. In the discussion of the problem we shall have to face some of the more serious objections indicated above and show what Socialist policy really is in regard to them.

The present situation outlined. - In a tract entitled "Facts for Socialists," published by the Fabian Society in 1906, are some interesting statistics in a fairly small compass. Let me urge the reader not to skip these figures, for they are most illuminating. I willingly concede that statistics are often misleading, and that at the best they never can be an adequate substitute for first-hand acquaintance with every phase of the subject to which they relate; but in this instance the figures serve 
to focus a case which could easily be established without them; they are simply the unemotional symbols of misery. Whether they are absolutely exact or not is not a matter of great importance; their value consists in the fact that they are an irrefutable general statement of the way in which rather more than forty millions of people manage to live together in the British Islands to-day.

(I) The nation's annual income, roughly estimated, is not less than $\$ 9, \infty 00,000,000$. This amounts to about $\$ 870$ per adult man, probably rather more.

(2) How are the commodities represented by this vast sum produced? They are produced solely by the efforts and sacrifices of the working portion of the community employed upon the gifts of $\mathrm{Na}$ ture. Labour is the only source of wealth. The idle rich and the idle poor are therefore equally pensioners upon the bounty of the labour of others.

(3) Who are these workers? According to the census of IgOI there are nearly thirteen million males and five and a half million females, or a total of eighteen million workers employed in industrial, agricultural, commercial, domestic, and professional occupations. Over thirteen and a half millions of people under twenty years of age are unoccupied, and nine and a half millions over twenty. Of these last, however, over eight and a half millions are women, most of whom may be engaged in domestic work. But on the other hand we have to allow 
something for the numbers of people whose work is merely nominal. Nevertheless there were in this census year 663,656 adult men (that is, one in every twenty) who did not profess to have any occupation whatever. Most of these belonged to the class of the idle rich.

(4) How do the idle rich live? Principally, of course, upon what is called rent and interest, that is, by the fruits of the labour and abstinence of others, for which they return no equivalent. Their supposed right to do this is legally guaranteed to them by the tacit consent of the whole community.

(5) What is rent? Rent is the price paid for permission to occupy and use lands, houses, mines, quarries, iron-works, gas-works, water-works, canals, fishings, shootings, markets, highways, and suchlike. The total rent of the United Kingdom must amount to at least $\$ I, 450,000,000$, or nearly one-sixth of the total annual income. It is probably now very much more.

(6) What is interest? Interest is the price paid for permission to use capital, and capital is that portion of the national wealth which is used in producing more wealth. Strictly speaking, the physical and mental efficiency of the workers themselves is capital, but we do not commonly reckon that way - it would be better if we did. It is difficult, too, to distinguish between wealth consumed and wealth directly employed in production. But, roughly speaking, the total amount received annually as interest, over and 
above the amount consumed by the workers in the process of production, is not less than $\$ \mathrm{I}, 800,000,000$. We thus get a total of $\$ 3,250,000,000$ annually for rent and interest together out of the total income stated above.

(7) Where does this part of the national wealth (rent and interest) go to? It does not all go to the idle rich. A great part of it goes in what are called "wages of superintendence," or " rent of ability." This class may be held to include not only those employers of labour who directly superintend their own business, but the whole of the literary, artistic, and governing classes of the community - in fact all who do not belong to the manual-labour class. Of course, even a preacher or a Prime Minister has to be fed, clothed, and housed, although he does not spin or dig; he therefore lives upon the spinning and digging of other people, although it is to be hoped that the kind of serivce he renders is worth something in return, even if it cannot be measured in material units. But this whole class, which includes all grades, from a clerk at a few dollars a week to the Archbishop of Canterbury with seventyfive thousand a year, takes from the total annual product about $\$ 2,300,000,000$ in profits and salaries.

(8) The Classes and the Masses. If we include in the former designation all those who are permitted to draw and dispose of "the three rents" (land, capital, and ability), their share of the total annual income amounts to about $\$ 5,550,000,000$ - 
that is, to nearly two-thirds of the whole. If we include in the masses all who belong to the manuallabour classes, the amount allocated to them can only be about $\$ 3,450,000,000$ - that is, rather more than a third of the whole.

(9) Comparative Numbers of Classes and Masses. About one-seventieth part of the population of the United Kingdom owns far more than one-half of the entire accumulated wealth, public and private. The landlords of more than ten acres number only I76,520, and own ten-elevenths of the total area; more than one-half is owned by 2500 people. More than one-third of the entire income of the United Kingdom is enjoyed by less than one-thirtieth of its people. The incomes of $\$ 800$ per annum and upwards are only one million in number. Nearly onehalf of the entire income of the United Kingdom is enjoyed by but one-ninth of its population. The number of persons employed at wages in the industries of the United Kingdom is placed at thirteen to fourteen millions, and this includes over four million women. Nine hundred and thirty-nine out of every thousand persons (about half of whom are adults) die without property worth speaking of, and nine hundred and sixty-one out of every thousand without furniture, investments, or effects worth \$1500.

Some of these figures are taken from Mr. Chiozza Money's "Riches and Poverty," and others from Mr. Mulhall's "Dictionary of Statistics." 
(10) The Struggle to Live. The interests of the workers and of the small class which thus takes the lion's share of the produce of their labour are therefore of necessity essentially opposed. It is impossible for the workers to live the cultured life enjoyed by the privileged moiety of the nation; consequently, one secondary result of their poverty is that they are tempted to seek enjoyment in coarse and harmful ways. One secondary result of the idleness of the rich is temptation to the various forms of excess which luxury encourages when the mind is not occupied by any serious purpose.

"The force by which this conflict of interest is maintained, without the conscious contrivance of either party, is competition, diverted, like other forces, from its legitimate social use. The legal disposers of the great natural monopolies are able, by means of legally licensed competition, to exact the full amount of their economic rents; and the political economists tell us that so long as these natural monopolies are left practically unrestrained in private hands a thorough remedy is impossible." ("Facts for Socialists," p. I2.)

(II) Some Victims of the Struggle. Of the great permanent army of the " unemployed," no reliable statistics can be obtained. The average number of persons in London whose home is the "common lodging-house" is over 30,000 ; over I 100 are every night found in the casual wards. The classes on or below the poverty line of earnings not exceeding 
a guinea a week per family number $1,292,737$, or 30.7 per cent. of the whole population. To these must be added 99,830 inmates of workhouses, hospitals, prisons, industrial schools, etc., making altogether nearly $\mathrm{I}, 400,000$ persons in this one city alone whose condition even the most optimistic social student can hardly deem satisfactory. (These figures are taken from Mr. Charles Booth's monumental work, "Life and Labour of the People in London.") In England and Wales, in 1904, 90,776 deaths were registered as having taken place in workhouses, infirmaries, hospitals, and asylums, or I6.5I per cent. of the total deaths. Of these, 48,884 occurred in workhouses, $32, \mathrm{I} 4 \mathrm{I}$ in hospitals, and 975 $\mathrm{I}$ in lunatic asylums. In London, in I904, one person in every three died in the workhouse, hospital, or lunatic asylum. A large number of those compelled in their old age to resort to the workhouse have made ineffectual efforts at thrifty provision for their declining years. In I890-9r, out of $175,85^{2}$ inmates of workhouses (one-third being children, and another third women), no fewer than I 4,808 had been members of benefit societies. In 4593 cases the society had broken up, usually from insolvency. The number of persons who die while in receipt of out-door relief is not included in this category. Fifteen thousand seven hundred and twenty-seven persons died by fatal accidents in 1904: 98I losing their lives in mines, quarries, etc.; 804 on railways; 250 in working machinery; 520 
by poisoning and poisonous vapours; and 203 in building operations. These are the figures for England and Wales alone, and would be much increased by including the accidents in Scotland and Ireland. The Board of Trade report on railway accidents during the same year shows that $4 \mathrm{I} 6$ railway servants were killed and $392 \mathrm{I}$ injured by accidents on the lines.

Mr. B. S. Rowntree has estimated, in his wellknown work on "Poverty," that the average income from all sources of the 11,560 working-class families in York, in 1899 , was about $\$ 425$ a year. But 15.46 per cent. of the wage-earning class were living in "primary poverty," that is, on less than enough to provide the minimum of food, clothing, and shelter. Here I may insert a paragraph from Mr. Rowntree's book, in which the author states in a vivid and telling fashion something of what this involves -

"Let us clearly understand what 'merely physical efficiency' means. A family living upon the scale allowed for in this estimate must never spend a penny on railway fare or omnibus. They must never go into the country unless they walk. They must never purchase a halfpenny newspaper or spend a penny to buy a ticket for a popular concert. They must write no letters to absent children, for they cannot afford to pay the postage. They must never contribute anything to their church or chapel or give any help to a neighbour which costs them money. They cannot save, nor can they join a sick club or trade union, because they cannot pay the necessary subscriptions. The father must smoke no 
tobacco and must drink no beer. The mother must never buy any pretty clothes for herself or for her children. Should a child fall ill it must be attended by a parish doctor; should it die it must be buried by the parish. Finally, the wageearner must never be absent from his work for a single day. If any of these conditions are broken, the extra expenditure involved is met, and can only be met, by limiting the diet, or, in other words, by sacrificing physical efficiency."

"One great cause of the short and miserable lives of the poor is the insanitary condition of the slums in which many of them are compelled to dwell. The strongest testimony to the evil effects of such surroundings comes from the insurance companies. The industrial friendly societies have in each large town their 'proscribed streets.' The Liverpool Victoria Legal Friendly Society proscribes, for Liverpool alone, on account of their insanitary character, I67 streets ' wherein no members of the Society may be entered.' Yet these unhealthy streets are not too bad to be the only homes of thousands of the poorer citizens of that commercial centre." ("Facts for Socialists," p. I5.)

It is difficult to know what proportion of the wageearning class receives assistance from charity or seeks poor relief from the Guardians. There is among the poor a practically universal horror of the workhouse, and yet the number of paupers in actual receipt of public relief is more than a million daily. Mr. Charles Booth estimates the pauper class as about one in six of the manual workers. It costs 
about $\$ 80,000,000$ a year to maintain these paupers, not to speak of the enormous amount of private charity which is dispensed.

Where is the remedy? - Let me beg my readers to ponder these facts carefully and endeavour to realise something of what they mean in bitter struggle, hopeless indifference, deadening of finer feelings and impulses, recklessness, ignorance, animalism, and prodigal waste of life and energy. Is there any sane man who would not wish to see such a condition of things altered? But what is to alter it? One may contend that it is inevitable, but to say so is to take very low ground. It may be contended, too, that the main factor in the case is the personal equation, and that if things were equitably adjusted to-morrow they would be wrong again in less than twenty-four hours, owing to the idleness and viciousness of that part of the population out of which the dregs of society are formed. Granted the force in this contention, it still remains overwhelmingly true that it is the pressure of circumstances rather than the natural predisposition to vice which accounts for most of the sufferings of the poor; and, even if the sterner charge were abundantly justified, surely no compassionate human being could be content to go on enjoying the reward of virtue, if that reward meant living upon the produce of the labour of others, and entailed the infliction of misery and degradation upon masses of human beings whose life he never touched save 
to exploit it. In saying this I have no intention of indulging in superficial censures of the ordinary man of wealth, who is in many cases no more to blame for the unjust system by which he profits than a log of wood is to blame for the storm which flings it high up on the beach. In fact there are not a few rich men who feel that the present extremes of wealth and poverty are intolerable; but so long as the present system obtains they have almost no power to alter things. Charity is worse than useless. As a temporary measure it may occasionally have the same value as a stimulant in the body of a sick man, but systematically practised it is a demoralising influence. And if not charity - what? Here is one standing challenge with which Socialists may fairly meet all objections to the remedy they themselves propose. There is no individual and no party that can claim to be putting forward anything but palliatives in the effort to deal with our social sores. General Booth asked for a million of money in order to save the submerged tenth. He might have said the submerged half and not been far wide of the mark. He got it, and right nobly has he endeavoured to use it. Has he cut at the root of the evil? Assuredly not. Has he even made any great observable difference to the total of want and misery? He has made some difference undoubtedly, but the causes are as vigorously at work as ever which produce the wretched humanity to whose rescue this servant of God tried 
to come. It is no use, and will be no use, merely trying to save the wounded; we must stop the battle. We may as well admit, without any further demur, that whether Socialism be the remedy or not there is no other.

It is this discovery which makes one distrustful of the permanent value of the multitudinous activities of many of the churches in our poorer neighbourhoods at the present time. Not for a moment would I attempt to decry the motives of those who promote them, but when one reads down the list of Mothers' Meetings, Sunshine Committees, Temperance Societies, Soup Kitchens, and such-like, one cannot but think of the battle that is raging with unabated fury outside these temporary hospitals. It is noteworthy that many of the most earnest and devoted workers in the field of practical social service have been forced to the conclusion that, so far as permanent effect upon the poverty line is concerned, their efforts are equivalent to throwing good soil into the sea. It is a healthy sign of the times that an increasing number of the more comfortable classes desire to take part in such enterprises, but something more will be needed before they can begin to tell to any great extent; it is like trying to stop a leak with sugar. The same might be said of going to live side by side with the poor in the slums. "C'est magnifique, mais ce n'est pas la guerre." One cannot really share the life of the poor without sharing to the full in the 
anxieties and dreads caused by fear of unemployment and the consequent starvation, with nothing but the workhouse at the end of the long and weary road which leads to old age. If the saviour knows that he can leave the slum and go back to civilisation when he likes, he cannot really be a sharer from inside in the life of the poor he wants to succour, and he cannot help them out of their difficulties. He may try to teach them refinement, but they have not the equipment necessary for living on that level; environment is too much for them. Besides, what is wanted is not slum sharing but slum destruction, not bringing the rich in but getting the poor out; and that will never be done while the competitive system lasts under which one class does the work and another reaps the benefit.

The pooling of resources. - Here, then, is the problem, and the solution should not be beyond the wit of man. What is wanted is that labourer and capitalist should be the same person in the lump. It will have to be in the lump, because we cannot do without one another, and do not want to do without one another. If we could all go and live an isolated self-sufficient life on our own individual Crusoe's island, we might manage to get on and keep body and soul together, but it would be a poor performance at the best. We would rather have the slum with social companionship than an earthly paradise without it. 
"Oh solitude, where are the charms That sages have seen in thy face?

Better dwell in the midst of alarms Than reign in this horrible place,"

as poor Robinson himself is supposed to have soliloquised. But if in addition to social companionship we want ordinary comforts and the means to the enjoyment of a cultivated life, we can neither live nor work alone; we have to minister to one another's needs whether we will or no, and to every man his accustomed task. He who makes bricks requires a different training from him who makes watches; and the more complicated the product the greater the differentiation of function. It would be a useful exercise for the members of an ordinary middle-class family to attempt some time to count up how many hands have been at work to provide the breakfast table. Human society from the economic point of view is a most complicated structure, in which every real worker is in some way a contributor to the common good. Even now, under our present inharmonious social system, we find it impossible to dispense with one another's aid in providing the good things of life. Hence the necessity for reckoning the nation's wealth and labour in the lump; we can do nothing else if a truly civilised life is to be possible.

Abolition of unearned incomes and organisation of labour. - But, if we are to reckon in this way, private exploitation of the common store will have 
to cease, and that is just the issue which is now before us. All taking of rent and interest for which no equivalent services are rendered is robbery. If we could only succeed in getting rid of this horrible burden, the share of the actual producers of wealth would, of course, be proportionately greater; it would be multiplied by three right off, even as things are. But heroic measures of this kind, although in the abstract perfectly just, would prove futile without a better organisation of the national resources than we have at present. Under existing conditions production is more or less haphazard, every capitalist competing with his neighbour or with foreign countries as to who shall secure the markets, with the result that every now and then we have the glut known as over-production. It may be questioned, however, whether there is really such a thing as over-production; there is proportional over-production. If a few thousand hands are employed in producing toothpicks they represent so much energy withdrawn from the production of other useful and agreeable articles. The time will come when the community will require, not less toothpicks, perhaps, but more boots and shoes; the demand for toothpicks will therefore slacken proportionately; the makers will be thrown out of work and go to swell the army of the unemployed. They have now no means either of doing the work to which they are accustomed or of obtaining the boots and shoes which they need 
as much as other people; consequently production is disorganised, wealth goes to waste, and we have the melancholy spectacle of people suffering for lack of a commodity which could have been abundantly supplied to every member of the community if only production had been properly regulated. Clearly, therefore, what is wanted is that the community should be one big producing firm, after the fashion of the enormous companies which are springing into existence at the present time with the object of supplying the public with every conceivable object of desire from a sewing-needle to a flying-machine. Is this impossible? Certainly not, if we really wish to do it. I shall presently try to show how it could be done without dislocating any part of our present delicately poised economic machinery. The first and most enormous gain from such a salutary change would be the substitution of communal for private interest as the motive of production. In the name of human wisdom, not to speak of common justice, why should it be in the power of one man to say to another, "The thing you are now producing is for my benefit. I will give you a small share of the proceeds, but as soon as it ceases to pay me to have this article produced you must go away; I shall retain whatever possession in it may still have value; it is not yours, but mine"? If our eyes were not so blinded by what we have been used to we should see that such a practice is monstrous; the interests of capital 
and labour ought never to have been severed in any such way, for ultimately capital and labour imply each other; there can be no capital other than what is produced by labour exercising itself on the raw material supplied by Nature. This means that the only sources of wealth are the earth and the human ingenuity and industry brought to bear upon it. By what natural right or title does any man claim to appropriate one foot of the earth, and exclude his fellow-creatures from it except on condition that they shall gratuitously provide him with a share of what they draw from it? Rent and interest are therefore in origin immoral; they represent the expropriation of the many for the benefit of the few.

Communal responsibility for the individual. Still, as things now are, the ordinary private citizen cannot get rid of the necessity for making use of rent and interest if he is to provide for the future of those dependent upon him, or for his own sickness or old age. The community will not at present charge itself with the duty of maintaining either him or his in the standard of comfort to which they have been accustomed; the utmost it will do is to provide the semi-starvation of outdoor relief, or the humiliating alternative of the workhouse. Everything is done to discourage selfrespecting people from seeking these means of protection from want and misfortune, with the inevitable result that a class is created to whom 
self-respect is a secondary matter. This would not be so if it were plainly recognised that the natural resources of any community belong equally to all, and that, if labour combines to develop them, every individual member is entitled to take his share both in the development and in the result. Seeing that pure individualism is impossible, why should we continue to tolerate the hardships which accrue from partial individualism? The simple cure for the more obvious disadvantages of our present system, or want of system, is that the community should appropriate the whole of the wealth at present represented by natural resources as well as by rent and interest, and should then charge itself not only with the organisation of industry, but with the proper maintenance of every individual in the standard of comfort and well-being to which his equitable share of the common stock entitles him. This is the least that Justice would say. Christian principle would go farther, and affirm that the community should charge itself with the duty of caring for the weak and the disabled without any taint of pauperism. But there would have to be no drones in the hive. Not only would the right to work be fully admitted, but it. would be considered immoral that any man should expect to live without work. There would be no idle rich and no idle poor. Neither would there be any premium put upon inefficiency, quite the contrary. Those who did their work badly, or 
shirked their duty, or were without ambition and self-respect, would be the hewers of wood and drawers of water for the rest - not by special enactment, but by the sheer pressure of the conditions under which society can continue to exist.

To sum up once more. The object of our analysis of primitive, as contrasted with modern, Christianity has been to show that its original objective was the realisation of a universal brotherhood on earth, a social order in which every individual would be free to do his best for all and find his true happiness therein. But this is the fundamental principle of Socialism too. Even from the point of view of material advantage Socialism advocates the combination of resources for the common good. From the point of view of moral obligation it is still more closely in accord with Christian principle, for it desires the fullest individual self-expression for the enrichment of the common life; from the community it desires the best for the weakest. It believes that the highest kind of life is only possible when the material basis has been properly secured. It seeks to develop individuality by removing, as far as possible, the present barriers which hinder its expression in the average man. The situation for which it professes to find a remedy is obvious, the most glaring of its anomalies being that the vast majority of this nation - or any civilised nation for that matter - receives a comparatively small proportion of the total annual income, with the result 
that at least one-third of the population lives on or below the line of chronic poverty, thus diminishing enormously the corporate national efficiency which would otherwise be possible. In addition to the misery thus engendered is the narrowing of the mental and spiritual horizon through lack of leisure, comfort, and freedom from monotony. All remedies short of Socialism are of the nature of palliatives merely. What is wanted is the systematic combination of resources for the advantage of the whole community. Haphazard production would then cease, and we should avoid the waste which attends our present competitive methods. The more the community can produce the better, so long as production is properly regulated; we are collectively the poorer by every pair of idle hands which might be employed in producing something. The nation - and ultimately all nations working in harmony - ought to be one vast producing firm, with every citizen an active partner and shareholder. This would mean the abolition of the present gulf between capitalism and labour; since capital and labour are ultimately one, the capitalist and the labourer ought to be the same person. This will mean getting rid of the existing burdens upon industry in the shape of rent and interest paid to the non-producing members of the community. The industrial Commonwealth will then undertake the maintenance of every individual in that standard of comfort attained by the community as a whole, and considered to be the 
minimum requisite for general efficiency. Every one would be entitled to do and receive his share in the production of the communal wealth; idleness would have to cease at both ends of the social scale. Anxiety for the primal necessities of life would be a thing of the past. This is the true objective both of Christianity and Socialism. It may be more than this, but it is at least this. We have now to see how it may be most easily attained, and what further results may be expected from it. 


\section{CHAPTER VII}

\section{THE SOCIALISING OF NATURAL RESOURCES}

Difference in economic problems of primitive Christianity and modern Socialism. - It will be obvious from the foregoing that modern Socialism takes within its purview problems which to primitive Christianity were non-existent. If the followers of Jesus believed that the world was to be put right by Divine power descending suddenly upon organised society from without, instead of operating slowly from within, they could hardly be expected to foresee the methods by which Socialism proposes to achieve the same result to-day. Moreover, seeing that society itself was, in many respects, quite differently organised from what it is to-day, the same set of recommendations would not obtain even if the primitive Christians had been clear-sighted enough to go to the root of the economic causes of their social disabilities. The interesting little communistic experiment of the apostolic church at Jerusalem can, therefore, be of no assistance to us in solving our present-day problems, beyond the fact that it illustrates the spirit in which to approach them; it was in no sense the co-operative organisation of productive effort, it was only a generous sharing 
up of scanty resources for purposes of consumption.

Economics of ancient Israel. - But there was one respect in which the ancient religion which produced Christianity had lent its sanction to an economic ideal which still waits for realisation in the western world on a national scale. According to the law of Israel, the national territory was held to belong to God, and to be used only for the common good. In the Book of Leviticus are a number of interesting enactments regulating the use of the soil in an agricultural community. It will be seen from an examination of these statutes that ancient Israel went far in the direction of modern Socialism. Every fiftieth year was to be kept as a year of jubilee, in which every man was to be re-instated in his possessions, however unfortunate he might have been in the way of losing them beforehand. If he had been enslaved - that is, compelled by circumstances to work for the benefit of some private individual he was to be sent back at once to his family when the year of jubilee came.

"In this year of jubilee ye shall return every man unto his possession. And if thou sell aught unto thy neighbour, or buyest aught of thy neighbour's hand, ye shall not oppress one another" (Lev. xxv. r $_{3}, \mathrm{r}_{4}$ ).

"The land shall not be sold for ever; for the land is mine; for ye are strangers and sojourners with me. And in all the land of your possession ye shall grant a redemption for the land" (v. 24). 
"And if thy brother be waxen poor, and fallen in decay with thee; then thou shalt relieve him; yea, though he be a stranger, or a sojourner; that he may live with thee. Take thou no usury of him or increase; but fear thy God; that thy brother may live with thee. Thou shalt not give him thy money upon usury, nor lend him thy victuals for increase" (vv. 35-37).

"And if thy brother that dwelleth by thee be waxen poor and be sold unto thee; thou shall not compel him to serve as a bond servant. But as an hired servant, and as a sojourner, he shall be with thee, and shall serve thee unto the year of jubilee. . . Thou shalt not rule over him with rigour; but shalt fear thy God" (vv. 39, 40, 43).

These regulations are at least interesting as an honest attempt to prevent the natural wealth of the community from becoming concentrated in a few hands. Their basic principle is that the land is loaned by God to the nation, and is not to be monopolised by a fortunate few who are thereby enabled to live by the toil of others. That such a code of laws would be unsuitable for such a highly complex civilisation as ours goes without saying, but the ideal which here receives the sanction of religion is well worthy of reverence in any civilisation.

In another part of the Old Testament is a most illuminating description of the way in which monopolies in natural resources are created. In Gen. xlvii. we are told of the way in which a wily Hebrew Prime Minister managed to grab for the crown the greater part of the corn-bearing land of Egypt as well as the people who lived on it. 
"And there was no bread in all the land; for the famine was very sore, so that the land of Egypt and all the land of Canaan fainted by reason of the famine. And Joseph gathered up all the money that was found in the land of Egypt, and in the land of Canaan, for the corn which they bought: and Joseph brought the money into Pharaoh's house. And when money failed in the land of Egypt, and in the land of Canaan, all the Egyptians came unto Joseph, and said, Give us bread: for why should we die in thy presence? for the money faileth. And Joseph said, Give your cattle; and I will give you for your cattle, if money fail. And they brought their cattle unto Joseph: and Joseph gave them bread in exchange for horses, and for the flocks, and for the cattle of the herds, and for the asses: and he fed them with bread for all their cattle for that year. When that year was ended, they came unto him the second year, and said unto him, We will not hide it from my lord, how that our money is spent; my lord also hath our herds of cattle; there is not aught left in the sight of my lord, but our bodies and our lands: Wherefore shall we die before thine eyes, both we and our land? buy us and our land for bread, and we and our land will be servants unto Pharaoh: and give us seed, that we may live, and not die, that the land be not desolate. And Joseph bought all the land of Egypt for Pharaoh; for the Egyptians sold every man his field, because the famine prevailed over them: so the land became Pharaoh's."

The essence of monopoly. - This brilliant idea of Joseph's has been systematically practised ever since, though not always for Pharaoh. Nowadays it is being done for the financier; in feudal times it was done for the man with the strongest arm, whom the freeman had either to choose as a protector or an enemy - in fact, this is the way in 
which a good deal of the land of Europe has passed into the hands of its present holders. Monopoly in the gifts of Nature invariably means taking advantage of a fellow-creature's need. The monopolist may be the first-comer, or the strong-handed robber, or the cunning schemer, or the industrious worker - it matters not; but in any and every case his monopoly means that others have to work for him because they have to live. In Western civilisation the position of the monopolist is called a legal right, and is guaranteed to him by the community at whose expense he holds it. In this way practically every inch of the surface of this country, as well as the mineral wealth below ground, is owned by a comparatively few individuals. They own the fresh water, too, and would own the salt sea itself, in addition to all the fresh air and sunshine, if there were any practical means of establishing a permanent claim. If these things have not been privately appropriated and lent out to the rest of humanity on terms similar to the renting of landed property, it can only be because Joseph has thought the matter carefully out and decided that the thing cannot be done. If it could, we may be quite sure that a Company would be formed like the Standard Oil Trust to buy up the Atlantic Ocean and hire it out in bucketfuls to those who want to sail ships on it; or the air would be bottled, labelled, and sold at as high a price as possible to those who want to breathe. In principle there is no difference what- 
THE SOCIALISING OF NATURAL RESOURCES I8I

ever between privately appropriating lands, woods, and mines, and privately appropriating the atmosphere itself; the only difference is in feasibility.

Natural resources ought not to be privately owned. - Well, now, seeing it is plain enough that everything upon which manual labour can exercise itself for the supply of the primal necessities of life must come out of the earth, the sea, or the air, why should organised society be foolish enough to let these sources of our wealth - or any of them - be held for private profit? We have already seen that if a civilised life is to be possible individuals must combine. Robinson Crusoe might have owned the richest island in the world, but he could neither sink a mine nor build a steamship, even though he might know all about the way to do both. From the economic point of view two are more than twice one if they work together and specialise. If, then, combination is absolutely necessary for civilised life, why should the raw material of wealth namely, natural resources - be privately owned and administered in any civilised community? Perfect combination is impossible so long as a private monopoly is permitted to exist in the very things required by labour before it can produce anything. In the preceding chapter we noted that the price paid for permission to occupy and use the natural resources of this country, plus the improvements effected upon them by labour - that is, the lands, houses, mines, 
quarries, iron-works, gas-works, water-works, canals, fishings, shootings, markets, highways, and such-like - amounts to nearly $\$ 1,500,000,000$ annually. It is impossible to distinguish completely between the natural resources which have been improved in this way and other kinds of capital, such as machinery; as a matter of convenience, however, the classification is usually made somewhat in the manner now indicated. It should be pointed out in this connection that land or other natural resources have no real value apart from their accessibility to labour. It is labour that gives value to natural resources, even before it is directly exercised upon them; land in the neighbourhood of a market town, for instance, has a greater letting or selling value than land at a distance from it, although it may lie unused, and the legal owner may have done nothing either to improve it himself for the general benefit or to allow any one else to do so. It does not require much perspicacity to see that the value of such land has been created solely and entirely by the organised community around it, and yet, under the system of private ownership, that value is completely at the disposal of the individual in legal possession. But the truth is that all the land in this country which has a selling value at all comes under the same category, with the exception of those portions whose resources have been developed by the owner himself. It would be interesting to know what proportion of the total area has been 
thus improved; probably it would be found to be rather small - even the owner's improvements receiving the greater part of their value from the communal activities around.

Evil effects of private ownership of land. - When, therefore, we remember that less than I80,000 people own ten-elevenths of the land of this country, and that more than one-half is owned by 2500 people, the urgency of the problem of obtaining unhindered access to the natural resources of a territory containing between forty and fifty millions of people becomes fully apparent. These natural resources do not rightfully belong to private owners, for they are as necessary to the life of the whole community as the air we breathe. If to-morrow the whole of the landlords of this country were to determine, in a fit of madness, to expel everybody from the use of what is legally theirs, we should have an impossible situation at once, and no Government, however imbued with convictions about the sacred rights of property, would tolerate their action for a moment; in fact, it would instantly step in and claim the forbidden territory on behalf of the nation on the simple ground that the nation must live. If this can be seen so plainly hypothetically, why not actually? What is necessary to all should belong to all. Even supposing that the owners of land all did their utmost in making the best of it for the common good, this principle would still hold; for it is not well that the material source 


\section{I84 CHRISTIANITY AND THE SOCIAL ORDER}

of all the necessaries of life should be administered by others than those directly responsible to the community at large. But it is far indeed from being the case that the natural resources of the British Islands are being well and wisely developed for the benefit of the inhabitants. An enormous amount is shut away altogether from public use after the fashion we have just imagined to be universal; thousands of acres are being systematically kept olit of cultivation and turned into parks, sheepwalks, or shootings. It may be contended that this is better than using them all up for cabbage-beds, or squalid areas like the Black Country. Quite so; but even on this ground there is no justification for barring out the nation from its own and preserving it for a privileged few; it is not the land-owning class only that is capable of enjoying beautiful scenery and outdoor advantages generally. The practice becomes still more selfish when it means, as has so often been the case, that the actual cultivators of the land have been evicted in order that broad acres may be turned into hunting-grounds for plutocrats and their friends. The question takes on a still different aspect when it becomes a matter of wringing as much rent as possible out of the occupiers of dwelling-houses. Here we may indeed say that fresh air and sunshine are charged for, and that the charge is a heavy one. I take the following particulars from that useful little publication, the "Daily Mail Yearbook" for I907:- 
"The 300,000 London 'one-room' dwellers recorded in the last Census returns may have diminished in numbers, but it is doubtful whether any great reduction has been secured. It is true that a number of empty houses are to be found in several districts, but this means that in many cases unemployed workmen have taken their families to share the homes of relatives, thus actually increasing the amount of overcrowding.

"The Census figures of Igor showed that in the town groups of Scotland there were not less than a million overcrowded one- and two-room dwellers, and the figures are so striking that they deserve to be recorded here. In the Scotch towns there are $\mathrm{I}_{35}, 86_{4}$ families living in one-room homes, and, taking as the standard of overcrowding the presence of more than two persons to one room, there are -

74,832 overcrowded persons living 3 to I room.

\begin{tabular}{|c|c|c|c|c|}
\hline $7 \mathrm{I}, 880$ & 66 & 66 & " & \\
\hline 60,235 & "4 & "6 & "6 & 5 \\
\hline 40,272 & "6 & "6 & 16 & 6 \\
\hline 24,269 & " & 6 & 16 & 7 \\
\hline I 2,5 I 2 & " & 66 & $" 6$ & 8 \\
\hline $4,75^{2}$ & " & "6 & 16 & 9 \\
\hline I,940 & " & "6 & 66 & Io \\
\hline 595 & " & 66 & 66 & II \\
\hline 228 & " & " & " & $\begin{array}{l}\text { I2 } \\
\text { more) }\end{array}$ \\
\hline
\end{tabular}

or a total of $291,5^{15}$ overcrowded one-room dwellers in the town groups of Scotland.

"There are 280,447 families living in two-room homes in the Scotch towns, and, taking the presence of five persons to two rooms as constituting overcrowding, these figures show that there are -

205,665 overcrowded persons living 5 to 2 rooms.

$\begin{array}{llllll}202,096 & \text { " } & \text { " } & \text { " } & 6 & \text { " } \\ 178,045 & \text { " } & \text { " } & 7 & \end{array}$


I33,352 overcrowded persons living 8 to 2 rooms.

$\begin{array}{llllll}86,445 & \text { " } & \text { " } & \text { " } & 9 & \text { " } \\ 46,740 & \text { " } & \text { " } & \text { " } & \text { IO } & \text { " } \\ 20,273 & \text { " } & \text { " } & \text { " } & \text { II } & \text { " } \\ 10,476 & \text { " } & \text { " } & \text { I2 } & \text { " }\end{array}$

or a total of 883,094 overcrowded two-room dwellers in the Scottish towns.

"The rural housing problem still remains to perplex us, despite the laudable attempt to devise the £I50 cottage. In scores of English villages labourers are living in houses which are little better than worn-out shells, and the desire to build new and sanitary houses seems lacking in landowners and farmers alike."

To what is this all due? To landlordism. This statement may instantly be challenged, and fifty other contributory causes pointed out, but it is irrefutable. It is private property in land that is at the bottom of it all. If the land belonged to the State, and were administered for the benefit of the public, and not for private gain merely, slums and overcrowding would be impossible. Overcrowding is caused by high rents; high rents are the fruit of competition for dwellings near the centres of employment; landlordism, as in the days of Joseph, takes advantage of the people's need, and scoops off all the available gains of labour in the shape of rent. The rent paid to the landlord is simply labour handing over as much of its produce as can be spared for permission to live in a shelter which belongs to some 
one else. The conditions of modern industrialism are such that the workers have to be gathered around the machine; hence vast centres of population; hence, too, the opportunity of the landlord. When land in the heart of London mounts up to as much as $\$ 5,000,000$ per acre, it is clear that the aggregation of producing units in one spot is making a considerable profit for somebody.

What becomes of rent? - What becomes of the profit which is thus skimmed off in rent? Where does it go to? The $\$ 1,500,000,000$ a year which is carried off in this fashion represents a vast amount of skill and energy which is being employed in producing something; what does it produce? Now here is something for the thoughtful reader to ponder. It is commonly assumed that the expenditure of the rich finds employment for the poor, and the man who flings money about in a lavish manner in the gratification of his whims is therefore, as a rule, exceedingly popular. I can well remember in my Oxford days the way in which the townspeople cheered a set of sporting undergraduates who were being sent down by their college authorities for having given too violent expression to their animal spirits; the crowd hooted the dons vigorously, and loudly expressed the opinion that the expulsion of these young gentlemen was bad for trade. Their fixed idea, of course, was that the unproductive expenditure of one portion of the community was good for all the rest, because it 
kept people at work providing luxuries. The same conviction is stubbornly held by all the poor who obtain their livelihood by catering for wealthy patrons. When the Armageddon of Socialism versus Private Property really arrives, it will be this class which will fight the battle of the rich, and die in the last ditch, metaphorically speaking, in defence of privilege and injustice. It was just the same in the seventeenth century, when generous loyalist sentiment threw simple-hearted Englishmen on the side of autocracy in the struggle between King and Parliament. But what are the facts? Is it really true that money expended on luxury benefits the workers? No, it is not true; it is the exact reverse of the truth. It may benefit a particular class of worker for the time being, but it injures the community as a whole. In saying this, I do not lose sight of the fact that a measure of what is called luxury ought to be possible, and could be possible, for all; what I am contending for is that the luxury of the few is a wrong done to the many, and the truth of this statement will be evident to any one who asks himself what might have been done with the skill and energy represented in the making of luxury. $\$ \mathrm{I}, 500,000,000$ annually, remember, paid away as the rental of natural resources, only means that the owners of those resources have power to say to labour, "Instead of growing corn make jewellery; instead of boots and shoes make silk dresses; instead of houses for yourselves, 
build mansions for us." These are just the naked facts of the case, and there is no more gainsaying them than denying that two and two make four. Money paid as rent, or anything else, only represents power to command labour, and to tell it what to do; all the labour employed in furnishing the means of luxury is so much labour withdrawn from the production of the necessaries of life. Mind, I am not objecting to luxury as such, - although some philosophers might, - what I am pointing out is that the luxury of a section inevitably means the impoverishment of another section, so long as there is not luxury enough to go round. I do not say that all the $\$ 1,500,000,000$ paid as rent is spent in luxury; but I do say, and no one can disprove the assertion, that every person supported in idleness by means of that money, and every person who spends any of it in the gratification of luxurious tastes, is compelling labour to produce for him without any adequate return, and diverting labour from other channels where it might be more usefully employed. It may be pointed out that there is no guarantee that such labour could find employment elsewhere at all. I quite agree, and the reason strengthens my argument; it is that the natural resources of this country are privately owned and used for the benefit of a limited class, instead of for the whole community. Unemployment is caused mainly by two things - the comparative inaccessibility of the natural resources which should belong 
to all, and the comparative absence of anything like a national regulation of the ways in which the skill and energy of labour shall be employed.

How to obtain communal possession of natural resources. - How is all this to be remedied? How is the nation to be put in possession of its rightful heritage? Here let me pause to say that in pointing out how things are at present, and how cruelly they bear upon the millions who have thus been disinherited, I have no intention of railing against the owners of landed property or the many who live by rent and interest. Neither do I intend to inveigh against those who find themselves in circumstances which involve a large expenditure on what from the point of view of the poor would be termed luxury. If all this privileged class were to give up its possessions and go out into the wilderness to-morrow it would not alter things for the better; it might indeed make confusion worse confounded. It is the system, not the beneficiaries, that is to blame. Every day more and more of the individuals composing the privileged minority of the nation are beginning to question whether the system which puts such a barrier between them and their fellows is morally justifiable. No harder workers in the public service are to be found than amongst this very class. It would be unreasonable to demand of the heir to ancestral domains that he should step out of them and let them slide into other private hands which may make a less worthy use 
of them than he. It would be still more unreasonable to ask of the man who has invested his small savings in house property for the sake of his wife and children that he should refuse to accept a penny in rent or should hand them over to the public authority without compensation; he might find himself in the workhouse if he did so by the time old age came, and he would not have made landlordism one whit less strong than it is now. Even the millionaire with a taste for steam yachts might inflict hardship on the workers who have been trained to build yachts if he suddenly determined to employ his rents in directing labour into some other channel. Every such sharp transition involves suffering to some one. It would be mightily unjust, too, for the nation to say to the owners of natural resources, "These are not yours any more than your neighbour's; they belong to society, and we shall therefore resume possession of them at once." The uprooting would be terrible, and the general dislocation of trade and manufacture would result in chaos and throw civilization back for a good while. No sensible man would advocate such heroic measures; abstract justice of this kind would mean concrete injustice and untold suffering to thousands of innocent people who are no more responsible for the present system than the cogs in an engine wheel are responsible for the machinery that drives it. 
But there is a better way of doing things, once our eyes are open to the end to be achieved. The nation could resume its own, bit by bit, by buying out the monopolists, and it could be done without injuring anybody. This may seem like robbing Peter to pay Paul, but it is not really so. Some may consider that it would fail of its object because it would substitute hard cash for the ownership of soil, and therefore enable the monopolist to remain as much a monopolist as ever. Besides, it might be a dear bargain; such compensation would tend to become excessive in amount, and the payment of it would place a burden on our backs compared with which the existing National Debt would be a small matter. I admit all this up to a point, but beyond that point the objection breaks down. It is true that the hard cash would mean, just as rent does now, the power to command labour; but then there would be no more rent except to the State. That is just the point. Henceforth the nation would be in possession of the natural resources whence all wealth is derived, and could develop those natural resources as it pleased. The possessor of hard cash could go on for a time dictating to some extent the way in which labour should be employed in developing those resources, but his power of doing so would become less and less in proportion as the national organisation of industry became an accomplished fact. In the succeeding chapter we 
shall see what this organisation of industry involves. Finally the purchasing power of money in the hands of a private individual would disappear altogether; for in getting hold of the natural resources and directing the way in which labour is to be employed upon them, the nation would have full control of all the wealth that could possibly be produced. Money would then represent nothing; at present it represents the power to command labour, just because the sources of wealth are privately owned. When the sources of wealth are communally owned, every member of the community will be accounted a shareholder, and his share of the general produce will be secured to him. What will money in private hands be able to do then? Nothing whatever. It would have no power even now but for the fact that no man is sure of his portion of the wealth annually produced; the power of money is ultimately the power to take advantage of somebody's necessity. But under a system in which the community would be the sole employer, or at any rate could offer employment on terms with which no individual could compete, the mere possession of a long banking account would count for nothing so far as power over one's fellows was concerned. And even so far as one's power over commodities was concerned the case would not be very different. For a time the heirs of the dispossessed land-owners could use their bank notes as claims on the common store without having to do anything for it, and the amount they 
could take in this way might indeed be a Benjamin's mess. But this power would not last long either; several things would be ceaselessly working against it. The first would be the fact that with increasing communal prosperity the desirable things which are now attainable only by the few would be accessible to all; there would be comparatively little within the reach of the rich man at present which would not come within the reach of the average citizen too. A concomitant of this fact would be the disinclination of individuals to render menial service to other individuals, and this would automatically cause a great deal to happen. If the service of the public were considered more dignified than ministering to private luxury, as would certainly be the case, where would the rich man's staff come from? A constantly increasing proportion of his claim against the State would have to go in bribing servants to stay with him and minister to his pleasures. Where would be his grooms, chauffeurs, valets, masseurs, footmen, butlers, yatchsmen? All these would be finding new occupations, or rather, their children would be trained to serve the public - even, perhaps, in ministering to its pleasures - and would not care for the rich man's service unless they were paid far more highly than at present they ever dream of. This would mean a gradual lessening of the number of expensive establishments, and a coming to depend more and more on the advantages of public instead of private service. A third influence in the same 
direction would be the pressure of public opinion. In time it would come to be considered disreputable that any man should want to be waited on and catered for in the old familiar way. It would be thought effeminate - an unfair use of a word reflecting on the female sex, but we have no other which exactly expresses the same meaning - and selfish. One by one the children who were born to the claim, but who had never known the old system of private property out of which it arose, would want to take their place in the communal system and earn their share of the national wealth like other people. The few who were not amenable to such self-respecting considerations would be dealt with by the fixing of a time limit to their special privilege. Their nominal capital would be converted into a gradually decreasing pension - that is, a smaller and smaller share of the total annual produce until at length the whole of the material wealth of the country would be completely socialised. In making this forecast I am trenching a little upon the subject-matter of the remaining chapters, but the outline statement is necessary in order to show how the present legal owners of the natural resources of this country could gradually be expropriated with the least possible friction and individual hardship. I have taken for granted that the nation would be the economic unit, because in all probability national Socialism will long antedate international brotherhood, and is the practical objective at present. 
But there is no reason why in generations to come civilisation itself should not be the unit; and in fact with every advance of the social consciousness in any civilised community we may expect a commensurate advance in the desire for international fellowship.

The gradual development of communal ownership along with the ability to use it. - But, as I have said, the process by which the nation acquired unhindered possession of its own natural resources would have to be very gradual. If it were otherwise we should check the flow of production. It would be of no use taking over all the agricultural lands, for instance, unless we had all the administrative machinery ready for developing them to the fullest advantage. At present, in spite of agricultural depression, farming remains our most important national industry; there is no other single industry to compare with it. What should we do if all the responsibility for the management of this industry were thrown on our hands to-morrow without any trained body of experts to deal with it, and compensation to pay to the landlords? The immediate consequence would be a great outcry that the country was worse off than ever it had been under private ownership. No, let us get into harness by degrees. To begin with, it would be better that the localities should acquire the soil rather than that the State should do it directly. If, through lack of public spirit, any locality were backward in the matter, the State could step in, but only after communal farming in 
other districts had been proved a success. One thing should be made absolute: No land once publicly owned should ever be permitted to pass into private hands again. Hence everything in the direction of peasant proprietorship should be strongly resisted in the present, and strictly forbidden in the future; the national patrimony must never be alienated even to the actual cultivators. Besides, it is being abundantly proved that co-operative farming - especially with small farms - is more remunerative than individual farming. It is this, perhaps more than anything else, that is placing the British farmer at a disadvantage in comparison with his foreign competitor. On the Continent, but especially in Denmark, the institution of the co-operative system has resulted in a saving of labour and an increase of output which we in this country have not even approached. This has been strikingly brought home to me during the present year. I am a farmer in a small way myself - a typically bad one - but I felt curious to know how it was that Denmark could supply my own township with butter and eggs - not to speak of bulbs and garden produce generally - cheaper than I could do it on the spot. I learn that the explanation is chiefly to be found in the high state of efficiency to which the co-operative method has been developed under the guidance of the State in that little country. The Danes have a cheaper system of transport, and a good organisation both for co-operative purchase 
and sale. What is wanted in this country, side by side with the gradual extinction of landlordism, is the gradual extension of the co-operative system to agriculture, under communal control. The size of the farms should be regulated by the local authorities in accordance with experience of local needs. Agriculture is a science, and should be taught as such to every aspirant for this kind of employment. In time to come the State farmer will be a thoroughly efficient public servant, whose interests are those of the community, and can never be separated therefrom.

The amount of compensation. - As to the price to be paid as compensation to the landlords, there is not much to be said. The matter is easily arrived at. Granted that the power of compulsory purchase were universal, and liable to be exercised at any time on the basis of the rating value, there would be little opportunity for deception or for exacting an excessive price from the public purchaser. It would be to the interest of the owner to keep the rating value as low as possible and the selling value as high as possible. The two tendencies would regulate each other, and we should arrive automatically at something like a fair figure. These, however, are matters of expediency, and in the present work I am concerned not with expediency, but with principles. I only mention them to show what is practicable.

Housing. - So far as housing is concerned, some- 
thing more is needed besides getting hold of the land. It would be well to leave the land in its present ownership in some cases where population is congested, and put in force the sanitary regulations which already exist. If at the same time garden cities were established, and communally owned and administered, in all the outlying districts of our great centres of population; and if transit were cheapened by a system of public bounties on condition that railways and tramways became public property within a certain specified period, the value of what is at present slum property would speedily fall, and the landlords could be bought out more cheaply than would otherwise be the case.

The fundamental of the argument. - But, apart from all considerations of ways and means, my object in writing this chapter has been to establish one broad principle, namely, that as there is no wealth but what comes out of the natural resources of any country, those natural resources belong by right to the people who live in the country. All those people are living by those natural resources even now, but their access to them is hampered and hindered by private ownership. Moreover, if civilised life is only possible by combination of effort and specialisation of function, private ownership in the means of production is incompatible with the free development of such life; for perfect co-operation in effort is impossible without the common ownership of the objects upon which labour is to 
200 CHRISTIANITY AND THE SOCIAL ORDER

be exercised. I assert, therefore, that private property in natural resources is unjust, and a serious practical hindrance to the realisation of the highest kind of life for the community at large. I assert also that it is possible to put an end to this injustice without harming any one in the process, and that it is meet, right, and our bounden duty so to do. 


\section{CHAPTER VIII}

\section{THE SOCIALISING OF INDUSTRY}

Capital cannot be separated from natural resources. - We come now to a phase of our subject in which the practical difficulties appear to be greater and the issues involved more complex than in that which we have just treated. It is this feeling, no doubt, which, more than anything else, has led the followers of Mr. Henry George to confine their exertions to persuading the public of the advantages of nationalising the land altogether apart from the question of nationalising industrial capital. Many of them maintain, indeed, that the latter is neither desirable nor possible. But, as I now hope to show, there is no distinction in principle between the one proposal and the other, and if the former is practicable the same can be said of the latter. In treating the question of the socialising of natural resources apart from that of the socialising of industry I have only done so for the sake of convenience and clearness, and not because natural resources are essentially different from any other kind of capital. Natural resources are the potential wealth of the community; capital, commonly so called, is only that portion of those same natural resources upon which labour has been exercised with 
the object of turning it into an instrument of further production. Thus a sewing machine is composed of iron which has been dug out of the ground, and wood which has been brought out of the forest, the only difference between the natural resources (iron and wood), in their former as compared with their present state, being that labour has modified and combined them in such a way as to make of them a labour-saving device which will increase the output of wealth. This should be so obvious as to need no further demonstration. All industrial capital of whatever kind - plant, electric, or water power, etc. - consists only of natural resources so manipulated as to assist labour in the task of extracting from the same store of natural resources wealth which will be used for purposes of consumption. It is thus a misdescription to speak of capital as the result of saving or keeping back a portion of one year's wealth in order to increase the output in the next; it is only to a very small extent that the acquirement of capital can be said to begin in this way; it begins with the ownership of natural resources, and continues with the acquisition of the power to direct the way in which labour shall be employed upon those resources. It is even difficult to draw any practical distinction between the wealth which is employed for purposes of production and that which is purely for consumption. It may fairly be said that a man's food and clothing are capital, for they are necessary to his efficiency in the work 
of production. This, however, is to carry distinctions rather far. For all practical purposes we may define capital as natural resources plus what labour has done in fitting those natural resources to contribute directly to the production of the useful and desirable things which are usually designated as wealth. We all have a fairly accurate general idea as to the kind of things which are included under this head.

The consideration of this point plunges us at once into the highly complex problems associated with modern industrialism in its various aspects, and unless we limit our field we shall be in danger of losing ourselves in the very vastness of the theme. Our best method will be to adhere closely to the principle enunciated in the preceding chapter, and realise that, in spite of the greater complexity of its applications to industrialism, it is one and the same principle all through. If it be right and just to socialise the natural means of production, it is right and just to socialise the artificial means too; if it be right and just to socialise that by which the community lives, it is right and just to socialise the use which labour makes of it. If it be wrong and unjust for one portion of the community to appropriate and administer for its own benefit the natural resources by which all the rest have to exist, it is wrong and unjust to exploit the labour employed upon those resources. This is practically the whole case for the socialising of industry. 
The law of rent applies to all production. - For how are things organised at present? We have already seen in a preceding chapter that the nation's annual income is about $\$ 9, \infty 00,000,000$. Of this amount about $\$ 3,250,000,000$ goes in rent and interest, in addition to a sum of $\$ 2,300,000,000$ in "wages of superintendence." The amount left for the workers who actually produce the wealth is therefore about $\$ 3,450,000,000$. This means that about one-third of the total annual output is enjoyed by the workers who constitute the vast majority of the population. Roughly speaking, we may say that three-fourths of the population have to be content with sharing one-third of the income, while the remaining one-fourth takes two-thirds. The reason for this glaring maladjustment is the operation of the law.of rent, as it is called, which applies with equal force to the gathering of interest. Rent is calculated as the profit which accrues over and above the cost of cultivating the least desirable land in the community. It should be remembered that land has no value except as labour can be employed upon it with the object of producing desirable things. The only apparent exception to this rule is where land is allowed to lie idle for the sake of present enjoyment or future profit. But this apparent exception is no exception. What the land is worth is measured by the effective demand for it, which, again, is regulated by what it can yield to the community as the result of labour. This law holds just 
as good in the case of manufactures as in that of agriculture or housing, and interest can be calculated in the same way as ordinary rent, for, after all, manufacturing is only one way of employing the natural resources of the earth. But no labour will be employed unless the land will support labour. Some land will do this, and very little more, whereas other districts will produce abundantly. The Lancashire coal fields are more valuable than the Essex marshes, because of the productive power they possess. Now, whatever this total output may be, over and above the bare cost of the labour employed in producing it, is rent, interest, profit call it what you like. Who gets this profit? Who but the owners of the soil and the whole class they represent? How could it be otherwise? If their right to the control of land and capital - different names for the same thing, as we have just seen be conceded, there is no more to be said. They can dictate the terms on which labour shall be employed, and they will be certain to retain for themselves just as much of the profit as will remain after the wants of labour have been satisfied, and those wants will be sure to be regulated by the least that will maintain the labour at command on the least productive part of the natural resources of the community.

How it operates. - The way in which this law works out is clearly seen from the condition of the industrial world to-day. It may readily be con- 
ceded that we are no worse off than our fathers were, but it is practically certain that the poorest classes in the community to-day are no better off than in any previous age. For this iron law of which we have been speaking prevents any permanent improvement without the deliberate and sustained concerted action of the community at large. There is a clear line of division between the "haves" and the " have-nots," that is, between the people who own the soil and the people who do not. No increase in output will of itself improve the condition of the worker, for it only means a larger rent or interest to the owners of the sources of production; the remuneration of labour will still continue to be calculated on the cost of cultivating the least desirable of these sources of production. How true this is can be seen from an examination of the condition of unprotected labour even at the present time. It accounts for the sweater. It does not matter how large may be the selling price of an overcoat, for instance, if it be produced by sweated labour; the maker will only get the least that will suffice to make the production of the coat possible at all. Once this principle is clearly seen it will be recognised as sufficient to account for the enormous inequalities of our present social system. Since the outburst of productive activity which followed the invention of labour-saving machinery at the close of the eighteenth century, the output of 
wealth per head in this country annually is perhaps three times what it was before that period; but wages have not increased in proportion, for the simple reason that the law of rent is always in operation to keep wages down to the bare margin of subsistence. Of course a great deal has been done to raise wages, but that is only because labour has gradually awakened to a recognition of its own interests, and, by means of Trade Unions, has succeeded in obtaining a gradually increasing share of the prosperity thus made possible.

Consequent opposition of Capital and Labour. We thus get two great classes in any modern civilised country - the wage-earners and the wagepayers - and these two classes must stand over against each other as long as our present system of private property in capital continues. Their interests are essentially opposed, for every abstraction from the remuneration of the one means an increase of the wealth appropriated by the other. And the gulf between them tends to widen. It is becoming more and more difficult every year, as the organisation of industry becomes more and more complex, for a man to be able to force his way out of the larger and poorer class into that of the smaller and richer. We used to hear a great deal about the desirability of cultivating the qualities - such as thoroughness, patience, perseverance, and honesty - which would avail 
to raise a man in the scale of success; but we are now beginning to find out the absurdity of this kind of talk. The wage-earner may have all the virtues in the Christian armoury, but so far from helping him into the ranks of employers they are more likely to prove a hindrance in some respects. The admirable apprentice who marries his master's daughter is not to be found now outside the pages of fiction unless some lucky chance puts fortune in his way. How in the world is he going to get across the great gulf that separates the owner of capital from the servant of capital? There is no blinking the fact that our industrial system as we have it to-day is run on the lines of a modified slavery, and future generations will wonder that we did not see it, just as we now, looking back, marvel at the equanimity with which men accepted the hardships of feudalism. We fondly suppose that the ancient feudal maxim, "Every man must have a lord," has passed away for ever except in history books. The name may have done so, but the thing has not. It still remains true that every man must have a lord in the sense that every worker must have an employer. The only freedom he has in the matter is freedom to choose the employer or freedom to starve. $\mathrm{He}$ has no control whatever over the management of the business in which he labours to produce wealth for some one else to administer or enjoy, and he knows right well that if he makes any. fuss about it he will have to go, 
and that is just what he dreads the most. Capital has the power to give or withhold the right of access to the natural resources out of which the labourer's food and shelter have to be provided. The hours of toil may be long and uninteresting, but the fear of going without work altogether is just as real as the fear of the overseer's lash used to be in the days of "slavery" when slavery was not ashamed of its name. What we have to-day may be a little better, but not very much; and, whether we use the name or not, it still contains the essentials of slavery. And so it will remain until we have democratised industry as we have already democratised our more purely political institutions. Our industrial organisation is autocratic, aristocratic, bureaucratic, but it is not democratic, and never will be until the power of capital is taken out of the hands of a small class and vested in the community for the benefit of all.

Partial remedies for evils of individualism. I. Emigration. - A good many people are constantly putting forward remedies which they suppose would eliminate the evils of the situation without changing the economic basis of society. Thus we are told repeatedly that this old country is overcrowded, and that the young life should seek an outlet abroad, preferably in the Colonies. There is just sufficient truth in this suggestion to make it plausible. Of course it is true that the natural resources of a new country like Canada are more easily accessible 
than those of a country where every foot of ground has already been appropriated, and therefore for a time the pressure of the competitive system will not be so keenly felt as here. Any man who can have land for the asking would be foolish, especially if he has a little capital to enable him to develop it, to remain in a spot where he is more or less at the mercy of landlords and great industrial corporations. He may even be surer of finding employment in a country where there is practically no leisured class living on rent and interest, but only a whole community striving with all its might to develop its enormous resources of natural wealth. But no amount of emigration will really solve the problem at home, for the conditions are always at work which thrust men down into the ranks of the poor and physically inefficient. The law of rent under private ownership is only one of these; but it is sufficient by itself to produce most of the ills under which we suffer; for, if labour is unprotected, this law will prevent it from receiving more than what the worst paid labour will take. It should be pointed out that, after all, the Trade Unions have only as yet succeeded in organising the aristocracy of labour, so to speak. All the rest is subject to the direful operation of the law of rent in all its pitiless force. If labour will take less in any particular kind of work why should capital give more? Consequently we have the gradual lowering of the standard of physical eff- 
ciency in those who are forced below the level of remuneration which would keep them well and strong. The same law drives them into squalid dens for which they have to pay more than they do for food and clothing, and there is no escape from the evil effects of the conditions thus engendered. This alone would in time produce an "unemployable" class even if we started with a clean national bill of health to-morrow.

2. Temperance. - Temperance reformers tell us that to grapple properly with the drink traffic should suffice to cancel the worst effects of evil social conditions, and this argument, too, carries a certain amount of force when we realise that we are spending $\$ 820,000,000$ a year in intoxicating liquors, and that this represents an appalling harvest of poverty, vice, and crime, especially amongst the poorer classes. But I think it could be shown conclusively that there is some correspondence between the drinking habits of the poor and their narrow and uninteresting life, caused by the operation of the stern law we have been examining. The conditions of ordinary labour are such as to make toil repellent, and its remuneration is not enough to provide the wider life which would open up higher interests. Ignorance and recklessness are the concomitants of a lot in which ambition is useless and the outlook dreary and uninspiring. Excitement has to be sought in some way, and the easiest of access is the gin palace. This is a subject 
which we must mention again presently, but for the moment all I want to show is that the Drink Bill is partly caused by the conditions we are discussing, and that if by some miracle all the drinking saloons could be swept out of existence forthwith the conditions which make poverty would still remain as flourishing as ever.

3. Education. - The third remedy is Education. But our administrators are beginning to find out that the best education in the world is not worth much if it be not based on physical efficiency. The cruelty of forcing half-starved children to work for hours in a school room has at last forced itself upon the sluggish intelligence of the public, and we are beginning to face the question of the State feeding of the pupils attending our public elementary schools. But, even then, environment is more powerful than precept. The child who lives amid blows and curses in a slum is more likely to be influenced by that atmosphere than by his daily visits to the public institution where his mind is supposed to be trained. Besides, education will not give him work when he grows up; at the best it will only enable him to see a little more clearly where his disabilities spring from.

4. Protection and Free Trade. - Then we have the advocates of Protection and the upholders of doctrinaire Free Trade. But neither of these ever attempt to go to the root of the matter. Protectionist America has its problem of poverty just as 
we have it here, although probably not quite so conspicuously because of the vast natural resources which still remain untouched. But Protectionist Germany has it too, notwithstanding the minute Government regulations which make vagrancy difficult. Go where you like under modern industrialism, and you meet with the same extremes of the small, rich, or comfortable class on the one hand, and the large, poor, or uncomfortable class on the other. It is conceivable that a perfectly socialised State might have to adopt a Protectionist policy in order to preserve its markets from the influx of goods produced under conditions with which equitably paid home labour could not compete, or would not wish to compete at the expense of the foreign labourer. The Socialist is not so enamoured of the present results of half a century of free imports in Great Britain that he is prepared to declare himself a Free Trader at all costs. As Mr. Chamberlain rightly says, the producer has to be considered even for the sake of the consumer, and it is quite possible that foreign tariffs could be so manipulated under present conditions as to tempt capital away from this country to other countries. We might thus in time cease to be a producing country, and become a nation composed of a comparatively small group living on the interest of capital invested abroad - which only means living on goods imported from abroad - with a large servant class supported by their expenditure. Experience of 
pleasure resorts, where most of the resident population lives upon the expenditure of visitors, does not tend to make us welcome such a prospect on a national scale. The ideal is, of course, Free Trade all round, and the encouragement of the development of the natural resources of every country to the highest point of efficiency, but that we are not likely to get for a long while to come. The Socialist need not object to Protection as a practical expedient in the interests of labour, but he objects greatly to laissez-faire Free Trade, which is of the very essence of Individualism. Neither can he accept Mr. Chamberlain's proposals as a panacea for social ills. They will benefit the employer class, and that only, unless the present economic basis of society is altered. It is quite indefensible to say that our advance in national prosperity has been due to Free Trade; it has been due to the long start which England obtained in manufacturing industries, through the discovery of the steam-engine and other appliances for increasing man's power over Nature. But there are signs that our lead is coming to an end. In not a few cases Mr. Chamberlain's contentions are perfectly justified, in that a certain amount of capital has already been transferred from Great Britain to the further side of the artificial tariff walls erected by other countries. He is quite right, too, in maintaining that we must make haste to consider the producer - but which producer? As things are at present, the most elaborate tariff that 
could be devised would benefit the capitalist, not the labourer. If ever a Socialist Government should resort to Protection in any particular it would be with the object of benefiting the labourer rather than the capitalist, until the time arrives in which labourer and capitalist shall be identical on a national scale.

5. Profit-sharing. - There are other partial remedies, all of which bear more or less in the direction of Socialism without actually reaching it. Thus we have profit-sharing, as carried out in some of the most flourishing businesses in the kingdom, and experience of its operation goes to show that it pays. A public-spirited employer of labour like Mr. W. H. Lever, of Port Sunlight fame, will tell us that to raise the standard of comfort among the workers, and give them a direct interest in the prosperity of the concern they serve, increases their efficiency, and therefore adds greatly to the annual output. But, without seeming to be ungracious, I hope I may be pardoned for saying that such admirable efforts as those of Mr. Lever are only helps in the way of mitigating the worst evils of our present system. At the best they are of the nature of benevolent despotism. Mr. Lever is the benefactor, and his work-people are recipients of his bounty. Things are better for them than for other work-people because he chooses to make it so, not because they have any real-power over the matter. He is the sovereign of a petty industrial State, not the democratically 
chosen administrator of a Commonwealth. The conditions of citizenship in that community are for him to decide, not the people. If he pronounces a decree of expulsion, no man can say him nay; if he withdraws any portion of the benefits of membership, there can be no appeal. Behind all, after all, is the will of one man - the mediæval baron in a modern and more attractive form, but almost equally powerful. Can we do no better than this? I venture to think we can. It is not good that men should be kept in tutelage, even when they are well fed and housed; it is not good that they should be directed hither and thither by the waving of an autocrat's wand, even though that autocrat may be the most efficient administrator on earth. Let him and them feel that they have power to depose and replace him, and that their immediate interest in, and responsibility for, the well-being of the whole is as great as his, and the situation is at once altered for the better; he is no longer their master, but their fellow-servant, primus inter pares. This is morally sounder, without being one whit less economically advantageous. The real value of such experiments as those of Mr. Lever is that they help to show us how things might be in a well-ordered community, and put us on the track of solving some of our most pressing practical problems.

6. Co-operation and Peasant Proprietorship. The same criticism applies to the Co-operative movement. It is partial, not complete, an im- 
perium in imperio. It is in the right direction, but is not the final solution. As things are at present, the Co-operative movement only gives us one more industrial organisation with many small shareholders instead of a few large ones. And in any case the Co-operative movement is not going to capture modern industry; it could not do that without getting hold of all the natural resources whence capital is derived, and that will never be done till the nation does it as a whole. At the present moment some of the Welsh quarrymen expelled by Lord Penrhyn are manfully endeavouring to develop a mining industry of their own. As a temporary expedient it may be admirable; as a final solution of their problem it is useless. They have given us another little group of landlords, that is all; and things will go on much as they are until shareholder and citizen mean the same thing. It goes without saying, also, that such proposals as peasant proprietorship are in the opposite direction from what is wanted. They may benefit a small class for the moment, but they cannot benefit the community as a whole; in fact, they are in principle exactly the same as the system they profess to cure - that is, they are based upon the private appropriation of the natural resources which rightfully belong to all.

Expropriating the Capitalist. I. Transit. - We are thus forced back upon the one root-remedy explained in the preceding chapter, the communal appropriation and administration of the means of 
production. We have seen how this might be done in the case of land; we ought now to recognise that it is equally feasible in the case of what is commonly called capital. The greater complexity of the problem need not deter us from dealing firmly with it. The same set of reasons which render it unadvisable to get rid of the landlords at one fell swoop render it unadvisable to take over great industrial concerns all at once. To do that would be to disorganise production, for we have not the administrative machinery ready to deal with the situation which would thus be created. We have therefore to proceed gradually but surely in the direction of obtaining full communal control of organised industry by expropriating the capitalist. It would be quite worth while to buy him out in the same way as the landlord - for, indeed, he is the landlord in another aspect - but we need not pay through the nose for the privilege of doing so. We must operate on the line of least resistance in every individual case. It might pay us to nationalise the railways at once, for instance, by pledging the national credit to the shareholders as compensation for their private interest. The burden thus imposed upon the tax-payer would seem a large one, but it would only be so on paper. The real wealth represented by the railways would have passed into his hands, and would appreciate enormously by the unification of administration. For a time, just as in the case of the land, the compensated shareholders would go on using 
their amount of compensation as a private claim on the national income without doing anything for it, and precisely the same set of tendencies would gradually reduce this claim to zero. The purchasing power of the compensation granted would be vastly greater at first than it would a few years afterwards, and it would diminish in ratio as the general level of comfort rose (see above, p. I92, et seq.). But one great immediate advantage would be the cheapening of transit. There would be no need to insist that the railways should pay directly, it would be quite enough to secure that they should pay indirectly by causing the life-blood of the community to circulate more freely. The more mobile we could render capital and labour, the better for the general well-being. At present a great deal of the dislocation of industry at periods of depression in any one particular trade is due to the difficulty of transporting labour and appliances from place to place otherwise than at high rates. To many people it may seem revolutionary to say that transit should be as free as walking, but in time it will be seen to be enlightened common sense. We do not ask that the mighty stream of passengers who cross the thoroughfare every day in front of the Royal Exchange should pay for the pavement they walk on, and yet it has to be paid for. We have come to realise that, so far as general prosperity is concerned, it is more economical for the whole community to pay the cost of such up-keep, and so facilitate the flow of barter 
and industrial development. Think of the difference which has been made by the nationalising of the postal and telegraph system as compared with the time when people in ordinary circumstances could hardly dream of sending a letter from London to Edinburgh, because of the cost of transmission. If we were heavily taxed for the keeping up of the General Post Office, it would still be worth our while, for its principal benefits are reaped indirectly. It would be just the same with railways, tramways, canals, and even ocean shipping. The easier we can make it for people to get about the better, whether for work or play. If we find it to our national interest to keep up a fleet of war ships, why not a fleet of merchant vessels? It may take us a good while to arrive at this, but it will come as the necessary result of the gradual socialising of national industry, for we shall want to do all in our power to send out our goods quickly, or get them home with the least possible difficulty. Besides, there will then be no question as to whether it is just or expedient for one individual or one locality to pay for the transport of the goods of another, for every gain in the national output will mean an increase in the individual share.

2. Public Industries. - But this question of transit is only the outworks of the subject. It is a much more serious matter to know what to do when it becomes a question of taking over the capital at present employed in great concerns which are the 
fruit of individual initiative and enterprise, and perhaps do not always represent a permanent form of productive activity. New industries are always coming into being, and others are dying out. Ten years ago we scarcely knew anything of automobile manufacture; to-day it is one of the most prolific and rapidly increasing forms of industry. But suppose something arose to render it unprofitable or unnecessary, would it be worth the nation's while to buy out the proprietors of a decaying concern? Can we in any case face the enormous problem of buying out the private owners of industrial capital, without regard to the form in which that capital may chance to be employed? Is it conceivable that the community would ever want to assume responsibility for the sale of ice cream, for instance? and yet this appears to be a paying form of investment in some neighbourhoods.

Taxation of rent and interest. - The complexity of the problem thus illustrated shows that it is impossible to lay down any hard and fast rule for the attainment of the one grand end, namely, the communal ownership and administration of the sources of wealth. It may pay to buy out railways, but it may not pay to buy out the makers of "antique" furniture. It may be desirable to create a merchant fleet, but not to run a municipal rag and bone shop. It all depends on circumstances and public opinion. But there is no need to make a frontal attack 
on the numerous and intricate vested interests of this or any other country. The best and wisest way in most instances would be to go in for taxing profits, while at the same time safeguarding the interests of labour by fixing a minimum wage in every established industry. This method might be slow, but it would be sure. It would gradually draw the two extremes of society together. It would not remove all the disabilities of labour for a good while to come, for it would mean the dropping out of the unfit who are at present employed in place of the fit who expect better terms. It would prevent people, too, from adding to an existing income by accepting less than the standard rate of wages in some avocation in which they do not need to earn a living at all. It stands to reason that if an employer were compelled by law to pay a certain standard rate of remuneration, he would choose the most efficient labour he could get for the money. The undesirables thus weeded out would be a public burden while they lasted, but we should gradually be growing a generation of physically efficient and properly trained work-people which would no longer produce such undesirables. We know now where undesirables come from. They come from that gradual lowering of the standard of living which is the result of precarious employment and insufficient food. The minimum wage would stop that at the fountain head. We should gradually 
extend the area of this principle until practically the whole field of industry was brought within its operation.

The stock objections. - That there would be strong protest against increased taxation of the rich goes without saying. That protest is being heard now, and every year it grows louder. We are being told that it is confiscation and robbery, not to speak of a few other names which carry their origin on their faces. We are told that we shall paralyse industry by taking away that hope of reward which makes a man willing to work hard and do his best. We are warned that if we lay hands on the profits of industry we imperil that which makes it worth a man's while to exercise the prudence and foresight which have quite as much to do with the making of wealth as has the actual labour itself. Why should the man who, by the exercise of discipline and self-control, has made for himself a competence, be compelled to part with some of it in order to contribute to the support of the man who does as little as possible, and has never denied himself any indulgence within his power?

These are telling points if they really represent the facts; but they do not. At the present time the community as a whole is already compelled to support the idle and unthrifty class here alluded to. When a man becomes a wastrel, wrecks his constitution, and becomes a burden on society, 
we do not hang him; we feed him, and we feed him better than we do the industrious toiler who in his declining years puts up with untold hardships rather than go into the workhouse. We may do it grudgingly, but we do it. The rich man's argument only comes to this, that we propose to tax him rather more heavily than the rest of the community for what the whole community does anyhow, and which he can afford better than his neighbours. But this is not the whole of the argument. I would point out to the man of ample means that the system under which he has made his gains is one that inevitably produces paupers, and therefore it is just that he should pay the piper to a greater extent than those who have had to go without the gains. Most powerful of all, however, is the contention that the gains he does not want to surrender do not rightfully belong to him in any case. He has no real right to the lion's share of the communal income, and if he were morally enlightened he would not want it. Supposing every word he says to be true; supposing he has worked his hardest and done his very best; even then he ought not to claim such a share of the total output that his gain means other people's loss. The motive is wrong; he ought not to be working for gain, but for the joy of enriching the common life by doing a good thing well. I admit that as things are he has necessarily to think of ways and means for the sake 
of those immediately dependent upon him; but it would be far better even for his own happiness if, in doing his utmost for the community, he had no need to take account of material gain; he ought, therefore, to be using his power to further the promotion of conditions in which such a necessity would be a thing of the past. Besides, we do not want his money in order to give it to any particular class or classes within the community; we want it for the community itself. I have already shown that that portion of the profits of labour called rent and interest belongs of right to the whole community, and not to those who have privately appropriated the means of production; we therefore should seek to get this emolument out of private into public hands, and the best way of doing so is to tax the people who have got it now. We must keep on taxing these people until we have got it all. Naturally we should begin with unearned incomes, but we must keep on raising our demands until the whole of the material advantage at present possessed by the proprietary classes has passed under the direct control of the industrial community. Whatever buying out of the capitalist may then remain to be done will be a trifling matter. The true spoliation consists in resisting this process. It is perfectly right and just, and no argument but the argument of expediency could ever be employed against it. The State is morally entitled to do it at a stroke to-morrow, but the inconvenience and 
suffering entailed would render it undesirable to do it so suddenly. The best method of securing the desired end is, therefore, the one which statesmanship is already adopting by the sheer logic of circumstances.

Local versus national industrialism. - Such a process would have to be accompanied by a gradual increase in the number of industrial enterprises brought directly under public control, and this would necessitate a practical delimitation of the spheres of local as compared with national administration, which I am not prepared to discuss in these pages. No man can say beforehand what could be most profitably administered on a national and what on a municipal scale; that would have to be a matter of experience, and we should make some mistakes in buying our experience. Tramways, for instance, might be managed better locally, and railways nationally. But the great thing to recognise is that the organisation of industry ought to be as much a matter of public concern as the Civil Service, for it is just as necessary to the national well-being. What we need to do is to increase the national wealth as efficiently as possible, and to bring every citizen within its benefits. What is wanted is, as I have already said, that the nation should be one great producing firm with every citizen a shareholder. Already the big combines are showing us the way to do this, for they have proved conclusively that it is possible to secure 
a higher degree of efficiency by pooling resources and paying salaries to officials who have no direct interest in the total output than by keeping everything under "the master's eye," which, we used to be assured, was the only way to obtain success. The great industrial combines have proportionately lessened the cost of production by concentrating the machinery of administration, differentiating functions, and taking in as many branches of production as possible. The old maxim that in order to prosper a business must specialise is being falsified every day; the more a business can take in, and produce for itself, the more profit is it likely to make. If this be true on a limited scale, how much more on a national? If the salaried officer is proved efficient in a concern which is capitalised by a few thousand shareholders, and organised into a hundred different departments, he would prove equally efficient if the shareholders were the voters of the United Kingdom and the capital their united wealth. It may be pointed out that the operations of Trusts and Combines are international, and that it is therefore impossible to make the nation an economic unit. This may be freely admitted without weakening the force of the Socialist argument; on the contrary, it will but strengthen it. The mere fact that Trusts and Combines have it in their power at present to restrict output and force up prices should induce every civilised community to nationalise its own industries, for this means obtaining the 
control of markets and preventing any one class in the community from exploiting the rest. If any Trust or Combine outside the Socialised State were to discriminate against it, the results would not therefore be so serious as they could be at present. And in any case the aims of Socialism are international in their scope. It knows no desire to exploit one country for the benefit of another, for it rightly judges that in the long run this is an injury inflicted upon the perpetrator. The course here recommended is the one towards which the economic forces of the time are steadily tending. The small producer and trader, as well as the isolated specialiser, are gradually being eliminated by vast producing and distributing concerns which are turning what used to be proprietors into wageearners. The process is hard upon the immediate victims, but it is good for society; and it will have to continue until the wage system becomes universal, no servant of the public being exempted from its operation.

This will mean no degradation, no deadening of initiative, and no barrack system of control over the individual. The socialised community will do exactly what the big concern does now with those in its service; it will promote the best men to the best posts, and it will judge of their fitness by the quality of their work. In one respect it will differ from the big business of the present day, and that is that the less efficient will not be 
turned on the streets to starve. Every citizen a shareholder will mean that every citizen will be secure of at least the bare necessaries of life without the grinding anxiety and fearful drudgery in which at present so many of them have to live. This one result alone would be enough to justify the change.

Industrial statesmanship. - Our statesmen will be then what our captains of industry are now, and the field of their activities will be vastly enlarged. Instead of an order of professional politicians we should of necessity have every business man a politician and every politician a business man. Instead of our present high officers of State we should be asking ourselves what public man of business could be entrusted with the direction of the nation's railways; who should be qualified to control the nation's shipping; who should be administratively supreme over the nation's agriculture. If the nation's soap were considered of sufficient importance to have a department of its own, I have no doubt Mr. Lever would be at the head of it with a salary commensurate to his worth. His range of opportunity for the exercise of his remarkable organising abilities would be even greater then than it is now, and it is probable that he would value the position more. The Chancellor of the Exchequer would have to extend his horizon. In planning his budget the first thing he would have to allow for would be the probable amount of the primal necessities of life - food, clothing, 
230 CHRISTIANITY AND THE SOCIAL ORDER

and shelter - which the nation would require in any given year, and his basis of calculation would be the experience of previous years. This done he would know what probable margin of the nation's income would remain for the provision of other things. How that margin would be administered would be a matter of public opinion and demand. For this national organisation of industry means the provision of a wider life for all than we at present dream of, and it remains to be shown how this wider life can be brought about. 


\section{CHAPTER IX}

\section{THE SOCIALISED STATE: I}

The worth of the State. - In the preceding chapter I have ventured to indicate briefly what seem to me to be the principal tendencies at work in the direction of the socialising of industry. These tendencies cannot but culminate in a form of State organisation widely different from that with which we are familiar at present, although evolved therefrom. It is impossible to say what will be the outcome, say, a hundred years hence, but in broad outline it is already on the horizon, and those on the look-out are able to distinguish some of its outstanding features. The sketching of Utopias is always an interesting occupation, and in the hands of a master like Mr. H. G. Wells, who is even more of a political philosopher than a fiction writer, it may become profitable and inspiring to others. But I do not propose to attempt to describe an Utopian society. In the two chapters which follow I have set myself the humbler task of describing what is already on the way, and may fairly be expected as the result of the forces at work in our midst. In a word, we may say that our social organisation is gradually becoming moralised, in 
the Christian sense of the word, and the resultant will be the Socialised State.

What is the State? Do many of us ever ask ourselves what the State is for, or why we should take it for granted as we do? What is the good of the compound and perplexing facts called Great Britain, Russia, Switzerland, or the United States? To be sure we have to take them for granted, whether we will or no, but are they any use, and, if so, what? The thorough-going anarchist would answer these questions right off by saying that the State is no use whatever, but only a hindrance to the best kind of life for human beings, and, therefore, that it is desirable to get rid of it as soon as possible by assassinating rulers and paralysing governments. He will maintain that after this immediate end has been achieved things will settle down comfortably, and that we shall be able to get on all the better without artificial restraints. But this will not do at all, and no ordinary sensible man would concede its reasonableness for a moment. If every human being on earth were suddenly to wake up to-morrow with an ideally unselfish disposition; if all criminals were transformed into saints; if prisons, workhouses, and lunatic asylums were no longer needed, we should still require to be communally marshalled and directed if we wished to live the best kind of civilised life possible to human wisdom and power over Nature. As I have shown above, we should have to combine in order to produce material 
wealth efficiently; and without such combination even the principal advantages of leisure and culture would be impossible. If, too, the wider the scale of such combination the greater the proportionate output, it follows that at present, and for a long while to come, the State will have to be the final unit of economic organisation for the sake of realising the best kind of life. The time may come when the whole world will become one centrally directed society of societies, with the sole object of doing the best for mankind without discriminating in favour of any individual or race. But the most daring dreamer will hardly attempt to forecast what may happen then or what the world would be like. At present, therefore, we may content ourselves with the recognition that the State is de facto the most convenient unit for the organisation of society on a socialistic basis. The electors of Great Britain can determine, for instance, what shall be done in this country, but they cannot lay down any rules for Germany; even for the sake of mankind, therefore, our most earnest effort should be directed towards socialising the potentialities of this one country. Even as things are already, the civilised State is the principal guarantee of that comparative order and safety without which production, on anything like an elaborate scale, would be impossible. We have only to extend this in order to make the State not merely the guardian of production, but its intelligent director. This, then, 
is the principal value of the modern State. It is a necessary means to the realisation of the highest kind of life at present in our power to achieve. Man was not meant to live alone. There is no individual excellence which does not require a social expression, as we have seen when considering the controversy between Jesus and the Pharisees. No human being can be good or wise apart from his relation to other human beings. The better those relations can be adjusted, therefore, the better for the quality of the individual life.

Material basis of all higher life. - But, again, this objective requires the careful and harmonious regulation of the material resources of the body politic. "Man cannot live by bread alone," but neither can he live without bread. The greater our communal command of the potentialities of the material world in which we live, the greater the extent of our spiritual possibilities. This may be hotly denied by some moralists and some religious people, but it is surely demonstrable from ordinary human experience. To live for luxury is a bad thing, and may lead to the overthrow of a nation, but that is only because the means have been mistaken for the end. What is ordinarily called materialism in practice is but spirituality foreshortened; it is the taking of a wrong perspective upon the meaning of life.

Wealth means power over life. - In order to demonstrate the truth of this observation, let us 
ask ourselves why any man wants to be rich. The form of the answer depends partly upon temperament, but I suppose we should all admit that one reason is that as things are at present the possession of wealth means power over others. In fact, we might quite truly say that individually or communally the acquisition of wealth means the acquisition of power over life. But many men value riches chiefly because they represent power, consideration, and rule of a certain kind in one's relations with one's fellows. It is no use decrying this motive, for it is very strong, and human nature is largely constituted that way. There is an old saying that money is power, and so it unquestionably is in the world as we know it. The man with money can force his way into almost any society he chooses. If he is large-minded enough not to care for the society of dukes and duchesses so long as he can exercise practical influence in society at large he can do many things that the ordinary man cannot, even if possessed of education and social advantages. If his financial operations are on a gigantic scale he can even make kings and governments take him into account. Rumour has it that he can make wars between nation and nation occasionally when it suits his purpose. If he wants to cut a figure in national politics he always has a long start over the man of limited means. If he is fortunate enough to have brains as well as money he is generally sure of one of the foremost positions in the 
State, and does not need to wait until he is old in order to get it. If he is of a philanthropic turn of mind he can endow educational institutions, scientific research, hospitals, and such-like. If he is utterly misguided he may endow theological seminaries, but he is not often so foolish. In any or all of his activities the man of wealth is a man of power. He can set things in motion. He can say to one man, Go, and he goeth; to another, Come, and he cometh; and to his servant, Do this, and he doeth it. For good or for evil his power is always great, and, as a rule, he likes exercising it. This is one exceedingly potent motive behind the desire to be rich.

Wealth necessary to fuller life. - But there are other forms in which the same desire expresses itself. Most people want wealth because it means command of liberty and pleasure. It gives possession of useful and agreeable things; leisure, and change from monotony; the advantages of travel, culture, refinement, and acquaintance with the beautiful. In a word, it stands for more abundant life. Poverty means a narrow life, and therefore one does not want to be poor. The poor man, as a rule, is chained to one spot and one occupation. His interests are few and his range of activity is small. Culture, refinement, and all the desirable experiences which require leisure for their fulfilment, are beyond him. Naturally everybody would prefer the wider life, and hence when a rich man 
opposes Socialism he usually does so from the fear that Socialism would take this wider life away from him. His fear is groundless, but quite natural as things are at present. The fear may be a selfish one, but we cannot be surprised that it exists. And yet, as I hope to show, the realisation of the principles of Socialism would take nothing from the rich man that he at present enjoys except his power of exploiting the labour of others. So far from making his life narrower, Socialism would widen it. It would not necessarily deprive him of his power over other men, but it would prevent that power from being exercised against their will. For, let me point out, even now there is a nobler way of obtaining power over others than is supplied by the mere ownership of wealth, and it is a kind of power which is tending to increase as time goes on. I refer to the power of special merit and ability as exercised in a democratic State. Thus a statesman like the British ex-premier, Mr. Balfour, sprung from our hereditary aristocracy, counts it worth his while to serve the public in an office to which he is elected by the free choice of his countrymen. In this respect he is at once on a level with the able plebeian administrator who at present presides over the Local Government Board. Is not this significant? Here is a man of literary and philosophic tastes who might employ his ample means and leisure in living an easy life at the expense of the workers of the community, but, on the contrary, 
he chooses the arduous and exacting life of a public servant in which the financial remuneration can be no object to him. Evidently he prefers the power which comes to him through the effective expression of public opinion; and neither less nor more could be said of a Labour member of Parliament. This is a far worthier motive for the exercise of power than that which is associated with great material possessions. In the former case it is dependent upon the free consent of the community; in the latter it is not. As things are at present the exercise of the higher kind of power is hampered and deflected to an enormous extent by the existence of the lower; what we want is a state of society in which the lower shall no longer exist at all, but the community shall be free to discover and make use of its best individual talent in any and every department of the public service. Only in this way will the wider life at present associated with the possession of wealth become possible to all. With the passing of the power of the present ownership of material resources will come the power to enjoy communally the benefits of the leisure, culture, and ampler opportunities at present within the reach of the rich alone.

Individuality under Socialism. - Let us try to. imagine a condition of society in which the material means of existence would be communally owned and administered. Imagine the responsibilities of our statesmen, as indicated in the last chapter, to be 
so extended as to cover the whole field of our industrial activities. Imagine that there was no longer present to any man's mind the harassing anxiety of questions about food, clothing, and shelter. How much larger and nobler would become the field of legitimate ambition under such conditions! As society is organised at the present moment, true individuality is crushed and hampered in a thousand ways. When we meet the ordinary poor man of native ability, do we never wonder what he might have been if his faculties had been so trained as to enable him to appreciate the best that has been thought and said in the world, and to add his quota to it? If refinement is a good thing in a countess, why not in a laundress? What absurdity to talk of the development of individuality in a society in which three-fourths of the population have to toil so hard that leisure is a rarity, and the means to refinement exist only for the few! What higher life is possible without a material equipment? We may go on pointing out as long as we please that the truest individuality has been developed under adverse conditions, like those of the Scottish University students before Mr. Carnegie came to their rescue; but a little reflection ought to convince us that there is no reason in the nature of things why it should not be better still in a more perfectly socialised community. The reason why luxury often operates as a deteriorating influence upon character is that it exempts its possessor from the 
necessity of working. In the socialised State there would be no such class; as the material basis of life would have to be provided somehow, labour would be absolutely necessary, and no one would be exempted from the duty of performing his share. Under such circumstances individuality would find expression on a scale which is not possible now. It would not be a man here and there who would be free to be and give his best to the community; with greater leisure for the many, better education, the opportunities of general culture, and the elimination of anxiety for the necessaries of life, powers would be released in the ordinary man which can never find expression so long as the present system lasts.

The wider life made universal. - It may be thought that this is only an unpractical dream. It may be contended that under the new order the life of leisure and refinement would be as impossible as now for the unprivileged majority. At present the many have to work even to the extreme of drudgery to make this wider life possible for the few. How could it be otherwise in any system? Would there ever be leisure and luxury enough to go round? Is it conceivable that the general level of refinement and culture could possibly be as high then as it is now for the privileged classes? Well, even if it were not, one could gladly welcome the change if only to get rid of the blood and agony which the cultured life of the few costs the whole 
community now. If the slum is the price we have to pay for refinement and beauty at the other end of the social scale, then let us go without refinement and beauty, or, at any rate, put up with less of them; it would be well worth the sacrifice. But, believe me, no such sacrifice would ever be needed. In our folly at present we imagine that the privileged would have something to lose if their brethren in the outer darkness were called in to share in the banquet of light and joy, whereas the fact is we are losers already by not having called them in sooner. If the change advocated by Socialism only means a change in the way of benefiting the few at the expense of the many it would not be worth while to trouble our heads about it. But it is not so. We have never yet tried what combination can do on the grand scale; we have only tried it timidly and uncertainly. The greatest indictment of the competitive system is its wastefulness both in wealth and workers. If, even under our present cruel and wasteful system, combination and labour-saving machinery between them have been able to treble the annual output of wealth per head since the rise of modern industrialism, what may we not expect when their joint operation is made more efficient? It is hardly to be supposed that we are more than at the beginning of what the increase of labour-saving appliances will enable us to do. We may reasonably hope that manual drudgery will be considerably reduced, but even if it were not so, the tendency of things is 
already in the direction of making the cultured man less shy of manual labour. The skilled artisan is proud of his trade, and there is no reason why the time should not speedily come when it will be considered a disgrace for a man to be willing to be a useless parasite upon the labour of others. In all new countries the difficulty of obtaining servants is driving the well-to-do classes to perform services for themselves which were formerly considered menial occupations; as wealth becomes socialised the same tendency will show itself equally everywhere.

Even now a moderate income can command the wider life. - But, without labouring this point, let us appeal to facts which simple observation will suffice to prove. In Mr. Bernard Shaw's suggestive little pamphlet, "Socialism for Millionaires," the statement is made that modern production is tending more and more to cater for the wants of the many instead of the few. The higher an income the less its proportionate purchasing power. The man of wealth can have the best of everything, it is true, but in this respect he is not much better off than the man of modest means. The only advantage he possesses in the way of luxury is that he can skim the cream off the commodities produced for general consumption. He can purchase a ten thousand dollar motor-car - he can purchase ten of them if he likes, but he can only use them one at once. The man of limited means can purchase a five hundred 
dollar car and do almost as well; the only advantage possessed by Dives is that he happens to have got the better car of the two, that is all. It is much the same with anything else. The man with the smaller income can give his son as good an education as the millionaire. He can live in a house just as beautiful, though not so large. He can employ his leisure just as happily, perhaps a little more so, because he is never in danger of enmui. He cannot own a private yacht, but he can pay his fare on a public one which is quite as good. There is hardly any place the millionaire can visit which he cannot visit too, thanks to co-operative touring. He cannot afford to keep up expensive grounds and orchid houses, but equally well-kept public parks are open to him, and he can visit Kew Gardens - or similar flower treasuries - whenever he pleases. Almost the only difference between the man of moderate income and the millionaire is that the latter possesses the sinister power over others, already alluded to, which he ought not to have; there is hardly any requisite of a refined and cultured life in which the one is not as well off as the other. Be it understood I am now pointing out the opportunities enjoyed by the man with, say, an income of a few hundreds a year as compared with the man who is master of as many thousands or even millions; but I do not lose sight of the fact that even this man of moderate income belongs to the financial aristocracy, as wealth is at present distributed. The point of the com- 
parison is that if all the members of the community were only as well off as the average professional man is now with from fifteen to twenty-five hundred a year, there would be very little which great wealth can procure which would not be open to everybody. Co-operative consumption. - Can this be done? Most assuredly it can. Even now, as we have seen, the annual income of the United Kingdom amounts to at least $\$ 870$ per adult man. If we measure by the family it should be larger still. We may say that probably the average income per family is not less than $\$ 20$ or $\$ 25$ a week. Imagine the purchasing power of this sum socialised. Imagine the effect of combination on a grand scale with even this amount as an equitable basis to start from. Imagine all the means to a full and interesting life, such as the rich man can at present enjoy, communally owned and administered. Imagine the lessening of waste, and the gradual raising of the average power of production consequent on the improvement in physical efficiency and mental alertness in what are now called the lower classes. Why, if the national income has trebled once it could be trebled again, only we should no longer measure by such symbols. Such appurtenances of capital as are now represented by palatial establishments would no longer exist except in public use. It is obvious that not only would the means to a healthy existence be assured to 
all, but even a measure of luxury too. After the Chancellor of the Exchequer had made sure of the required amount of the primal necessaries of life - and that could be done by ten million workers working from four to six hours a day - public opinion would begin to demand other desirable things, and there would be a sufficient margin of wealth under the new conditions to render them possible. But in most of the things which are now the private preserve of the millionaire private property would no longer exist. There would always have to be private property in some things, to be sure; men could hardly share in the wearing of coats and slippers, for instance. But practical convenience would settle all such points without the necessity for special regulations. It would be more convenient for the industrial community to retain the public control of taximeter cabs - the communal motorcar - but there would be no rule to prevent an individual from acquiring one for his own private use if he chose to expend his share of the communal income in that way. But probably few would wish to do so; it would be more convenient to acquire the individual use of such special facilities at the special times when they might be wanted. Communal ownership would thus largely mean co-operative consumption as well as co-operative production, though not always of necessity so. Individuality would 
here come into play. Granted that the citizen shareholder were able to use his equitable share of the communal wealth as he pleased, there would be nothing to prevent him doing so up to the limit of his resources, and it would be a matter of individual taste how he employed his leisure or what kind of facility he would require in so doing. One man would sail and another would fly; one would read and another would paint; one would career about in an automobile and another sit alone on a mountain-top. But there would be nothing whatever to prevent us from individually employing our share of the national income exactly as we pleased in making use of what was communally produced. The demand would create the supply of the kind of things required. If there were not enough public steamers one year, there would have to be more next year; if there were too many, we should build less. If there were either shortage or waste, or if there were undue delay in satisfying popular demand, we may be quite sure that the aggrieved Briton would make his voice heard in protest, and roundly declare, by means of platform and press, that such a scandalous state of things had never been known before! Whereat some who could remember the good old times when millionaires and slums existed would smile and bid the angry citizens be patient. Governments might not go in and out of office as they 
do now, but individuals would. Every minister of State, who would ipso facto be a director of industry, would come under the sharp scrutiny of public opinion, and, if proved inefficient, would be replaced by a better man. Competition there certainly would be for the best positions, and, poor human nature being what it is, there would doubtless be some disappointment and heart-burning when a great office fell vacant which only one man could fill, and thousands of capable men ready to fill it. But this kind of competition would not be so cruel or unjust as that which operates now; it would not be competition as to how little a man would take for his work, but how much he ought to have. Just as at present we have a standard rate of wages for an Archbishop, so in time we shall have a standard rate of remuneration for every position in the industrial Commonwealth. We shall not stint the men at the top, but their advantage over their fellows will be small compared with what it is now, from the purely financial point of view; our first care will be to guarantee the minimum standard of physical efficiency and comfort necessary for every member of the community. We shall feel that we can no longer afford to neglect this, for our present experience will have taught us that the general level of efficiency is bound to suffer if we do. Once this is done we can begin to talk about the 


\section{CHRISTIANITY AND THE SOCIAL ORDER}

special emoluments to be attached to positions of special dignity and responsibility.

The worker and the child. - One thing should be clear from the foregoing: there would be no point in getting rich, for the very things which riches can obtain at present would then be accessible to all without pauperising any. There would be no anxiety for old age, for the birthright of every citizen would be a share in the production of the national wealth, and maintenance from the common store when his working days were over. If he chose to save part of his annual income during his productive period, so as to increase his claim on the State in his declining years, there would be nothing to prevent him, but he would not be able to pass on his claim to his descendants. The utmost that a man could do for his children would be to supply them with the best moral training and atmosphere the home could furnish, and direct their growing energies into the most șuitable channels of communal service. The State would educate, and probably even feed them while they were under public tutelage; the duty of the parent would be to give them that individual care and affection without which the work of the State would leave much to be desired. It is sheer nonsense to say that with the removal of direct parental responsibility for the feeding of children the tie between parent and child would be weakened, or idle and selfish habits be encouraged. If it is not so now 
with the grant of universal, free, compulsory, elementary education, why should it be so with regard to food? The tie between parent and child would be strengthened rather than weakened with the raising of the general level of refinement and courtesy. Our existing slum neighbourhoods are hardly ideal atmospheres for the encouragement of parental responsibility; indeed it is just the other way about. But even under the most ideal social system the guiding hand of the parent would always be wanted in shaping the career of a child. It would be the parent who would note the budding talent as readily as the schoolmaster, and have the largest influence in the choice of the institutions in which that particular talent could best be developed. There would be no more barriers of privilege to prevent him from placing his child under the best tuition the community could provide. Every kind of educational facility would be absolutely free and open; this would be the truest economy from the point of view of society at large. If a mistake were made in the choice of a vocation, as might easily happen, it would not be irremediable; with the abolition of excessive hours of labour there would always be sufficient leisure for any youth or man to prepare himself in public institutions to enter some new field of activity. There would be no reason why any individual should not keep on attending such institutions as long as he pleased, provided he was not shirking his daily 
duty in the calling he had first chosen. The provision of the fullest technical training, without restriction of any kind upon applicants, would be a necessary accompaniment of the socialising of industry. It would be to the highest interest of the State to see that every craftsman was as thoroughly trained as possible for the kind of work he had chosen.

The regulation of the influx of labour to the several trades. - That there would always be a certain amount of maladjustment goes without saying. For one thing, no matter how carefully production might be regulated, there would have to be some displacement of labour at certain periods in certain trades caused by the falling off in the demand for the particular commodity produced by that trade. It is difficult to see, for instance, how as many bricklayers could be employed in winter as in summer, and, if not, what would become of the surplus? The same might be said of all fluctuating occupations. At the bottom of the industrial scale, therefore, we should always be liable to have a class of non-efficients, the overflow of the various trades and professions, and there would have to be a kind of employment provided for them which could stand still or go on, according to the demand for labour in other fields. Such kind of employment would be that so often recommended in these days as temporary relief for the unemployed, namely, recla- 
mation of foreshores, afforestation, and other simple works of public utility. But even this would not be enough. The flow of labour into the various channels of public service, even under ordinary conditions, would have to be regulated, although it would only be in rare circumstances that any youth would be prohibited from entering any special industry. If there were too many clerks, for instance, the difficulty would not be met by lowering wages, or even by closing the door to fresh applicants from the public schools, but by publishing the facts and showing where the best openings were to be found. Entrance into overcrowded trades or professions would thus be discouraged. Those who nevertheless persisted in the choice of such a field of activity would have to take the risk of dropping down into the fluctuating class for whom relief works were provided, and whose number would be large or small, according to the demand for service in the ordinary departments of industry. There would be no " unemployable" class, for there would be no idle, under-fed class from which it could be recruited. It would be no charity on the part of the community to find work for the temporarily displaced; enlightened public opinion would realise that the community was richer by every pair of hands employed, and poorer by every pair unemployed while the mouths belonging to the hands had to be fed. 
Worthy and unworthy demand for commodities. Another thing which would certainly be changed for the better would be the kind and quality of the production which would be permitted or encouraged. At present a great part of the energy of the community is misdirected in the matter of production, because of the whimsical and eren evil requirements of those whose possession of wealth enables them to make an effective demand. How could it be for the benefit of the community, for instance, that some extravagant woman should have power to keep a whole establishment, or half a dozen establishments, working night and day to produce the materials for a "freak" dinner or ball, to which every guest had to come habited in a style which would never be worn again, and in which the various viands and decorations had cost a fortune to provide? Such senseless extravagance is wicked, because its only object is eccentricity or display, and the labour withdrawn from really productive occupations in order to make it possible represents an amount of human misery which cannot be estimated. This is the simple truth, although we seldom look at it that way. When the poor go hungry or cold it may be because the food and clothing which they need are lying unused in storehouses which they have not the means to unlock; but it may quite as readily be because the labour which should have gone to the production of that food and clothing is being wasted in the gratifica- 
tion of extravagant folly. In a properly socialised community such a wrong kind of demand would be impossible. Private extravagance would no longer have the power to compel labour to do its bidding on such a scale, much less to divert production from healthy and needful channels. As the public good would be the object of industrial administration, so would public opinion be the arbiter as to what constituted the public good. If public opinion should suddenly decide to go in for headdresses of peacock's feathers, and fashions should set that way with a rush, the most levelheaded of industrial administrators could do nothing but bow to the demand; but if, on the other hand, only a few eccentric individuals decided for this course they would not find their tastes gratified; the captains of industry would not consider the demand a legitimate one.

People who cannot work by time and rule. There is one class of employment to which it may be thought the considerations contained in this chapter do not apply, namely, the small but specially gifted class whose best work cannot be done by rule of thumb or at any given time, but only as the afflatus comes. A mechanic can hammer a table together in a given number of hours, and every hour will represent just so much work; but an artist in letters or colour will not be able to proceed in that way. If he does, the quality of his work will necessarily be poorer. How is this difficulty to be met? 
What place will the socialised State reserve for genius? Probably the socialised State will treat genius almost as badly as it is treated now; that is, it will misunderstand and browbeat it until it is dead, and then build it a fine sepulchre or endow scholarships to perpetuate its fame. This is a way which human nature has, and it is not to be supposed that it will change greatly from age to age. The man who is different from other people must expect their disapproval and probably their active hostility; if he has a real message to deliver he will have to go into the wilderness until the time comes when that message has done its work. Loneliness and persecution are likely to be the lot of the sons of the morning to the end of time.

But, granted this is so, it can hardly be that the future will be altogether so sad and dark as the past for the being whose value to the community consists in what he does in hours of special inspiration and insight rather than hours of plodding industry. If, even now, the seers have been able to give us their vision, notwithstanding the stern necessity of earning a living amid neglect and ridicule, they will be better able to do it in circumstances where their bread shall be given them and their water shall be sure. Granted that the child of genius must choose his vocation like other people; granted that no one sees his greatness; granted that he makes a poor shoemaker or tailor, it will still be true that he has more leisure than of old to listen for the Divine voice, and that 
he need not go hungry. But if, as will often happen, the responsible guardians of public interest hear of the work of a youthful Handel or Murillo, it will be their duty and their wisdom to encourage the gift that is in him, and place him where it can grow without being exposed to the chill blasts of discouragement and misfortune. And in all the recognised departments of the national life where the scholar, poet, thinker, and patient researcher are wanted, time and opportunity will be given them. Their work will not be sawn off in lengths, but judged by another standard.

Some of the steps now being taken towards the socialised State. - In what has now been said the critical reader may see only the profitless attempt to sketch an Utopia, which was expressly disowned at the beginning of this chapter. But I think it can be shown that it is, after all, only a reading of the future in the light of tendencies already at work. Who will deny that wealth means power over life, and that combination is necessary to the fullest development of that power, whether moral or spiritual? Who will deny that under our existing economic system, or want of system, the individuality of the average man is cribbed, cabined, and confined? If combination of material resources were carried out on a national scale, would not the result mean deliverance from anxiety and a wider life for all instead of only for the few? But, apart from all theorising, this is exactly the way things are tending 
now. The provision of old age pensions is one step in the process. Free meals for school children is another. Free education we already have, but it will have to become far more efficient than it is, especially in the provision of technical instruction; the great existing hindrance to a satisfactory settlement of our outstanding problems under this head is the religious imbroglio, and the sooner we can get rid of it the better. The Employers' Liability Acts are an instalment of what is to come when the industrial community is the sole employer. Is it not true that public expenditure tends to increase and private expenditure to decrease? The outcry about rising rates and an advancing income tax shows that the desire for retrenchment is futile; and it ought to be futile, for a nation is richer by what it wisely spends communally, and poorer by all the cost of private indulgence. Every year the opportunities of travel, culture, and enjoyment, which formerly were the special preserve of the rich, are being made more and more accessible to the general public, always by co-operation or communal enterprise. Every year the purchasing power of large incomes proportionately declines; every year the State is levying a larger toll upon the material possessions a man leaves behind him when he dies, or the income he enjoys, without having earned it, while he lives. Every year the community is appropriating more of the proceeds of rent and interest and applying them to public uses. What can be 
the outcome of all this but the realisation of an industrial order in which co-operative production and co-operative consumption will go hand in hand, and the resultant output of wealth be enormously increased? Every year the State or the local authorities are increasing the number of organisations in which direct employment has to be given to thousands of workmen who receive a standard wage. It will only be a matter of time before a standard wage is insisted upon in all employments; and not so very much longer before all employments will be brought directly under communal control, either by the taking over of big concerns or by the addition of departments to the communal enterprises already existing. Thus we have, or shall have, municipal dwelling-houses, bakeries, steamboats, fire insurance, hospitals, slaughter-houses, pawnshops, gasworks, electric works, tramways, milk distribution, laundries, and even nurseries. Where is this to stop? Why should it stop anywhere so long as it can be advantageously increased? and what can create the demand for commodities communally produced except public opinion? We may be quite sure that as soon as any special form of enterprise, even fruit selling or bicycle making, begins to be an interest in which the public as a whole is directly concerned, it will be taken out of private hands; in time there will not be much left for private capital to do, and not much capital to do it with. With education, housing, child-feeding, the minimum wage, and 
old age provided for, we have the foundation of a perfectly socialised State - and all these are here now, in embryo at least. Then indeed we can begin to hope for such a raising of the general level of culture and refinement that what is now the exception may become the common standard of attainment in a happy and enlightened fellowship of service. Not until our productive activities have become fully socialised will individual liberty in the fullest sense become possible. 


\section{CHAPTER $\mathrm{X}$}

THE SOCIALISED STATE: II

Socialism and the family. - In the survey we have now been making of the probable effects of the socialising of wealth and labour nothing has been said about certain outstanding problems in which human nature has as yet shown itself stronger than any code of regulations, however stringent. Of these, the most intractable and delicate is that of the relations of the sexes, with all the far-reaching consequences involved therein. It is repeatedly laid to the charge of Socialism that it involves free love, which is, I suppose, a euphemism for free lust. This charge, if true, would entirely justify the further assertion, so commonly made, that Socialism means the break-up of the family on which our western civilisation rests. It would be useless to give a flat denial to these charges, for there is a small modicum of truth in them of which Socialists have no need to be ashamed. But that modicum of truth must not be confounded with the extreme utterances of the so-called Socialists who are really sexual anarchists. Of these there are very few, and not only do they not represent the movement as a whole, but the movement as a whole would repudiate them 
entirely. Socialism ought no more to be judged by the eccentricities of a very few amongst its professed adherents than any other system, religious, moral, or political. Christianity has produced exponents of free love, and continues to do so from time to time, but no sane person would think of estimating Christianity by the utterances of such individuals. When I speak, therefore, of the modicum of truth which underlies the charge that Socialism would interfere with marriage and the family 1 do not mean that the Socialist movement shows any indication whatever of a tendency to encourage promiscuity in sex relations. What I do mean is that Socialism will do away with the unfair predominance of one sex, insist on the absolute equality of men and women before the law, and hold the parent responsible in a much higher degree than at present, as the trustee of the State, for the welfare of the child. The autocratic and proprietorial paternal government of the family is already having inroads made upon it, and in the socialised State those inroads would be greater still. But Socialism will continue to regard the highest form of sex relationship as the union of one man and one woman for life on the basis of mutual respect and affection; and it will so frame the regulations relating to marriage and divorce as to facilitate that end and remove all artificial hindrances from its realisation.

Prostitution. - For what have we at present? Let those who profess to tremble at the iconoclastic 
proposals of Socialism face the facts fairly and squarely. Modern Christian civilisation has to pay a dreadful price for the outward integrity of its family life. In every great city of the western world there exists a class of women who live by hiring themselves to men whom they do not know and have never previously seen, and with whom their only bond is that of lust and lucre. In London alone it is estimated that the number of these women amounts to scores of thousands. Everybody knows this, and, in polite society, pretends not to know it. The women of Christendom are thus divided into two classes, those who have a status and those who have none. The former shrink in horror from the latter, reprobate them, or ignore their existence; the men regard the one class as their friends and companions, the other as the slaves of their passions. People will tell you frankly that prostitution is a necessity as human nature is at present, a disagreeable necessity, but one of the hard animal facts of life that cannot be got rid of. Is this true? I am quite sure it is not, and I hope to be able to show that Socialism has a remedy to offer for this evil also.

The status of respectable women. - But before going on to examine the causes which necessitate the remedy, let us frankly recognise that the condition even of respectable womanhood cannot be deemed satisfactory under our present system. There is widespread misery within the marriage tie. 
Women are largely at the mercy of men, and have far less freedom of action and range of interest as a rule. The ideal marriage is a rarity, and it is unquestionable that money enters into the matter of obtaining a husband even in the most respectable society. Too frequently the fashionable bride sells herself as really as the unfortunate. Probably this assertion ought to be qualified by adding that the desire for a husband and a home are essentially worthier than the mere desire for money and excitement, and more consistent with self-respect. But if all the heart-burnings, incompatibilities, petty miseries and scandals which are the result of marriages entered into for the sake of money could be eliminated, the sad total would be appreciably reduced. Would they be so frequent in a socialised State? Again I think not; and the remedy for prostitution would not be ineffective even in the lessening of the likelihood of loveless marriages.

The question of female labour. - Then take the large number of cases in which, owing to various reasons, women are unable to find husbands. The mild contempt with which the single woman used to be regarded was different from that bestowed upon her fallen sister, but was not less real. Of late years, however, a change has been coming over modern society which is doing something to improve the status of unmarried women; they are being better educated and coming out into the world fully equipped to earn their own living. This is giving 
us a new type, the type of woman who is not in a hurry to tie herself up to the comparatively narrow existence of domestic drudgery; she feels more independent and acts accordingly. But this very fact gives rise to fresh complications; she is ousting the man from fields of employment which he has hitherto considered entirely his own, and there is no saying where this tendency is going to stop. She is proving herself just as capable as her former lord and master of holding her own in the professions and trades, except where sheer manual strength is the desideratum. But, so far, she is cheaper, for she has not a family to support, and indirectly this is a cause of much hardship; the displacement of male by female labour is bound to mean under present conditions the lowering of the standard of living among workers generally, unless measures can be taken to see that it does not.

Private property at the bottom of the disabilities of women. - These are only the more prominent aspects of an exceedingly intricate and many-sided problem. What I now wish to show is that the question of private property is always mixed up with it, and that there can be no satisfactory solution outside Socialism. For the truth is that even this nauseous problem of prostitution has an economic root; it springs from the economic dependence of women upon men. This becomes obvious the moment we ask ourselves why it is that male prostitution would not answer in such a civilisation 
as ours. For untold centuries the woman has been not only the dependent, but more or less the private property of the man. In spite of the glamour cast by love upon the relations of the sexes, this one hard basal fact obtrudes itself whenever wè begin to probe things, and ask the reason why women feel themselves to be at a disadvantage as compared with the stronger sex. It is because the man owns what there is to own; he used to own the woman out and out; now he only owns her indirectly, as it were. We are so accustomed to this state of things that we hardly ever pause to ask ourselves whether it is the best that could be devised, or even whether it bears hardly upon the less privileged members of the less privileged sex. The number of women of independent means is very small in this or any other country. The overwhelming majority of the sex are dependent upon their menfolk for everything worth having in life, and in return they have to render services of various kinds which are no light matter. The daughter in the family finds that she has to take a subordinate position to the brother, look up to him, and care for his creature comforts. If she be high enough up the social scale to be able to avoid this duty, she generally becomes a sort of idle parasite upon the family resources, flitting like a butterfly from one trifling means of enjoyment to another. There is nothing much more aimless than the life of a young woman of fairly good position who has not 
found some purpose of her own in life; the average comfortable middle-class family is one in which all the boys seek a profession as a matter of course, while the girls waste their time hanging about the house or paying visits. When these become wives their behaviour is probably not very different, so long as their husbands can afford to keep them in such a position that they are not obliged to do any menial work; they seldom have, or expect to have, work of their own comparable to that of the husband. They bear his children and preside at his table, but that is about all; they are expected to be ornamental, and consequently they spend a large proportion of their waking hours in fitting themselves to be as ornamental as possible. Thus, the basal reason for the fact that the papers which are read by women have to contain so much about dress and weddings is just this hard economic necessity for pleasing the man, who has the means of giving or withholding the good things of life.

Man is woman's capitalist. - Lower down the social scale the case becomes still plainer. The working-man's wife is a drudge. Her lord may complain of a ten hours' working day; hers is much longer. If poverty forces her into the labour market itself, she finds herself at an overwhelming disadvantage. If the male wage-earner is more or less at the mercy of the capitalist, the female wage-earner is more or less at the mercy of both. Taking the matter through and through, it may be said, without 
much fear of contradiction, that the vast majority of the women of Christendom stand in such a relation to the male sex that the latter may be regarded as their capitalist; they have little or no access to the sources of production, and therefore they have to remain in a position of dependence. At the best this position of dependence is one of respected inferiority, at the worst it is hell.

Private property and prostitution. - If now, with this broad general fact in mind, we ask ourselves where prostitution comes from, not to speak of the many other disabilities of which women are becoming increasingly conscious, we need not long remain in doubt about the answer. Women are driven to prostitution by the fact that it is so difficult to get money in any other way, and money is the one means which will open the door to comfort and enjoyment. The life of the average woman is narrow and dull compared with that of the man in the same station; she likes excitement and change just as much as he does, but the necessary material equipment does not so easily come her way. Here and there we may find a woman who has adopted this dreadful trade through sheer force of animal passion, but these can only be a few out of the teeming thousands in the ranks of ill fame. The truth is, though it may not be pleasant to face it, that many of our notions about women and the family have had a not too creditable origin. Why do we penalise a woman more than a man for sur- 
rendering her virginity outside wedlock? If we get far enough back into the dim shades of history we shall find that it is due to male selfishness. Why do we discriminate against the unfaithful wife as compared with the unfaithful husband, as is the case with our divorce law at present? The real reason is that primitive man did not wish to have to work to support other. people's children, and he still wants to make sure that this undesirable task shall not be thrust upon him. The plain result is that we take care to have a class of women of whose good behaviour we can feel fairly secure, and another class of whom similar good behaviour is not expected. Man demands both; hence he pays for both, and hedges the former class round with so many pains and penalties that if an unfortunate individual offends he forthwith does his best to thrust her into the latter. Our practice in this matter is of such long standing that we have persuaded ourselves that it is "moral" and "Christian." As a matter of fact it is the meanest, shabbiest, most selfish plan ever devised by selfish man for keeping his hold on his private property-woman. We have so trained the whole female sex to take our point of view in this matter that our best allies against female offenders are women themselves. The ordinary woman without private means or a footing in the professional or business world has before her a kind of Hobson's choice - reputable or disreputable dependence upon the male sex. 
Comparative uselessness of rescue work. - All this shows how futile are the various efforts put forth at the present time to deal with the social evil, as it is conventionally called. It is indeed the social evil in a sense unguessed by most of those who call it such. Religious organisations send out hosts of pure and good women to win, if possible, their fallen sisters back to rectitude; and "vigilance" societies prosecute the harpies who beguile innocent girls into this mode of life. How many do they save? I am afraid it must be confessed that they make no more impression upon the gigantic total of misery and despair due to this cause than charitable organisations make upon the problem of chronic poverty. For every victim lifted out of one end of the sewer a fresh one falls in at the other. Police regulations may drive the traffic underground, but they cannot destroy it so long as the conditions continue which have made it possible in the first instance. What is wanted is a radical change in the status of women, and that change is already on the way. There is no juster or more urgent cause claiming the attention of the civilised world to-day than that of female suffrage, and there can be no ground for opposing it other than the purely selfish one that its triumph would mean the abolition of the privileged position of the man. In this Socialism sees with clear vision, and maintains, in the spirit of the Founder of Christianity, that offence against the conventional rules of 
sex-morality is not the worst kind of offence. No one can read the gospels without being impressed with the gentleness of Jesus to erring women. Was not that gentleness due to His perception of the fact that they were unfairly punished as compared with their betrayers? Did He not pity their comparative helplessness in the hands of men? Socialism, therefore, is closely in accord with the spirit of the true Christianity when it insists not only that men and women should be absolutely equal before the law and enjoy equal rights of citizenship, but that the present economic dependence of one sex upon the other should come to an end. To gain the former would in time secure the latter, for women know well enough what they want, when once they have felt, as in increasing numbers they are coming to feel, how heavily they are handicapped in the struggle for a living in having to compete with men. In all the more desirable fields of service men retain the monopoly, and either exclude women or admit them grudgingly. Give women political power, and in the industrial reorganisation which is at hand they will claim and receive their due share. Every woman ought to have as full an opportunity as the man of serving society at large and receiving her share of the communal income. There is hardly any calling in which she is not already the proved equal of the man when put to the test; but, granted that there will always be special avocations in which 
the one sex will outshine the other, there is no reason in common justice or in common sense why one sex should have to depend upon the other for permission to enter such a field or for the means of subsistence when in it. Every girl should be as thoroughly educated, even technically, as every boy, and every female citizen in a socialised State should be entitled to do her share in the production of the national wealth and to receive her appropriate share of the output. That highest privilege of womankind, maternity, ought not to be excluded from this provision. In any properly organised community the mother should be entitled to material support from the communal stores in accordance with her needs at the child-bearing period. When one thinks of the conditions under which children are being brought into the world to-day in povertystricken homes one can but feel that the truest economy in the long run in national efficiency and productive power would be the economy that put the mothers of our future citizens beyond all fear of want. I have shown in previous chapters that even now this could be effected if the national wealth were properly distributed; even now none of England's mothers would need to want if their fair share of the national income were apportioned to them. What would it be under a system in which industry were so organised as to educe and combine the best talent of the many millions of women in this country in addition to the men? 
At present this is a vast unworked field. Unremunerative toil in precarious positions, where the little that is earned has to be eked out by the wages of shame, ought to be rendered impossible for ever. Neither should there be any more fashionable idlers; woman ought to know the joy of serving the common good as much as man, and should have no more reason for trifling with life than he. ${ }^{1}$

Marriage under Socialism. - How will this affect the marriage bond? Well, it will not be a bond. I see no necessity for reserve on this subject, and the more plainly Christian Socialists can speak out the better. Our present laws relating to marriage and divorce are anomalous and unjust, and the worst of the situation is the fact that ecclesiastical prejudice is the great stumbling-block in the way of change for the better. A good example of the kind of irrational prejudice which exists on this subject is furnished by the behaviour of many of our bishops and clergy at the present moment in regard to marriage with a deceased wife's sister. Their reason for refusing to solemnise such marriages on the ground that they are an offence against Canon law is the less understandable when we realise that the very same Canon law is against the clergy marrying at all! Surely it is time that such obscurantism were made to cease from its very absurdity.

${ }^{1}$ The standard work on this phase of our subject is "Women and Economics," by Charlotte Perkins Gilman (Putnam's). 
Probably we shall find that the clergy will fight tooth and nail against every proposal towards affording relief to those unfortunate persons whom marriage has placed in an intolerable position. The law relating to marriage will have to be made stricter in the time to come, and that relating to divorce will have to be relaxed and equalised. Why in the world should a good woman remain tied all her life to a criminal husband? At present her only chance of relief is that he may have been both adulterous and cruel. Even then the relief is a doubtful benefit if it involves the risk of starvation. Many a woman would rather put up with the humiliation of a husband's evil conduct than expose her children to the danger of having to go without bread by separating from him; her legal claim upon his purse is her sole guarantee that they will not have to suffer, so she struggles on and bears it. But what would she do if she could be freed from such a bondage without fear for her own or her children's future? Then again, as things are, the partial relief of a judicial separation in the case of an unhappy marriage is a direct incentive to immorality. No sacro-sanct considerations should be allowed to stand in the way of such necessary alteration of the existing law as would prevent the enormous amount of domestic unhappiness which exists at present because of the difficulty of obtaining release from an unworthy partner. Infidelity to the marriage vow ought to be enough to procure divorce 
if the case were proved by either party; and, once all economic considerations were eliminated from the question of marriage, there would no longer be any reason why the law should compel any one to continue in conjugal relations with a person whose conduct was a constant source of humiliation and distress. The emancipation of women from economic dependence upon men would render many of the latter more careful of their conduct and less heedless of the consequences.

The family of the future. - Nor is it at all probable that such a readjustment of the relations between the sexes would lead to the break-up of the family. The forces which hold the family together are not merely economic or magisterial; if they were we might indeed fear for the future of society. The institution which has to be maintained by restrictive enactments is not on a sound basis, and cannot be trusted to be of permanent benefit to the race. It sometimes seems to me that those who resist legal changes are in danger of forgetting this. What earthly good does it do to hold men and women together or safeguard the integrity of the family by the power of the law court? The object of the law should be to safeguard the weak, and, in a state of society where the economic basis of marriage was different, that duty would not need to be exercised to the same extent as at present. But a new set of duties would emerge. The State would insist on the regulation of marriages to a 
greater extent than is now dreamed of, and such regulation would be justified on the ground that society as a whole had a direct interest in the sort of children that were likely to be brought into the world as the result of such marriages. This is a point of view which is at present hardly ever taken. How far it could be pressed must, for a long while to come, remain a matter of opinion. Those who burden the community with illegitimate children, or who wantonly offend against the marriage vow, are dangerous to the common weal, and should be more severely dealt with than at present. The rights of citizenship should be withheld from all who trifle with its responsibilities in any such way, and there should be no discrimination between the sexes in regard to the penalty inflicted. That these penalties would not be inoperative is proved by the greater continence of the female sex at the present time; men could exercise just as much self-restraint if they had the same well-founded fear of consequences. There would be no need to safeguard the integrity of the family; it would safeguard itself. It is not to be supposed that, while human nature remains what it is, the one man will cease to seek out the one woman with whom he can be happiest and join hands with her in solemn wedlock for the making of a home. The coming of the child is, in addition to a mutually respecting love, the most powerful force that could be imagined for keeping the home together. That 
man and woman and child should continue to love each other, and to regard home as the sweetest place on earth, will only be what we should expect in a state of society wherein the general level of culture and intelligence would be much higher than at present, and from which all artificial restraints would be removed. It is not law but love that makes home; and greater freedom and independence on the part of the wife and mother, and greater sense of responsibility to the State on the part of the husband and father, will never tend to lessen love, but rather to increase it.
"The love that follows fain
Will never its faith betray;
But the faith that is held in a chain
Will never be found again
If a single link give way."

The Poor Law. - The mention of pauperism opens up another phase of our general subject in which public opinion is nearly ripe for strong action. Our present Poor Law system is a scandal. In an efficiently socialised State we should not need a Poor Law; its presence is a testimony to the baleful effects of Individualism. But, even for its present purpose, it is both wasteful and ineffective. It spends far too much money on officialism, and far too little in ameliorating the lot of the deserving poor. Indeed, it is difficult to see how the deserving poor could really be helped under such a system, 
a system which is humiliating and degrading to the self-respecting recipient of relief. It is only as a last resort that the really industrious poor are forced into the workhouse in their declining years. To bring up children in such an atmosphere is monstrous. One welcome sign of the times is the pressure which is being brought to bear upon local authorities to have indigent orphans and the children of pauper parents educated along with other children in the ordinary public school. But, in order to strike at the pauper system, society will have to provide against unemployment on the one hand and the poverty of old age on the other. Both these desirable innovations are already within measurable distance, and are receiving support from many persons who would not call themselves Socialists. I have already indicated the principle of action by which unemployment could be dealt with, namely, the provision of works of public utility which could stop or go on according to the demand for labour in the several trades. In the socialised State such fluctuation in demand would be certain to continue, though not to the same degree as at present, owing to the comparative absence of haphazard production. When once we get old age pensions of an amount sufficient to maintain the recipient in a fair standard of comfort, we shall have struck at the root of most that makes for pauperism. The class of the unemployed is always tending to produce the unemployable, because of the gradual lowering of the 
standard of physical efficiency in those who fall into it, as well as the encouragement of habits of idleness and unthriftiness; meet the problem at the fountain-head, and we should have dammed up one of the most prolific of the sources of pauperism. Outside these two classes of the aged poor and the unemployed we have the class of the habitual criminal and idler; the place for these is not the same institution as the general worker, but a penal habitation, which they would learn to dread even more than they dread the semi-penal regulations of the workhouse now. In the socialised State there would be no excuse for such persons. How it is that we have gone on so long without attempting to discriminate between the unfortunate worker and the habitual idler is one of the mysteries of our civilised procedure. I have not mentioned the sick, because in any thoroughly organised State the national hospitals would not maintain a precarious existence by voluntary contributions as now, but would come upon public funds and be publicly administered, like other departments of communal service.

The public house. - There remains the publichouse. Extreme temperance reformers need not imagine that they are ever going to abolish the public-house; no one can abolish it. It meets a need which will be as urgently felt in the future as in the present. But at present, to employ an Irishism, the public-house is not a public-house; it is 
a private house, publicly used, but privately managed and run for private profit. Probably most of the evils associated with it are due to this fact; it is to the interest of the liquor seller to get people to drink as much as possible, and, as long as that is so, legal restrictions and regulations will continue to be evaded. There is only one remedy which a Socialist can consistently propose, and that is that the public-house should be a public-house; the ownership and management should be taken completely out of private hands and vested in the community for public convenience. If this were done, there would be no reason why the public-house as a social centre should be less reputable than the Post Office or the Town Hall for their respective purposes. The sale of intoxicants might even be prohibited if public opinion were ripe for it.

Towards the higher life. - But these are only administrative changes which are already being effectively agitated. In stating them I have no other purpose in view than to show that they are practical, and consistent with the principles of Socialism and Christianity. If what has been said in the latter part of this book commends itself to the intelligence and moral sense of the reader, let me ask him to consider its connection with the aim and purpose of Jesus of Nazareth. Neither our Lord nor His followers thought of material good as more than a means to an end. What they looked forward to was the reign of 
peace and good-will in an ideal world in which every individual would be the servant of all. In a series of aphorisms Jesus insisted upon this so strongly that His words may fairly be regarded as the spiritual presentation of the aims of modern Socialism. The spiritual ideal of Jesus made the fullest demand upon the individual, but always for the sake of society. Losing the life to find it meant with Him nothing other than finding one's true joy in the service of the common good. Does the present organisation of society permit such a motive to operate unhindered? Is it true that the average man feels himself able to express his very best in the service of the whole? Is it not rather the truth that in most of us there are possibilities dammed up which will never find expression so long as the present struggle for existence continues? How many of us have leisure and opportunity to be to the world what we sometimes dream we might have been? What Gray said of the country churchyard could be said of the workhouse and the slum -

"Some mute, inglorious Milton here may rest;

Some Cromwell, guiltless of his country's blood."

In our best and most generous moments would we not all say that it were better for the world, better for the sum of human happiness, that the fetters should be struck away which prevent the 
Milton from singing and the Cromwell from leading? Unquestionably we should; the only thing about which we should disagree would be whether, considered in the cold light of reason, the change were practicable, and could be executed without danger of chaos and ruin.

Well, it would be a great deal to have got even as far as this, to see clearly what is wanted and to desire that it should be realised. What is wanted, after all, is only what a few people wanted so earnestly twenty centuries ago that when they listened to the greatest Teacher the world has ever had they began to believe it possible; and, in later days, when $\mathrm{He}$ was gone from them, wove the garland of their gratitude around His very cradle, and uttered their ideal in the angel-song: "Glory to God in the highest, and on earth peace, good will amongst men."

The utmost for the whole. - This is precisely what Socialism is aiming at now, and I call upon all who reverence the name of the great Master of mankind to aid in the endeavour to realise it. It means the bringing of a higher set of motives into play. To a certain extent these higher motives are operating now, and nowhere more than in the lives of the poor and unfortunate, but their expression is hampered and crushed by the grim necessity of fighting for a footing in life. I mean the motives of generosity, comradeship, public spirit, and the joy of self-giving 
for the common good. We could appeal with confidence to these motives, for they are the deepest and noblest in human nature; they are that which stamp it divine. It is a tribute to our common humanity that under such sordid and evil conditions as those which govern our social life to-day we are able to witness these nobler motives at work even now. When, for example, a man of culture and genius like John Ruskin writes a book of the order of "Unto This Last," his motive is not money-getting, but the desire of service. Happily he did not need to take the money motive into consideration. When a great artist like G. F. Watts paints a great picture, he does so without any desire for material reward, but only with the object of uttering his best and highest for the enrichment of the common life. He would tell you that no true artist should ever be dominated by any other motive; if he has to descend to producing in order to sell, the quality of his work must necessarily suffer. When a great statesman like Lord Salisbury spends himself day and night in the public service, his chiefest reward is not that he has won a certain position and means to keep it, come what may, but that as the trustee of the public well-being he has succeeded in achieving something, the benefits of which will be even more evident in the future than in the present. When an hour of national danger strikes, every 
free man rallies to the flag, not for pay, but for patriotism. In all these various ways, and in others too numerous to mention, we are ever recognising that the highest aim for the individual is the impersonal one, and we see it at its best when it involves not merely self-sacrifice, but self-expression. Why should ordinary everyday life, especially that overwhelmingly large part of it in which men are engaged in earning a livelihood, be excepted from the operation of this principle? Why should it not hold as good for our industrial life as for anything else? We only need to ask ourselves the question in order to see whither the answer would lead us. It is because it stands for this great spiritual principle that Socialism is making its appeal so powerfully to the conscience and heart of the rising generation. But is not this the message of Jesus, not in detail, but in principle? It is not the whole Gospel, for it does not profess any concern for the destiny of the individual in those higher spheres which, as most of us believe, and evidence is beginning to demonstrate, await us in the regions beyond the change called death. But, even in primitive Christianity, immortal life, as we have seen, was not quite what it is to modern thought and expectation; and yet it was always assumed as the most potent reason for seeking to help mankind here. That reason holds just as good to-day. Salvation must include the develop- 
ment of the whole man. If he be ignorant and degraded here, ignorant and degraded he will begin on the further side of death; and I can imagine no motive so strong, in the effort to realise the Kingdom of God on earth, as the conviction that because the individual soul is immortal it should be helped to find the fullest self-expression here in order that it may begin on a higher level elsewhere. It is this spiritual end which should bid us welcome the efforts of Socialism to ameliorate the lot of the masses and make a true individuality possible for each and all.

It goes without saying that Socialism does not look for a statical condition of society, nor does it profess to be able to cure all the ills that flesh is heir to. Pain and sorrow will probably always find a place in earthly life, but there is no reason why we should take for granted that they will always be the shadow upon life that they are now. The normal life should be the life of brightness and joy. And this is the life which is in the gift of that greater day which is already on the horizon, when the motives of greed and fear will have passed away for ever by the coming of a social order in which there shall no longer be any room for them. Let us join hands and hearts in the endeavour to hasten that day by every means in our power. The rich man will lose nothing that he has now, and he will gain immeasurably in the joy of seeing everywhere 
284 CHRISTIANITY AND THE SOCIAL ORDER

around him a contented and happy people, his brothers and equals. To the poor it will mean the fulfilment of the promise uttered in the name of Jesus: "I am come that they might have life and that they might have it more abundantly." To all alike it will be the fulfilment of the prayer of Jesus, "That they all may be one." 





$N T$ 

RETURN TO the circulation desk of any University of California Library

or to the

NORTHERN REGIONAL LIBRARY FACILITY

Bldg. 400, Richmond Field Station

University of California

Richmond, CA 94804-4698

ALL BOOKS MAY BE RECALLED AFTER 7 DAYS

- 2-month loans may be renewed by calling (510) 642-6753

- 1-year loans may be recharged by bringing books to NRLF

- Renewals and recharges may be made 4 days prior to due date

\section{DUE AS STAMPED BELOW}

JUL 142004 


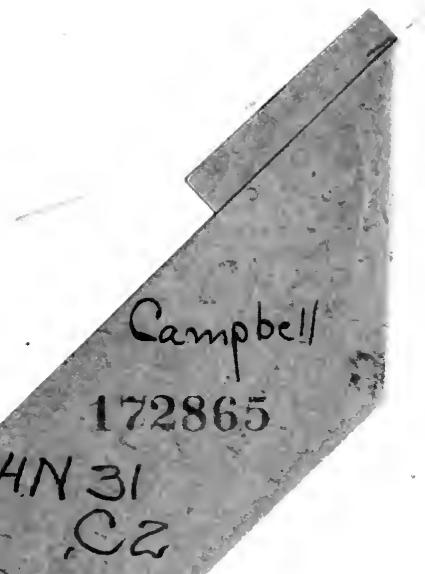

Campbell 172865

\section{HN 31} $+2$ 
